Direção Exiltorial

Prof. ${ }^{\circ}$ Dr. Adriano Mesquita Soares

Organizadora

Prof. ${ }^{a}$ Dr. ${ }^{a}$ Andreia Antunes da Luz

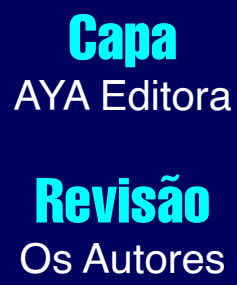

Excerutiva de Negócios

Ana Lucia Ribeiro Soares

Produção Eilitorial

AYA Editora

Imagens de Gapa

br.freepik.com

Área do Gonhecimento

Engenharias

\section{Eonselho Eulitorial}

Prof. ${ }^{\circ}$ Dr. Aknaton Toczek Souza

Centro Universitário Santa Amélia

Prof. ${ }^{a}$ Dr. ${ }^{a}$ Andreia Antunes da Luz

Faculdade Sagrada Família

Prof. ${ }^{\circ}$ Dr. Carlos López Noriega

Universidade São Judas Tadeu e Lab. Biomecatrônica -

Poli - USP

Prof. ${ }^{\circ}$ Me. Clécio Danilo Dias da Silva

Centro Universitário FACEX

Prof. ${ }^{a}$ Dr. ${ }^{a}$ Daiane Maria De Genaro Chiroli

Universidade Tecnológica Federal do Paraná

Prof. ${ }^{a}$ Dr. ${ }^{a}$ Déborah Aparecida Souza dos Reis

Universidade do Estado de Minas Gerais

Prof. ${ }^{a}$ Dr. ${ }^{a}$ Eliana Leal Ferreira Hellvig

Universidade Federal do Paraná

Prof. ${ }^{\circ}$ Dr. Gilberto Zammarv

Universidade Tecnológica Federal do Paraná

Prof. ${ }^{a}$ Dr. $^{a}$ Ingridi Vargas Bortolaso

Universidade de Santa Cruz do Sul

Prof. ${ }^{a}$ Ma. Jaqueline Fonseca Rodrigues

Faculdade Sagrada Família

Prof. ${ }^{\circ}$ Dr. João Luiz Kovaleski

Universidade Tecnológica Federal do Paraná

Prof. ${ }^{\circ}$ Me. Jorge Soistak

Faculdade Sagrada Família

Prof. ${ }^{\circ}$ Me. José Henrique de Goes

Centro Universitário Santa Amélia

Prof. ${ }^{a}$ Dr. ${ }^{a}$ Leozenir Mendes Betim

Faculdade Sagrada Família e Centro de Ensino

Superior dos Campos Gerais

Prof. ${ }^{a}$ Ma. Lucimara Glap

Faculdade Santana
Prof. ${ }^{\circ}$ Dr. Luiz Flávio Arreguy Maia-Filho

Universidade Federal Rural de Pernambuco

Prof. ${ }^{\circ}$ Me. Luiz Henrique Domingues

Universidade Norte do Paraná

Prof. ${ }^{\circ}$ Dr. Marcos Pereira dos Santos

Faculdade Rachel de Queiroz

Prof. ${ }^{\circ}$ Me. Myller Augusto Santos Gomes

Universidade Estadual do Centro-Oeste

Prof. ${ }^{a}$ Dr. ${ }^{a}$ Pauline Balabuch

Faculdade Sagrada Família

Prof. ${ }^{\circ}$ Me. Pedro Fauth Manhães Miranda

Centro Universitário Santa Amélia

Prof. ${ }^{a}$ Dr. ${ }^{a}$ Regina Negri Pagani

Universidade Tecnológica Federal do Paraná

Prof. ${ }^{a}$ Ma. Rosângela de França Bail

Centro de Ensino Superior dos Campos Gerais

Prof. ${ }^{\circ}$ Dr. Rudy de Barros Ahrens

Faculdade Sagrada Família

Prof. ${ }^{\circ}$ Dr. Saulo Cerqueira de Aguiar Soares

Universidade Federal do Piaú

Prof. ${ }^{a}$ Ma. Silvia Ap ${ }^{\text {a }}$ Medeiros Rodrigues

Faculdade Sagrada Família

Prof. ${ }^{a}$ Dr. ${ }^{a}$ Silvia Gaia

Universidade Tecnológica Federal do Paraná

Prof. ${ }^{a}$ Dr. ${ }^{a}$ Sueli de Fátima de Oliveira Miranda

Santos

Universidade Tecnológica Federal do Paraná

Prof. ${ }^{a}$ Dr. ${ }^{a}$ Thaisa Rodrigues

Instituto Federal de Santa Catarina 
() 2021 - AYA Editora - O conteúdo deste Livro foi enviado pelos autores para publicação de acesso aberto, sob os termos e condições da Licença de Atribuição Creative Commons 4.0 Internacional (CC BY 4.0). As ilustrações e demais informações contidas desta obra são integralmente de responsabilidade de seus autores.

T757 Tópicos especiais em engenharia de produção 3. / Andreia Antunes da Luz (organizadora). Ponta Grossa: Aya, 2021. 86 p. -- ISBN: 978-6588580-26-4

Inclui biografia

Inclui índice

Formato: PDF

Requisitos de sistema: Adobe Acrobat Reader.

Modo de acesso: World Wide Web.

DOI 10.47573/aya.88580.2.20

1. Engenharia de produção. 2. Administração da produção. 3. Mercado de trabalho. 4. Pandemias. 5. Infecções por coronavírus. 6. Pesquisa operacional. I. Luz, Andréia Antunes da. II. Titulo.

CDD: 658.5

Ficha catalográfica elaborada pela bibliotecária Bruna Cristina Bonini - CRB 9/1347

\author{
International Scientific Journals Publicações \\ de Periódicos e Editora EIRELI \\ AYA Editora@ \\ CNPJ: $\quad 36.140 .631 / 0001-53$ \\ Fone: $\quad+5542$ 3086-3131 \\ E-mail: contato@ayaeditora.com.br \\ Site: $\quad$ https://ayaeditora.com.br \\ Endereço: Rua João Rabello Coutinho, 557 \\ Ponta Grossa - Paraná - Brasil \\ 84.071-150
}




\section{Apresentação}

As organizações em tempo de crise buscam ações de sustentabilidade e competitividade, a busca por inovações em processos e produtos, a aplicação de conhecimento, técnicas e ferramentas de gestão possibilitam produzir melhor e com menos recursos, como também melhorar o atendimento a clientes.

O atual cenário econômico evidencia a importância de acompanhar o ambiente e adaptar-se, o aprendizado contínuo é importante para estarmos atualizados e, assim, contribuir para a sustentabilidade das organizações.

Convido você a continuar avançando no aprendizado e conhecer este livro de Tópicos Especiais em Engenharia de Produção III, o qual, compartilha conhecimento de pesquisadores das Engenharia de Produção e áreas afins, este e Tópicos Especiais em Engenharia de Produção I e II, destinam-se a estudantes, professores e profissionais em atuação na Engenharia de Produção e áreas afins.

O livro está organizado em seis capítulos. O primeiro capítulo apresenta uma proposta de elaboração de um diagrama de decisão que permita classificar os itens de estoque de uma empresa do ramo de petróleo e gás. O capítulo segundo apresenta o quinto princípio econômico denominado o comércio é bom para todos e importante para o entendimento do comportamento dos agentes que atuam num sistema econômico sob um processo de equilíbrio espacial de preços. O terceiro apresenta uma revisão da literatura a respeito do modelo Drum-buffer-rope (DBR). Seguindo para o quarto capítulo podemos encontrar um modelo matemático de programação linear $(\mathrm{pl})$ para maximizar a lucratividade de uma área de cultivo de uvas e a produção de vinhos no município de Flores da Cunha, Rio Grande do Sul, finalizando com uma revisão sistemática de literatura de toda produção científica com conteúdos relacionados a inovação aberta e a economia circular do SIMPEP, de 2010 à 2019.

Desejo que esta obra contribua para o avanço do conhecimento e possam contribuir com a formação dos estudantes, professores e profissionais em atuação na Engenharia de Produção e áreas afins. Uma boa leitura!

Andreia Antunes da Luz 


\section{Sumário}

\section{1}

Classificação de itens em estoque a partir de diagrama de decisão e AHP

César Cardozo Amaral

DOI: 10.47573/aya.88580.2.20.1

02

"Trocar é bom": o princípio econômico descrito sob a noção de fronteira de possibilidades de produção. .20

Andre Menenguci Pires, Alexandre Manoel dos Santos, Mabel Camara de Araujo, Manoela Theodorovitz dos Santos, Sergio Fernando Mayerle

DOI: 10.47573/aya.88580.2.20.2

03

Revisão da literatura do modelo Drum-buffer-rope

Arthur Costa de Medeiros, Fernanda Heloah dos Santos Silva, Gabriel Nuno da Silva, Mariah Caroline Martins de Sousa e Fernanda Barreto de Almeida Rocha Mariz

DOI: 10.47573/aya.88580.2.20.3

04

Programação linear aplicada na maximização de lucro no cultivo de uvas

Andressa Manosso, Leonardo Scodro e Leandro Luís Corso

DOI: 10.47573/aya.88580.2.20.4 


\section{5}

Economia circular e inovação aberta nos anais do SIMPEP (20102019)

Claudia Maria Napolitano Sanchez Morasco e Vera Mariza Henriques de Miranda Costa DOI: 10.47573/aya.88580.2.20.5

06

Análise da vida profissional dos estudantes de uma IES em tempos de pandemia da COVID-19 ..........................................................................71

Thaís Helena Passucci Ambrosio e Claudia Maria Napolitano Sanchez Morasco

DOI: 10.47573/aya.88580.2.20.6

Organizadora .82

Índice Remissivo 83 


\section{Classificação de itens em estoque a partir de diagrama de decisão $\mathrm{E}$}

1100

\section{Classilication of items in stock from decision diagram and AHP}

César Cardozo Amaral Pontifício Universidade Católica - PUC - PUC-RIO

तथ

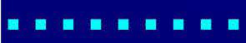

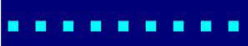

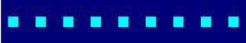

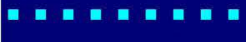

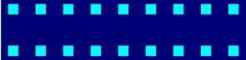
a

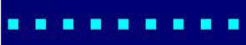

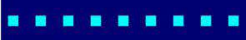

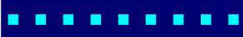
म +

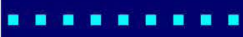
a

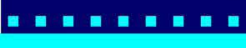

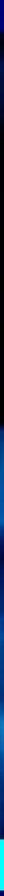


Este artigo propõe a elaboração de um diagrama de decisão que permita classificar os itens de estoque de uma empresa do ramo de petróleo e gás. Para tanto, faz uso da classificação $A B C$ e do método multicriterial AHP a fim de capturar as dimensões valor, volume e criticidade dos itens. Com isso, espera-se obter ganhos por meio da facilitação da implementação de melhorias na gestão de estoques a partir de ações conjuntas para os itens de mesma categoria. Como resultado, obteve-se a redução de faltas e excessos de estoque no sistema, contribuindo para a geração de valor financeiro para a empresa.

Palavras-chave: estoque. curva ABC. criticidade. AHP.

\section{Alistract}

This article proposes the drawing up of a decision diagram that allows to classify the stock items of a petroleum and gas company. For so much, it makes use of the ABC classification and the multicriterial AHP method in order to capture the value, volume and criticity of items dimensions. Therefore, it is expected to obtain gains by facilitating implementation of improvements in stock management from joint actions for items of the same category. As a result, a reduction of faults and stock executes in the system was obtained, contributing to the generation of financial value for the company.

Keywords: stock. curve ABC. criticity. AHP. 


\section{INTRODUÇÃO}

A definição de políticas de controle de estoques permite às empresas obterem reduções significativas de custos, seja por falta ou por excesso de materiais estocados (HOPP e SPEARMAN, 2008). Essa definição se torna ainda mais importante em empresas que precisem administrar materiais de diversas naturezas e cujo processo produtivo apresente características diferentes para cada unidade de negócio (PETTERSEN e SEGERSTEDT, 2008).

É nesse ambiente que se insere a empresa estudada neste artigo. Trata-se de uma empresa brasileira do ramo de Petróleo e Gás que possui milhões de itens em estoque, abrangendo de materiais químicos a produtos de administração predial, totalizando dezenas de bilhões de Reais estocados.

A empresa se depara com dificuldade se deve à diversidade de materiais existentes em estoque, bem como pelo fato de possuírem criticidades diferentes de acordo com a área de negócio em que são aplicados. Assim, a empresa acaba por adotar a mesma política para todos eles, sem diferencia-los quanto a valor, volume, unidade de negócio atendida ou tipo de material.

Isso acarreta em baixos de performance na gestão de estoques, o que pode ser constatado ao se analisar o último inventário da empresa, que aponta $35 \%(\mathrm{R} \$)$ de estoque excedente. Além disso, muitos materiais apresentam faltas no processo ( $25 \%$ do total de itens), acarretando em não atendimento das demandas, atrasos e paradas da produção.

Assim, a empresa depara-se com o seguinte problema: Como classificar os materiais da empresa nas diferentes áreas de negócio de forma que sejam capturadas as dimensões volume consumido, valor ( $R \$$ ) e criticidade?

Para responder essa questão, pretende-se elaborar um diagrama que permita classificar os materiais considerando essas dimensões e que, por sua vez, possa ser aplicado em cada área de negócio da empresa. Para tanto, utiliza-se a curva $A B C$ para volume (em unidades consumidas) e valor monetário em estoque, a fim de representar as dimensões volume e valor $(R \$)$, respectivamente. Para a criticidade dos materiais, aplica-se o método multicriterial Analytic Hierarchy Process (AHP) a fim de capturar os aspectos qualitativos e quantitativos das áreas de negócio quanto à criticidade.

Entretanto, em função do elevado número de itens, o estudo limitou-se a analisar os Stock Keep Units (SKU), reduzindo o quantitativo analisado. Além disso, por existirem diferentes áreas de negócio dentro da empresa, tornando a análise mais complexa em função da necessidade de envolver inúmeros stakeholders, definiu-se uma área para delimitar o escopo de atuação do estudo.

Como resultado deste trabalho espera-se que essa classificação permita criar classes de materiais similares quanto à volume consumido, valor $(R \$)$ e criticidade. Assim, a empresa pode adotar ações em gestão de estoques que sejam mais aderentes a natureza de uso desses materiais nas diferentes áreas de negócio, reduzindo custos a partir da otimização da quantidade estocada. 
Este artigo está dividido da seguinte maneira: na Seção 2 encontra-se o Referencial Teórico que aborda os principais conceitos utilizados no estudo. Na Seção 3, a metodologia adotada é abordada com maiores detalhes e a aplicação desta metodologia é descrita na Seção 4, onde também são discutidos os resultados. Por fim, na Seção 5, conclui-se o estudo destacando os pontos positivos e negativos, além de sugestões para futuros trabalhos.

\section{REFERENCIAL TEÓRICO}

\section{Classificação de materiais na Gestão de Estoques}

A classificação de materiais permita criar segmentos de produtos de tal forma que apresentem similaridades quanto às dimensões propostas. Dessa forma, pode-se obter ganhos pela ação conjunta abordando-se o todo ao invés do individual (MEHDIZADEH, 2019).

Assim, a agregação dos materiais em Stock Keep Units (SKU) auxilia nessa abordagem, agregando materiais para que sejam geridos como um só. Para isso, essa agregação deve ser realizada com base em parâmetros que permitam considerar os materiais como similares (MOLENEARS et al., 2011).

Dentre esses parâmetros, pode-se citar o volume consumido e o valor em estoque (monetário) como os mais largamente utilizados (SLACK; CHAMBERS e JOHNSTON, 2002). Entretanto, muitos autores têm destacado a importância de se incorporar outras características que sejam capazes de definir os materiais para além desses dois parâmetros citados (MOLENEARS et al., 2011; MEHDIZADEH, 2019; HAUTANIEMI e PIRTTILA, 1999).

Dessa forma, muitas empresas têm adotado outras características na classificação dos itens em estoque. Características como criticidade, importância, fornecedor e cliente são levadas em consideração nessa classificação, aumentando a complexidade da mesma, uma vez que se faz necessário considerar aspectos qualitativos (SLACK; CHAMBERS e JOHNSTON, 2002). Com isso, abordagens multicriteriais estão cada vez mais presentes em muitos trabalhos em classificação na Gestão de Estoques (MOLENEARS et al., 2011).

\section{Curva ABC}

A Curva ABC categoriza os itens em classes A, B e C de acordo com o critério escoIhido. Dentre esses critérios, o volume consumido ao longo de um determinado período ou o valor monetário dos itens costumam ser os mais utilizados na análise de itens em estoque num processo (SLACK; CHAMBERS e JOHNSTON, 2002).

Mehdizadeh (2019) e Hauaniemi et al. (1999) recomendam a Curva ABC como parâmetro para a definição da política de controle de estoque, uma vez que os itens $\mathrm{C}$ podem ser controlados por métodos mais simples, deixando os métodos mais complexos para os itens $A$.

Entretanto, muitos autores ressaltam que a escolha com base na Curva $A B C$ pode ser incompleta quando se pretende analisar a importância de um item para um processo. Isso se deve ao fato dessa ferramenta não capturar outros critérios que possam ser relevantes para essa análise (MEHDIZADEH, 2019; MOLENEARS et al., 2011; FLORES e 
WHYBARK, 1988; HAUTANIEMI e PIRTTILA, 1999).

Como exemplo desses critérios não capturados, pode-se citar a criticidade de um item para o processo (HAUTANIEMI e PIRTTILA, 1999). Esse item, numa classificação $A B C$, pode ser enquadrado como da classe $A$ em função do seu valor, mas pode ser pouco ou nada crítico ao processo.

Como forma de mitigar isso, muitos autores sugerem a adoção de métodos multicritérios, garantindo que outros critérios sejam considerados na análise (MEHDIZADEH, 2019; MOLENEARS et al., 2011; HAUTANIEMI e PIRTTILA, 1999).

\section{Analytic Hierarchy Process (AHP)}

Métodos multicritérios consistem em métodos capazes de capturar aspectos qualitativos ao se categorizar os itens analisados. Dessa forma, permitem análises mais consistentes, baseadas em critérios que não sejam puramente quantitativos e que incorporem a opinião de especialistas (MARINS; SOUZA e BARROS, 2009).

Dentre esses métodos, o Analytic Hierarchy Process (AHP) é um dos mais utilizados. Ele foi desenvolvido por Tomas L. Saaty no início da década de 70, tornando-se o método mais utilizado por analistas e pesquisadores na resolução de conflitos na tomada de decisão quando se deparam com multicritérios para essa decisão (MARINS; SOUZA e BARROS, 2009).

O AHP consiste em definir critérios e compará-los par a par, obtendo-se relações quantitativas entre eles. Assim, geram-se matrizes cujos vetores normalizados são definidos como os índices para cada critério (MARINS; SOUZA e BARROS, 2009).

Esses índices são utilizados na classificação do item analisado, que consiste em classificá-lo em cada critério, capturando o peso relativo de cada um, gerando uma nota final que define a classificação desse item (WANG et al., 2014).

Desse modo, o AHP relaciona cada critério entre si, gerando valores quantitativos de comparação entre eles. É dessa maneira que esse método transforma critérios qualitativos em quantitativos (WANG et al., 2014).

\section{METODOLOGIA}

\section{Design Science Research (DSR)}

O presente estudo adotou a DSR como metodologia de pesquisa pois, segundo Antunes et al. (2015), foca na resolução de um problema a fim de obter uma solução suficiente, desenvolvendo artefatos que sirvam em outras aplicações desse mesmo problema.

Ao se elaborar um diagrama que permita a empresa classificar um item em estoque, tem-se um artefato que pode ser utilizado em cada uma das áreas de negócio da empresa. Com isso, desenvolve-se uma solução que atende à necessidade imediata da companhia e que permita sua implementação em outras áreas (ANTUNES; DRESCH e LACERDA, 2015). 
O desenvolvimento desses artefatos é justamente o que difere a DSR das demais metodologias, como a Pesquisa-Ação e o Estudo de Caso (DRESCH, 2013). Esses artefatos permitem a ampliação do conhecimento e a possibilidade de aplicação das soluções em outras situações (ANTUNES; DRESCH e LACERDA, 2015), o que vai de encontro com a necessidade da empresa estudada. Isso é possível em função da generalização da solução para uma Classe de Problema, que consiste em um conjunto de problemas que possuem relação entre si e onde se podem obter artefatos que auxiliem na sua solução (DRESCH, 2013).

\section{Elaboração do Diagrama}

O Diagrama elaborado consiste em uma árvore de decisão, onde cada nó se refere a uma das dimensões analisadas: i) Volume consumido, ii) Valor em estoque (R\$) e iii) Criticidade do material para o processo.

Para o Volume consumido, obteve-se o histórico de dados da empresa, a fim de enquadrar os SKU segundo a classificação proposta. Para o Valor (R\$), obteve-se o valor dos materiais em estoque de acordo com o último inventário realizado, de forma a enquadrá-los, também, na classificação ABC. Por fim, para a Criticidade optou-se por adotar o AHP como método que permitisse enquadrar os SKU nos critérios definidos por especialistas.

Assim, elabora-se o Diagrama com base em três nós: i) Classificação $A B C$ quanto ao volume, ii) Classificação $A B C$ quanto ao valor $(R \$)$ e iii) Classificação quanta à Criticidade. Os dois primeiros nós são respondidos a partir de três caminhos: i) Classe A, ii) Classe B e iii) Classe C. Para o nó de Criticidade, as classificações são definidas a partir dos três caminhos definidos: i) Muito Crítico, ii) Crítico e iii) Pouco Crítico. Assim, ao se percorrer todo o Diagrama, obtêm-se a classificação final do SKU com base em três possibilidades: i) Estratégico, ii) Operacional e iii) Comum.

\section{Analytic Hierarchy Process (AHP)}

A aplicação da AHP consiste em definir n critérios de comparação e, a partir disso, compará-los par a para com base na Escala de Saaty (Tabela 1).

Tabela 1 - Escala de Saaty

\begin{tabular}{|c|l|}
\hline Escala & \multicolumn{1}{|c|}{ Descrição } \\
\hline 1 & Elementos de igual importância \\
\hline 3 & Moderada importância de um em relação ao outro \\
\hline 5 & Forte importância de um em relação ao outro \\
\hline 7 & Importância muito forte de um em relação ao outro \\
\hline 9 & Extrema importância de um em relação ao outro \\
\hline
\end{tabular}

Fonte: Marins, Souza e Barros (2009)

A comparação entre os $n$ critérios gera uma tabela com os pesos definidos a partir dessa comparação, calculando-se os autovetores.

Depois, com base na Escala de Saaty, realiza-se a comparação de cada critério (individualmente) com base em m subcritérios definidos. Assim, gera-se, para cada critério, uma matriz de pesos relativos, onde calculam-se os autovetores com base nas equações 
apresentadas.

A partir dos autovetores calculados, elabora-se um diagrama que representa a hierarquia entre os critérios e os subcritérios. Nesse diagrama, os critérios compõem os nós de nível 1, que se desdobram nos subcritérios no nível 2. Nos nós de critérios encontram-se os seus respectivos autovetores e, por sua vez, nos nós dos subcritérios, encontram-se os autovetores dos mesmos.

A partir desse Diagrama, são calculados os ranges de classificação, onde o range Máximo equivale ao Critério 1 e o Mínimo ao Critério 2. Para cada análise, realiza-se o enquadramento no subcritério correspondente ao critério analisado, capturando-se os autovetores associados. Com isso, soma-se cada uma dessas capturas a fim de se definir a classificação dentro dos ranges definidos.

\section{RESULTADOS}

\section{Elaboração do Diagrama}

O diagrama elaborado define a Classificação $A B C$ quanto ao valor $(R \$)$ e quanto ao volume em dois nós, onde os caminhos representam a classificação definida para o SKU analisado. Para o último nó (Criticidade), adotou-se três caminhos possíveis de classificação (Muito Crítico, Crítico e Pouco Crítico) que são definidos a partir da análise AHP para cada SKU. Dessa forma, percorrem-se todos os caminhos com base na classificação em cada dimensão adotada, obtendo-se a classificação final.

Essa classificação final é definida com base nos parâmetros estabelecidos pelos especialistas da empresa. A Tabela 2 resume esses parâmetros.

Tabela 2 - Classificação final

\begin{tabular}{|l|l|}
\hline \multicolumn{1}{|c|}{ Classificação final } & \multicolumn{1}{c|}{ Descrição } \\
\hline Estratégico & $\begin{array}{l}\text { SKU que interrompam o processo produtivo } \\
\text { ou que gerem danos em SMS }\end{array}$ \\
\hline Operacional & $\begin{array}{l}\text { SKU que atrasem o processo produtivo ou } \\
\text { que possam gerar danos em SMS }\end{array}$ \\
\hline Comum & $\begin{array}{l}\text { SKU que não atrasem o processo produtivo } \\
\text { ou não gerem danos de SMS }\end{array}$ \\
\hline
\end{tabular}

A classificação como Estratégico se dá sempre que o SKU seja classificado como Muito Crítico em relação à Criticidade, uma vez que esses materiais podem causar danos de SMS ou prejuízos financeiros por conta de atrasos e paradas do processo.

Quando o SKU apresenta classificação A tanto para Volume quanto para Valor (R\$), sempre será enquadrado como Estratégico, pois possuem elevado consumo e valor em estoque, impactando as operações da empresa e a realização contábil da mesma.

Para os SKU que são classificados como Crítico na Criticidade, sempre se adota a classificação final de Operacional, em função do potencial de causar impactos financeiros e de SMS. A mesma classificação final é dada para aqueles SKU cuja classificação em Volume ou Valor apresentem a combinação de classificação A e B ou B e A, visto que apre- 
sentam moderado consumo e valor $(R \$)$. O Diagrama completo (Anexo $A$ ) apresenta todas as possibilidades de classificação ao final dos caminhos percorridos após cada nó.

\section{Curva ABC}

A curva $\mathrm{ABC}$ para as unidades consumidas considerou o histórico de 5 anos, a fim de obter dados mais consistentes quanto a captura de padrões ao longo do tempo. No entanto, dado o escopo definido para este trabalho, elaborou-se a Curva $A B C$ analisando todos os SKU da área de Refino e Energia. A partir disso, identificou-se, para cada SKU analisado, o enquadramento nas classes A, B ou C. A Tabela 3 apresenta as faixas de valor da curva ABC apresentada.

Tabela 3 - Curva ABC

\begin{tabular}{|c|c|c|}
\hline Classe do item & Faixa em valor (R\$) & $\begin{array}{c}\text { Faixa em unidades } \\
\text { consumidas (5 anos) }\end{array}$ \\
\hline A & 1 milhão -4 milhões & 100 mil -500 mil \\
\hline B & 201 mil -999 mil & 30 mil -99 mil \\
\hline C & $100-200$ mil & $1-29$ mil \\
\hline
\end{tabular}

A partir desses dados, classificou-se os SKU quanto ao consumo e ao valor em estoque $(R \$)$ conforme apresentado na Tabela 4 - Classificação na Curva ABC.

Tabela 4 - Classificação na Curva ABC

\begin{tabular}{|l|c|c|}
\hline \multicolumn{1}{|c|}{ SKU } & Valor em $\mathbf{R} \$$ - Faixa ABC & $\begin{array}{c}\text { Valor consumido em } \\
\text { unidades (5 anos) - } \\
\text { Faixa ABC }\end{array}$ \\
\hline Reagentes químicos & $\mathrm{B}$ & $\mathrm{A}$ \\
\hline Válvulas esfera & $\mathrm{A}$ & $\mathrm{C}$ \\
\hline Tubos de Condução A/C & $\mathrm{B}$ & $\mathrm{A}$ \\
\hline EPI & $\mathrm{C}$ & $\mathrm{B}$ \\
\hline $\begin{array}{l}\text { Equipamentos de suporte } \\
\text { à rede TIC }\end{array}$ & $\mathrm{C}$ & $\mathrm{C}$ \\
\hline
\end{tabular}

\section{AHP}

Para a definição dos critérios de criticidade dos SKU, consultou-se os especialistas da empresa, que identificaram os seguintes: i) Disponibilidade do SKU no mercado, ii) Criticidade para a produção e iii) Impacto em SMS. A partir desses critérios, classifica-se o SKU em relação a Criticidade considerando-o Muito Crítico, Crítico ou Pouco Crítico. A TABELA 5 apresenta o detalhamento desses critérios. 
Tabela 5 - Critérios de Criticidade

\begin{tabular}{|c|c|c|c|}
\hline \multicolumn{4}{|c|}{ Criticidade para a Curva ABC } \\
\hline Critério & Muito crítico & Crítico & Pouco crítico \\
\hline $\begin{array}{l}\text { Disponibilidade do } \\
\text { SKU no mercado }\end{array}$ & $\begin{array}{l}\text { Importado ou } \\
\text { Nacional com } \\
\text { fornecedor } \\
\text { exclusivo }\end{array}$ & $\begin{array}{l}\text { Nacional com } \\
\text { menos de } 3 \\
\text { fornecedores ou } \\
\text { Importado }\end{array}$ & $\begin{array}{l}\text { Nacional com mais } \\
\text { de } 3 \text { fornecedores }\end{array}$ \\
\hline $\begin{array}{c}\text { Criticidade para a } \\
\text { produção }\end{array}$ & Interrompem & Atrasam & Sem rupturas \\
\hline Impactos de SMS & Danos graves & Danos moderados & Sem danos \\
\hline
\end{tabular}

\section{Definição dos pesos}

Conforme Seção 2, os critérios foram comparados entre si utilizando a Escala de Saaty. Para definição dos pesos segundo essa escala, foram convocados especialistas que discutiram essa classificação a fim de chegar ao consenso apresentado na Tabela 6.

Tabela 6 - Matriz de relacionamentos

\begin{tabular}{|c|c|c|c|}
\hline & $\begin{array}{c}\text { Disponibilidade } \\
\text { do SKU no } \\
\text { mercado }\end{array}$ & $\begin{array}{c}\text { Criticidade para a } \\
\text { produção }\end{array}$ & Impacto em SMS \\
\hline $\begin{array}{c}\text { Disponibilidade o } \\
\text { SKU no mercado }\end{array}$ & 1 & $1 / 5$ & $1 / 7$ \\
\hline $\begin{array}{c}\text { Criticidade para a } \\
\text { produção }\end{array}$ & 6 & 1 & $1 / 3$ \\
\hline Impacto em SMS & 7 & 3 & 1 \\
\hline
\end{tabular}

Os especialistas entendem que o Impacto em SMS é o fator mais crítico para um SKU, em função dos riscos que a falha nesse critério pode acarretar tanto para a segurança e meio-ambiente, quanto para a imagem da empresa, sendo mais crítico a ocorrência de um impacto em SMS do que a interrupção do processo produtivo. Assim, esse critério apresenta os maiores índices quando comparados aos outros dois.

A Criticidade para a produção foi apontada como o segundo critério mais crítico e, portanto, com peso maior quando comparado à Disponibilidade de SKU no mercado. Por fim, este critério foi definido como o de menor criticidade quando comparado aos demais, visto que medidas mitigatórios para ele são mais fáceis de serem estabelecidas.

A partir da matriz da Tabela 6 - Matriz, calcularam-se os autovetores normalizados para cada um dos critérios, obtendo-se os seguintes resultados: i) Disponibilidade do SKU no mercado: 0,071, ii) Criticidade para a produção: 0,291 e iii) Impactos em SMS: 0,638.

\section{Definição dos pesos relativos}

Após a realização da comparação entre os critérios, elabora-se a matriz de pesos relativos para cada um dos critérios considerando-se a classificação em Muito Crítico, Crítico e Pouco Crítico. As Tabelas 7, 8 e 9 apresentam esse relacionamento para o critério de Disponibilidade do SKU no mercado. 
Tabela 7 - Matriz de pesos

\begin{tabular}{|c|c|c|c|c|}
\hline \multicolumn{5}{|c|}{ Disponibilidade do SKU no mercado } \\
\hline & Muito crítico & Crítico & Pouco crítico & Normalização \\
\hline Muito crítico & 1 & 5 & 7 & 0,731 \\
\hline Crítico & $1 / 5$ & 1 & 3 & 0,188 \\
\hline Pouco crítico & $1 / 7$ & $1 / 3$ & 1 & 0,081 \\
\hline
\end{tabular}

Tabela 8 - Matriz de pesos

\begin{tabular}{|c|c|c|c|c|}
\hline \multicolumn{5}{|c|}{ Criticidade para a produção } \\
\hline & Muito crítico & Crítico & Pouco crítico & Normalização \\
\hline Muito crítico & 1 & 5 & 9 & 0,722 \\
\hline Crítico & $1 / 5$ & 1 & 7 & 0,227 \\
\hline Pouco crítico & $1 / 9$ & $1 / 7$ & 1 & 0,051 \\
\hline
\end{tabular}

Tabela 9 - Matriz de pesos

\begin{tabular}{|c|c|c|c|c|}
\hline \multicolumn{5}{|c|}{ Impactos em SMS } \\
\hline & Muito crítico & Crítico & Pouco crítico & Normalização \\
\hline Muito crítico & 1 & 9 & 9 & 0,787 \\
\hline Crítico & $1 / 9$ & 1 & 7 & 0,167 \\
\hline Pouco crítico & $1 / 9$ & $1 / 7$ & 1 & 0,046 \\
\hline
\end{tabular}

\section{Elaboração do diagrama hierárquico da AHP}

A partir dos autovetores calculados, calculam-se as faixas de classificação em Muito Crítico, Crítico e Pouco Crítico, conforme Tabela 10 - Range de criticidade.

Tabela 10 - Range de criticidade

\begin{tabular}{|c|c|c|}
\hline Muito Crítico & Crítico & Pouco Crítico \\
\hline $0,578-0,764$ & $0,236-0,577$ & $0,050-0,236$ \\
\hline
\end{tabular}

\section{Aplicação do diagrama para os SKU}

A partir do diagrama (Figura 1) e da Tabela de Ranges (Tabela 10), os SKU analisados foram classificados quanto a Criticidade Tabela 11 - Criticidade SKU 
Tabela 11 - Criticidade SKU

\begin{tabular}{|c|c|c|c|c|c|}
\hline SKU & $\begin{array}{l}\text { Disponibilida } \\
\text { de do SKU no } \\
\text { mercado }\end{array}$ & $\begin{array}{c}\text { Criticidade } \\
\text { para a } \\
\text { produção }\end{array}$ & $\begin{array}{l}\text { Impacto } \\
\text { em SMS }\end{array}$ & $\begin{array}{l}\text { Cálculo para } \\
\text { classificação }\end{array}$ & $\begin{array}{c}\text { Classificaçã } \\
\text { o conforme } \\
\text { range da } \\
\text { AHP }\end{array}$ \\
\hline $\begin{array}{l}\text { Reagentes } \\
\text { químicos }\end{array}$ & Crítico & $\begin{array}{l}\text { Muito } \\
\text { crítico }\end{array}$ & $\begin{array}{l}\text { Muito } \\
\text { crítico }\end{array}$ & $\begin{array}{c}\left(0,071^{\star} 0,188\right)+ \\
\left(0,281^{\star} 0,722\right)+ \\
\left(0,638^{*} 0,787\right) \\
=\mathbf{0 , 7 1 8}\end{array}$ & Muito crítico \\
\hline $\begin{array}{l}\text { Válvulas } \\
\text { esfera }\end{array}$ & Crítico & Crítico & $\begin{array}{l}\text { Muito } \\
\text { crítico }\end{array}$ & $\begin{array}{c}\left(0,071^{\star} 0,188\right)+ \\
\left(0,281^{\star} 0,227\right)+ \\
\left(0,638^{*} 0,787\right) \\
=\mathbf{0 , 5 7 9}\end{array}$ & Muito crítico \\
\hline $\begin{array}{c}\text { Tubos de } \\
\text { Condução A/C }\end{array}$ & Muito Crítico & $\begin{array}{l}\text { Muito } \\
\text { crítico }\end{array}$ & Crítico & $\begin{array}{c}\left(0,071^{\star} 0,731\right)+ \\
\left(0,281^{\star} 0,722\right)+ \\
\left(0,638^{*} 0,167\right) \\
=\mathbf{0 , 3 6 1}\end{array}$ & Crítico \\
\hline EPI & Pouco crítico & $\begin{array}{l}\text { Pouco } \\
\text { crítico }\end{array}$ & $\begin{array}{l}\text { Muito } \\
\text { crítico }\end{array}$ & $\begin{array}{c}\left(0,071^{\star} 0,081\right)+ \\
\left(0,281^{\star} 0,051\right)+ \\
\left(0,638^{*} 0,787\right) \\
=\mathbf{0 , 5 2 2}\end{array}$ & Crítico \\
\hline $\begin{array}{l}\text { Equipamentos } \\
\text { de suporte à } \\
\text { rede TIC }\end{array}$ & Crítico & $\begin{array}{l}\text { Pouco } \\
\text { crítico }\end{array}$ & $\begin{array}{l}\text { Pouco } \\
\text { crítico }\end{array}$ & $\begin{array}{c}\left(0,071^{\star} 0,188\right)+ \\
\left(0,281^{\star} 0,051\right)+ \\
\left(0,638^{*} 0,046\right) \\
=\mathbf{0 , 0 5 7}\end{array}$ & Pouco crítico \\
\hline
\end{tabular}

A aplicação do diagrama (Anexo A) para os SKU aos se percorrer todos os caminhos, resultou nas classificações finais apresentadas na Figura 1.

Figura 1 - Resultado do diagrama

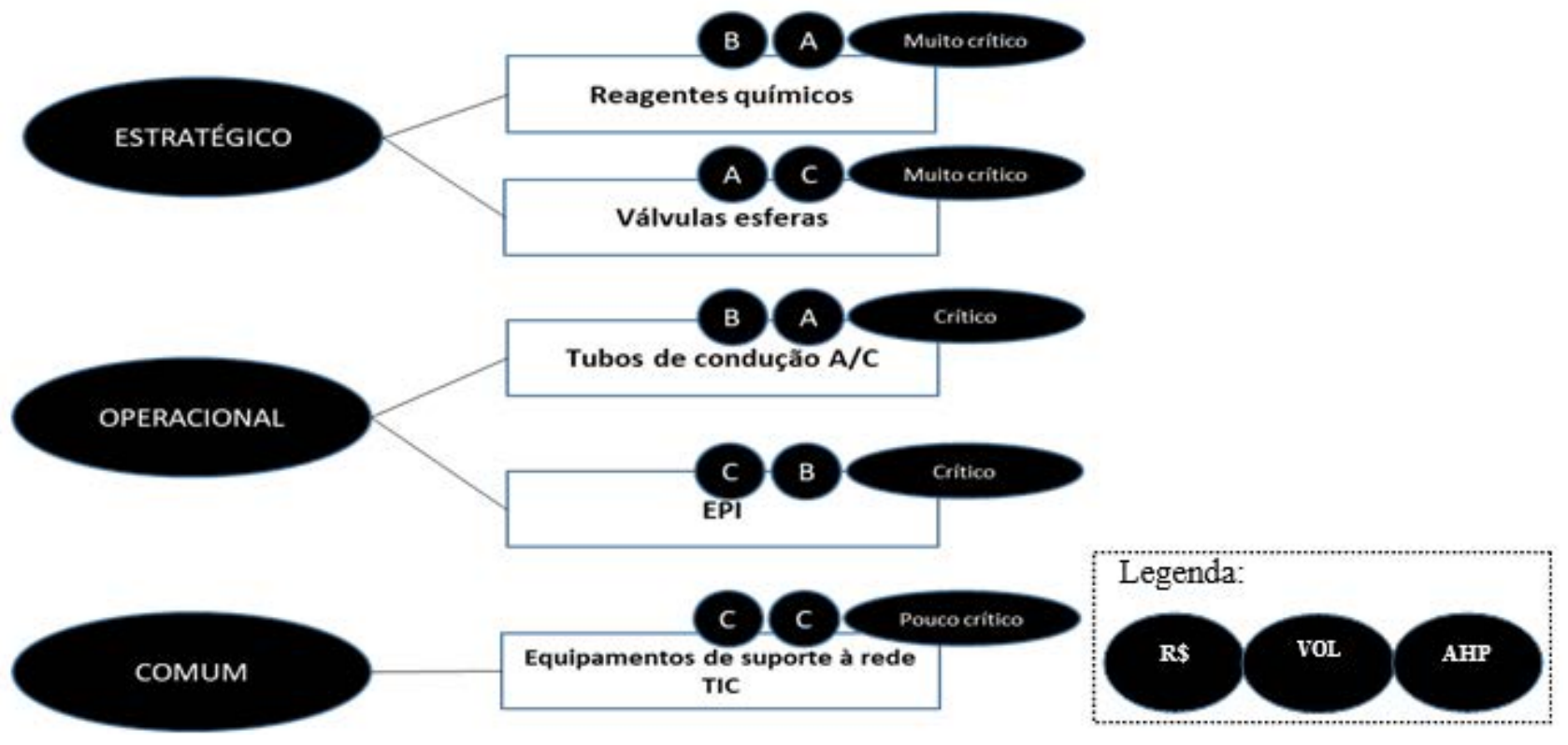

Ao se analisar as medidas de estoque, percebe-se que hoje há discrepância de resultados entre os SKU. Os reagentes químicos, por exemplo, apresentam faltas em torno de $15 \%$ (total de itens), bem como um excedente de $5 \%(\mathrm{R} \$)$. Entretanto, foi enquadrado como Estratégico, a exemplo dos SKU de Válvulas Esferas e EPI. Esses SKU, por sua vez, apresentam faltas de $55 \%$ e $2 \%$, e excedente de $1 \%$ e $42 \%$, respectivamente. Ao se simular 
a adoção de controles de estoque para esses SKU de maneira conjunta (como Estratégico), esperam-se faltas na ordem de $7 \%$ e excedente de $11 \%$, melhorando os resultados e, assim, otimizando a gestão de estoques da empresa.

\section{CONCLUSÕES}

O estudo propôs a criação de um Diagrama que permitisse a empresa adotar um modelo de Classificação de seus itens em estoque considerando Valor (R\$), Volume e Criticidade. Os resultados da implementação na área de Refino e Energia demostram o potencial que esse diagrama apresenta para auxiliar na tomada de decisão em gestão de estoque da empresa, uma vez que permite agrupar os itens com base nos critérios citados.

Pela adoção da DSR como metodologia de trabalho, entende-se que o Diagrama proposto seja um artefato que possa ser utilizado pela empresa para a classificação dos itens em outras áreas de negócio, obtendo resultados similares. Com isso, espera-se que o mesmo seja adotado nas demais áreas, a fim de definir um padrão de classificação que possa procedimentar essa análise na empresa.

Por fim, sugere-se a implementação desse modelo em outras empresas, a fim de validá-lo como um artefato útil na Classe de Problema a que pertence (Planejamento e Controle da Produção). Para tanto, pode ser necessária a inclusão de novos parâmetros, principalmente na aplicação do AHP, uma vez que o ramo da empresa (petróleo e gás) possui particularidades muito distintas de outros setores. Assim, futuros trabalhos podem contribuir com a melhoria do artefato, auxiliando a ampliar o conhecimento, uma das premissas da DSR.

\section{REFERENCIAL}

ANTUNES, J., DRESCH, A., e LACERDA, D. (2015). Design Science Research: A method for science and technology advancement. US: Springer. p.176.

DRESCH, A. (2013). Design Science e Design Science Research como Artefatos Metodológicos para Engenharia de Produção. Dissertação (Dissertação em Engenharia da Produção) UNISINOS. São Leopoldo, p. 184.

FLORES, B., e WHYBARK, D. (1988). Know your ABC. Management Decision. v26, 19-31.

HAUTANIEMI, P., e PIRTTILA, T. (1999). The choice of replenishment policies in an MRP environment. International Journal of Production Economics. v. 59, 85-92.

HOPP, H., e SPEARMAN, M. (2008). Factory Physics. USA: Waveland Press, Inc. 752 p.

MARINS, C.; SOUZA, D, e BARROS, M. (2009). O uso do método de análise hierárquica (AHP) na tomada. Pesquisa Operacional na Gestão do Conhecimento. v.11, 90-101.

MEHDIZADEH, M (2019). Integrating ABC analysis and rough set theory to control the inventories of distributor in the supply chain of auto spare parts. Computers and Industrial Engineering. v.139, 73-90.

MOLENEARS, A., BAETS, H., PINTELON, L., WAEYENBERGH, G. (2011). Criticality classification of spare parts: A case study. International Journal of Production Economics. v. 140, 570-578. 


$$
1
$$




\section{"Trocar é hom" : o pringípio econômieo descrito sob a noção de fronteira de possihilitiades de produçãa}

\section{"Exchanging is good": an economic pringiple deserilibed under the notion of production-possibility frontier}

Andre Menenguci Pires Universidade Federal de Santa Catarina - UFSC

Alexandre Manoel dos Santos Universidade Federal da Fronteira Sul - UFFS

Mabel Camara de Araujo Universidade Federal da Fronteira Sul - UFFS

Manoela Theodorovitz dos Santos Engenheira Civil, Hab. em Engenharia de Produção Civil - UFSC

Sergio Fernando Mayerle Universidade Federal de Santa Catarina - UFSC

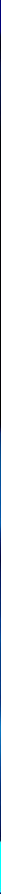


Este artigo apresenta o quinto princípio econômico denominado "o comércio é bom para todos" na forma do eufemismo "trocar é bom!". Ele é importante no entendimento do comportamento dos agentes que atuam num sistema econômico sob um processo de equilíbrio espacial de preços. Ele também é base para o entendimento das capacidades produtivas dos produtores que visam atender uma demanda de mercado, definida por consumidores, num contexto de concorrência perfeita. Para descrever sua validade utilizou-se duas formulações. A primeira representa uma abordagem de pesquisa operacional sobre o conceito de economia denominado "fronteira de possibilidades de produção", visando oferecer uma medida de eficiência como critério técnico de comparação. Esta fronteira descreve o conjunto de alternativas de produção possíveis. $\mathrm{O}$ contraste final de eficiências medidas entre planos de produção distintos é a própria validação. A segunda utiliza os conceitos de álgebra vetorial para estabelecer o conjunto de pontos de um espaço métrico que atende a condição de pertinência ao plano de produção, numa analogia ao conceito de fronteira de possibilidades. Os resultados obtidos evidenciam que as duas abordagens oferecem as mesmas medidas de contrastes utilizadas para comprovar efetivamente a validade do princípio estudado.

Palavras-chave: princípios econômicos. eficiência. sistema de produção. vantagem comparativa. agentes econômicos. equilíbrio espacial de preços. fronteira de possibilidades de produção.

\section{Alistrat}

This article presents the fifth economic principle named "trade is good for everyone" in the form of euphemism "exchanging is good!". It is relevant to understand the behavior of agents that act on certain economic system that is under a spatial price equilibrium process. It is also a basis for understanding the producers's capacities aiming to meet a market demand, defined by consumers, in a perfect competition context. To describe the validity of the referred principle, two classic formulations were used. the former represents an operational research approach on the concept of economy named "production-possibility frontier- (PPF)", in order to offer an efficiency measure as a technical comparison criterion. This frontier describes the set of possible production alternatives. The final contrast of efficiencies measured between different production plans is the proof of the principle's validity. The second formulation uses the vector algebra concepts to establish the set of points of a metric space that meets the condition of belonging to the production plan-in an analogy to the ppf concept. The results obtained evidence that the two approaches offer the same contrast measures used to provide effectively the validity's proof for the referred principle.

Keywords: economic principle. economical efficiency. production systems. comparative advantage. economical agents. spatial price equilibrium. production-possibility frontier. 


\section{INTRODUÇÃO}

Este artigo faz referência a um dos dez princípios clássicos de Economia denominado "O Comércio Pode ser Bom para Todos". Por meio deste princípio, pode-se inferir cientificamente sobre o comportamento e a maneira de como as pessoas interagem uma com as outras em um dado sistema econômico. Segundo Mankiew (2006), Economia pode ser definida como a área do conhecimento que estuda as maneiras pelas quais uma sociedade administra os seus recursos escassos. Esta ciência estabelece que o comércio permite que as pessoas se especializem em atividades onde são mais produtivas e eficientes e, como consequência, desfrutem de uma maior variedade de bens e serviços a um custo menor.

Para demonstrar a validade deste princípio econômico, é apresentado a seguir um exemplo de um pequeno sistema de produção formado por três produtores que produzem quantidades diferentes de três tipos de produtos. Um sistema econômico simples assim pode ser descrito por meio de um plano de produção conforme representado na Figura 1. Por uma questão de equidade e limitação de recursos, os produtores $\left\{\mathrm{P}_{1} ; \mathrm{P}_{2} ; \mathrm{P}_{3}\right\}$ dispõem igualmente de 24 [horas/dia] para realizar seu plano diário de produção dos produtos \{PA; $\mathrm{PB}_{\mathrm{B}}$ PC\}. Neste timing já estão incluídos os tempos necessários para descansar, para cuidadar da família, para cuidar das relações sociais e de demais atividades, para além do tão prazeroso lazer. Obviamente, cada ser humano decide, por sua conta e risco, como vai aproveitar melhor o seu tempo disponível em cada dia de vida. Considera-se que a matriz de aproveitamento do tempo de cada produtor Pi está representada pelo plano de produção Пı para os três tipos de produtos. As demais atividades estão diluídas dentro do referido timing necessário para produzi-los.

Neste exemplo, a quantidade máxima de produtos que podem ser produzidos por um produtor em um único dia está descrita na Figura 1 pelos pontos $A, B$ e C. Eles são os extremos na cor vermelha de cada um dos eixos cartesianos $\{i ; j ; k\}$ respectivamente, sendo quantidades mutuamente exclusivas; isto é, se um produtor se dedicar exclusivamente para produzir somente o produto $\mathrm{PA}$, então, sua produção máxima no dia será igual à quantidade A. Essa condição é análoga para os produtos $\mathrm{PB}, \operatorname{com} \mathrm{B}, \mathrm{e} \mathrm{PC} \operatorname{com} \mathrm{C}$.

Note-se que qualquer combinação envolvendo quantidades diferentes dos valores máximos de cada produto que um produtor pode produzir também deverá consumir plenamente as 24 [horas/dia] disponíveis num dia produtivo deste produtor. Este aspecto caracteriza um plano de produção possível para qualquer produtor. Exige-se que a produção total dos produtos atendam as necessidades individuais dos produtores.

Na Figura 1 tem-se o ponto $S=(J, N, K)$ como uma representação adequada para uma combinação de produção possível, que efetivamente pertence ao plano de produção Пı em questão, onde as necessidades individuais de um produtor Pi devem ser atendidas. Assim, J representa a quantidade do produto $\mathrm{PA}, \mathrm{K}$ a quantidade de $\mathrm{Pc}$ e, por último, $\mathrm{N}$ representa a quantidade possível de ser produzida do produto $\mathrm{PB}_{\mathrm{B}}$ no ponto $\mathrm{S} \in \Pi$. 
Figura 1 - O Plano de produção Пı para o Produtor $\mathrm{Pi}$, com i =1,2,3.

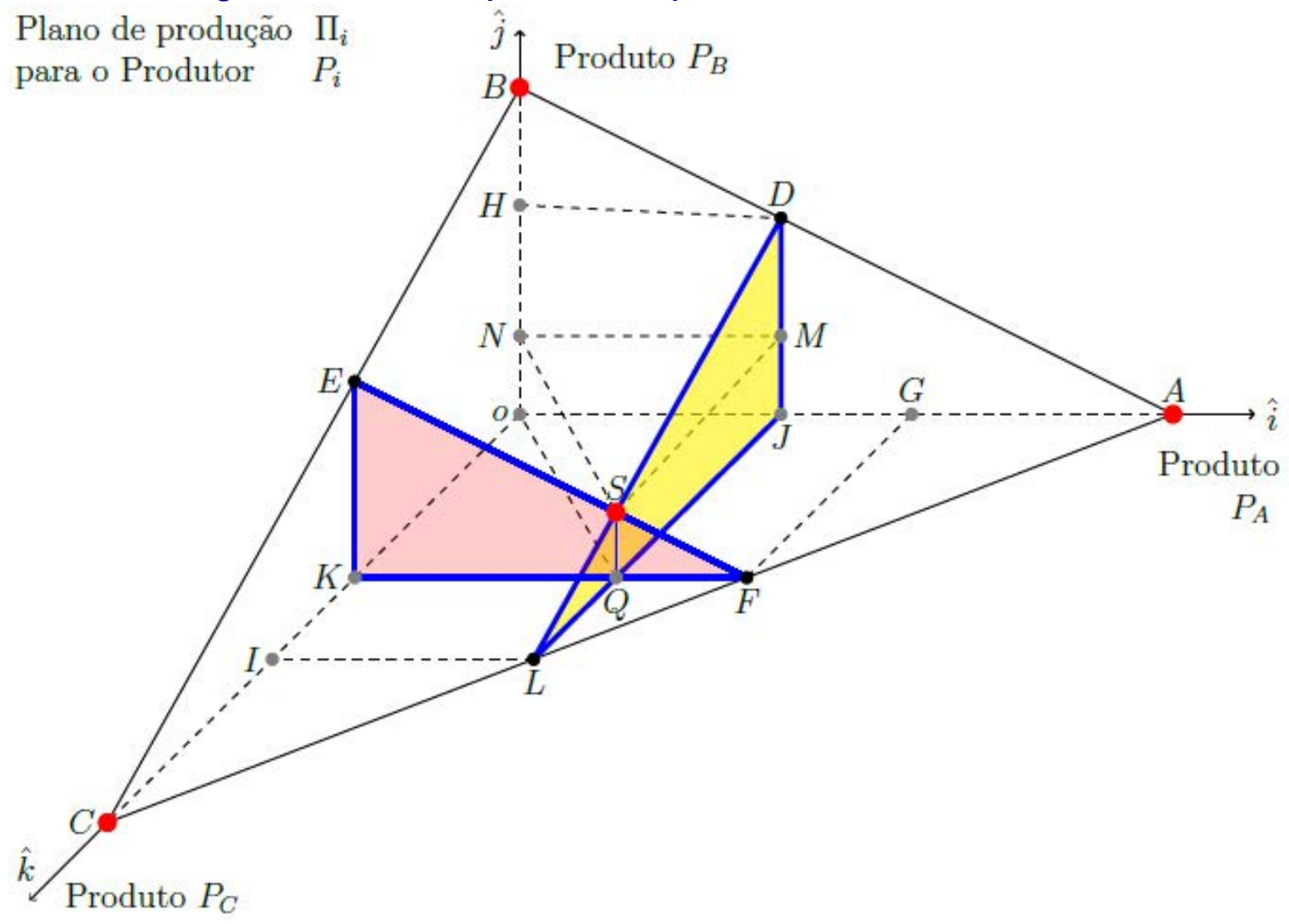

O plano de produção $\Pi \mathrm{i}$ acima descreve apenas dois graus de liberdade para se determinar completamente o vetor ${ }^{1}$ posição $S$, descrito por $S=(J . I+N . j+K . K)$, formado por três dimensões básicas. Escolhem-se as quantidades a serem produzidas de dois produtos e, posteriormente, calcula-se a quantidade possível de se produzir o terceiro produto com o tempo que resta após a produção dos dois primeiros. Considerando-se que as quantidades de produtos a serem produzidos devem consumir todo o tempo diário de produção de um produtor, um programa de produção possível $S=(J, N, K)$ é representado em (1.1). Assim, para a determinação do programa solução $S=(J, N, K) \in \Pi ı$, o ponto solução ilustrado na Figura 1, tendo-se assumido que um produtor $\mathrm{PI}$ decide produzir $\mathrm{J}$ quantidades do produto $\mathrm{PA}$ e ainda produzir $\mathrm{K}$ quantidades do produto $\mathrm{Pc}$, tem-se que a quantidade $\mathrm{N}$ de produtos PB possível de ser produzida é calculada pela expressão (1.2).

Dado um ponto $S=(J, N, K) \in \Pi_{i}$, tem-se:

onde, considerando o ortante positivo:

$$
\begin{array}{r}
\quad\left(\frac{24}{A} \cdot J+\frac{24}{B} \cdot N+\frac{24}{C} \cdot K\right)=24 \\
N=B \cdot\left[1-\left(J \cdot \frac{1}{A}+K \cdot \frac{1}{C}\right)\right]
\end{array}
$$

$$
\begin{gathered}
0 \leq J \leq A \\
0 \leq N \leq B \\
0 \leq K \leq C
\end{gathered}
$$

10 vetor S é também denominado vetor solução ou programa de produção para o problema de determinação do plano de produção Пı para o produtor $P$ I. 
As expressões (1.1) à (1.5) possuem as seguintes interpretações:

1. Os programas de produção $S=(J . i+N . j+K . k) €$ Пi se definem no ortante positivo: as quantidades de produtos $\{\mathrm{J} ; \mathrm{N} ; \mathrm{K}\}$ nos eixos $\{\mathrm{i} ; \mathrm{j} ; \mathrm{k}\}$ são iguais ou maiores que zero. Não faz sentido produzir quantidades negativas de produtos em um plano de produção Пi;

2. As inversas $\left\{(24 / A)^{-1} ;(24 / B)^{-1} ;(24 / C)^{-1}\right\}$ das razões em (1.1) representam as produtividades máximas do produtor $\mathrm{PI}$ em produzir, respectivamente, os produtos $\left\{\mathrm{PA}_{\mathrm{A}}\right.$; $\mathrm{PB}_{\mathrm{B}}$ PC\} em um dia pleno de trabalho. São também vistas como medidas de fluxo ou de velocidade de produção. O termo 24/A é uma medida de tempo (horas) necessário para o produtor PI produzir um único produto $\mathrm{PA}$;

3. Os termos entre parenteses (J.(1/A) + K.(1/C)) contidos em (1.2) representam a soma de percentis do tempo de produção diário que é necessário para produzir as quantidades $(\mathrm{J}+\mathrm{K})$ de produtos PA e Pc. O resultado entre colchetes [1 - ( J.(1/A) + $\mathrm{K} .(1 / \mathrm{C}))$ ] representa o saldo (complemento de 1) de percentil de tempo que resta para ser utilizado na produção do produto PB. Multiplicando-se este valor por B, tem-se a determinação da quantidade $\mathrm{N}$ possível de ser produzida do produto $\mathrm{B}$ no tempo complementar;

4. Os pontos $\{L=(J, 0, I) ; F=(G, 0, K)\}$, contidos na linha $C A$ da Figura 1, representam quantidades de produtos PA e Pc que consomem completamente as 24 [horas/ dia] para realizar o plano diário de produção do produtor. Logo, $\mathrm{N}=0$, pois nestes pontos tem-se que J.(1/A) + K. $(1 / \mathrm{C})=100 \%$. Isto acontece com qualquer ponto localizado na linha CA do plano $\Pi$;

5. O ponto $E=(0,\|E K\|, K)$, contido na linha $C B$ da Figura 1, representa quantidades de produtos $\mathrm{PB}$ e PC que consomem completamente 24 [horas/dia] para realizar o plano diário de produção do produtor. Logo $\mathrm{J}=0$, pois neste ponto tem-se N.(1/B) + $\mathrm{K} .(1 / \mathrm{C})=100 \%$. Isto acontece com qualquer ponto localizado na linha $\mathrm{CB}$ do plano Пı;

6. Analogamente, o ponto $D=(\mathrm{J}, \mathrm{H}, 0)$, contido na linha BA da Figura 1, representa quantidades de produtos $\mathrm{PB}_{\mathrm{B}}$ e $\mathrm{PA}$ que consomem as 24 [horas/dia] para realizar o plano diário de produção. Logo $K=0$, pois neste ponto tem-se $N .(1 / B)+J .(1 / A)=$ $100 \%$. Isto acontece com qualquer ponto localizado na linha BA do plano Пı.

Considera-se muito importante que o leitor visualize os elementos presentes nas expressões (1.1) e (1.2) e perceba as suas implicações geométricas descritas na Figura 1. Trata-se de um exercício de abstração que é recorrente em Engenharia. Por exemplo, imagine que o ponto $S=(\mathrm{J}, \mathrm{N}, \mathrm{K})$ possa se deslocar livremente para qualquer posição sobre o plano Пı. Isso quer dizer que $S \in \Pi$. Agora, imagine ainda você movendo ele com sua mente para uma outra posição deste plano. Esta nova posição também representa um programa de produção possível para o produtor Pı. Neste sentido, define-se o plano Пı como "Fronteira de Possibilidades de Produção" do produtor PI , conforme as definições em Mankiw (2006).

Os planos de produção semelhantes ao plano Пı são considerados à luz de uma importante medida de performance utilizada para avaliar a eficiência de sistemas entre si: a tão referenciada "produtividade". Neste sentido, para se melhorar os resultados de um sistema, considerando-se que os tempos em um dia de trabalho não podem ser aumentados para além do limite superior de 24 [horas/dia] de produção, então, somente resta ao produ- 
tor aumentar a eficiência de seu sistema de produção pelo aumento da sua produtividade, isto é; pelo aumento de sua capacidade de produzir uma quantidade maior de produtos num mesmo período de tempo. Isto quer dizer que o aumento da eficiência de um produtor depende do aumento de sua expertise sobre o seu próprio sistema de produção e sobre as relações que ele mantém em Sociedade. Assim, para aumentar a eficiência de um sistema, faz-se necessário aumentar a sua produtividade. Se todos os produtores fizerem assim, então, a eficiência global dos sistemas envolvidos se eleva significativamente. $O$ aumento da eficiência global dos sistemas produtivos em Sociedade é um dos focos da abordagem em Engenharia. Efetivamente, o mundo melhora e a qualidade de vida se eleva quando humanos desenvolvem relações institucionais em sociedade que são mais eficientes. Esta é uma das bases do tripé da Sustentabilidade: Economia dos sistemas em sociedade, além de Meio Ambiente e Sociedade.

\section{UM EXEMPLO PRÁTICO DE “TROCAR É BOM!”}

O plano Пi de produção genérico que está descrito na Figura 1 pode ser utilizado para demonstrar a validade do quinto princípio econômico quando aplicado a um pequeno exemplo prático. Neste exemplo, o sistema econômico permanece formado por três produtores $\left\{P_{1} ; P_{2} ; P_{3}\right\}$ que são especializados na produção de três tipos de produtos $\left\{P_{A} ; P_{B}\right.$; $\mathrm{Pc}\}$.

Antes da comprovação do referido princípio, duas perguntas levantam uma mesma e importante questão: ela diz respeito à maneira pela qual cada produtor busca atender sua própria necessidade por produtos e organiza as suas respectivas produções. Respondendo-se uma delas, tem-se a demonstração desejada para o quinto princípio. São elas:

- Efetivamente, vale a pena para todos os produtores trocarem entre si o resultado de sua produção especializada, para ter suas necessidades básicas atendidas?

- Será que é melhor para todos os produtores que cada produtor produza isoladamente os produtos para atender as suas próprias necessidades, desconsiderando as especialidades dos demais produtores?

Uma metodologia de quatro passos é utilizada para responder as perguntas acima. O primeiro passo caracteriza o sistema econômico tomado como exemplo, por meio de dados que identifiquem os produtores e suas capacidades individuais máximas de produção. Trata-se da etapa associada ao enunciado do problema que se deseja resolver. A Tabela 1 descreve os produtores e suas capacidades de produção diária de produzir os produtos $\left\{\mathrm{PA}_{\mathrm{A}}\right.$ Р $\left.\mathrm{B} ; \mathrm{Pc}\right\}$. Note-se que o produtor $\mathrm{P}_{1}$ é mais produtivo na produção do produto $\mathrm{Pc}$ que os demais produtores: a produtividade dele é três vezes superior àquela de $P_{3}$ e duas vezes maior que a de $\mathrm{P}_{2}$. Analogamente, a produtividade de $\mathrm{P}_{2}$ na produção de $\mathrm{P}_{\mathrm{A}}$ é relativamente superior às produtividades de $P_{1}$ (o dobro) e de $P_{3}$, oito vezes maior. Já o produtor $P_{3}$ é o mais produtivo na produção de $\mathrm{PB}_{\mathrm{B}}$, sendo cinco vezes mais produtivo que $\mathrm{P}_{1}$ e mais que duas vezes que $P_{2}$. 
Tabela 1 - Produtividade máxima dos produtores na produção de três produtos

\begin{tabular}{cccc}
\hline & Produto $P_{A}$ & Produto $P_{B}$ & Produto $P_{C}$ \\
Produtores $P_{i}$ & $A_{i}$ & $B_{i}$ & $C_{i}$ \\
& {$\left[\frac{\text { unid }}{\text { dia }}\right]$} & {$\left[\frac{\text { unid }}{\text { dia }}\right]$} & {$\left[\frac{\text { unid }}{\text { dia }}\right]$} \\
\hline$P_{1}$ & $A_{1}=24$ & $B_{1}=12$ & $C_{1}=36$ \\
$P_{2}$ & $A_{2}=48$ & $B_{2}=24$ & $C_{2}=18$ \\
$P_{3}$ & $A_{3}=6$ & $B_{3}=60$ & $C_{3}=12$ \\
\hline
\end{tabular}

As produtividades descritas acima estão bem definidas: elas refletem as expertises $^{2}$ dos produtores e as disponibilidades de recursos que cada um possui neste exemplo. O segundo passo metodológico consiste na identificação completa do vetor de necessidades pessoais diárias de cada produtor pelos produtos eles que são capazes de produzir, individualmente, com sua expertise e com os seus recursos disponíveis.

Tabela 2 - Necessidades diárias dos Produtores pelos três produtos que produzem

\begin{tabular}{|c|c|c|c|}
\hline Produtores $P_{i}$ & $\begin{array}{c}\text { Produto } P_{A} \\
J_{i} \\
{\left[\frac{\text { unid }}{\text { dia }}\right]}\end{array}$ & $\begin{array}{c}\text { Produto } P_{B} \\
N_{i}=B_{i} \cdot\left[1-\left(J_{i} \cdot \frac{1}{A_{i}}+K_{i} \cdot \frac{1}{C_{i}}\right)\right] \\
{\left[\frac{\text { unid }}{\text { dia }}\right]}\end{array}$ & $\begin{array}{c}\text { Produto } P_{C} \\
K_{i} \\
{\left[\frac{\text { unid }}{\text { dia }}\right]}\end{array}$ \\
\hline$P_{1}$ & $J_{1}=8$ & $N_{1}=4$ & $K_{1}=12$ \\
\hline$P_{2}$ & $J_{2}=16$ & $N_{2}=8$ & $K_{2}=6$ \\
\hline$P_{3}$ & $J_{3}=2$ & $N_{3}=20$ & $K_{3}=4$ \\
\hline $\begin{array}{l}\text { Necessidades totais } \\
\text { no sistema econômico }\end{array}$ & $J_{T}=26$ & $N_{T}=32$ & $K_{T}=22$ \\
\hline
\end{tabular}

A Tabela 2 descreve os produtores e suas necessidades diárias por produtos. Note-se que a terceira coluna apresenta o valor das necessidades pelo produto $\mathrm{PB}$, calculadas de acordo com a expressão (1.2). Isto é, dadas duas necessidades $\{\mathrm{JI} ; \mathrm{Kl}\}$ atribuídas ao produtor $\mathrm{PI}$, a sua terceira necessidade Nı será uma decorrência do tempo restante para a produção de $\mathrm{PB}_{\mathrm{B}}$. É importante lembrar que neste exemplo considera-se a possibilidade dos produtores atuarem isoladamente, ignorando as capacidades dos demais produtores, para comprovar a validade do princípio econômico "Trocar é bom!". Os produtores tem que efetivamente lidar ${ }^{3}$ com as suas limitações. As necessidades de um produtor estão também acopladas às suas capacidades de produção, por conta de uma importante sinalização que todo sistema econômico oferece: a demanda de mercado, representada aqui neste exemplo pelos valores totais do conjunto de necessidades descritos na última linha desta tabela. Assim, espera-se que a produção total de produto PA pelos produtores seja maior ou igual à JT. Sendo maior, haverá excedente de produção deste item. Idem para as duplas PB com NT e Pc com KT.

O terceiro passo trata de consolidar as informações descritas nas Tabelas 1 e 2, realizando um processo de comparação simples entre os resultados obtidos por dois modos distintos de atuação dos produtores no sistema econômico exemplificado: o modo (i)

2 Esta etapa apresenta a condição que é comum à todos os produtores em sistemas econômicos quaisquer: tanto a especialidade deles, como os seus recursos disponíveis para a produção, são limitados.

3 Trata-se de uma das ontologias humanas: as necessidades humanas, historicamente, são infinitas e os recursos disponíveis (naturais, ambientais e econômicos), são escassos, sempre limitados. 
Modo I - Isolado, onde se desconsidera a capacidade dos demais produtores. Neste modo, os produtores não fazem mais nada além de produzir para atender as suas próprias necessidades ${ }^{4}$; e o modo (ii) Modo II - Não-Isolado, onde se integra sistemicamente as capacidades de produção dos produtores para atender as demandas do sistema econômico, que buscam produzir segundo o critério de máxima eficiência individual. Neste modo, os produtores se dedicam à produzir somente um tipo de produto considerando sua máxima produtividade.

Tabela 3 - Planos de produção possíveis: Modo I e Modo II em comparação

\begin{tabular}{crrrrrr}
\hline & \multicolumn{3}{c}{ Modo I } & \multicolumn{3}{c}{ Modo II } \\
Produtores $P_{i}$ & $P_{A}$ & $P_{B}$ & $P_{C}$ & $P_{A}$ & $P_{B}$ & $P_{C}$ \\
& 8 & 4 & 12 & 0 & 0 & 36 \\
& 16 & 8 & 6 & 48 & 0 & 0 \\
$P_{1}$ & 2 & 20 & 4 & 0 & 60 & 0 \\
$P_{2}$ & 26 & 32 & 22 & 48 & 60 & 36 \\
$P_{3}$ & & & & &
\end{tabular}

Os resultados da produção nos modos Modo I e Modo II são comparados na Tabela 3. A sua última linha apresenta as totalizações das quantidades de produtos produzidos pelos dois modos de produção. Saltam aos olhos a diferença destes valores a favor do Modo II. Trata-se de um exemplo típico onde os produtores atuam com independência, com máxima eficiência utilizando suas capacidades e recursos, para produzir quantidades de produtos que vão além do atendimento pleno de suas necessidades individuais, com possibilidade de trocas mútuas dos excedentes da produção auferida. E é exatamente neste aspecto que reside a base para a sustentação da comprovação do quinto princípio econômico aplicado neste exemplo:

- Existe uma combinação adequada de produtores PI, envolvidos num sistema econômico seus expertises e recursos disponíveis representados pelos seus planos $\Pi$ I de produção, com seus programas individuais de produção Si utilizados para 0 atendimento de suas próprias necessidades, onde $\mathrm{Si}=(\mathrm{JI}, \mathrm{NI}, \mathrm{KI}) \in \Pi \mathrm{I}$ tal que $0<\mathrm{JI}<\mathrm{Al}, \quad 0<\mathrm{NI}<\mathrm{BI}$ e $0<\mathrm{KI}<\mathrm{Cl}$, cujo somatório da produção de cada um deles é menor que o somatório da produção destes mesmos produtores PI quando eles executam os seus programas de produção $S^{*} ı € \Pi$ । baseados exclusivamente nas suas capacidades máximas individuais de produção de um único tipo de produto $\mathrm{PA}, \mathrm{PB}$ ou $\mathrm{Pc}$ com as respectivas quantidades $\mathrm{Al}, \mathrm{BI}$ ou $\mathrm{Cl}$. Estes últimos programas $S^{*} i=(A i, 0,0), S^{*} i=(0, B i, 0)$ ou $S^{*} i=(0,0, C i)$ estão especificamente baseados na máxima eficiência de cada produtor, conforme expressões (1.6) à (1.12), abaixo descritas.

\footnotetext{
4 No Modo I - Isolado, os produtores Pi estão efetivamente "escravizados" pelas suas próprias necessidades: para atendêlas, precisam se dedicar totalmente, não havendo tempo para produzir qualquer outra unidade adicional de produto. Nossas ontologias nos impedem de sermos eficientes em todos os processos que realizamos de forma isolada. No Modo I não há liberdade para maximizar eficiências.
} 
$\exists\left\{P_{i}\right\}_{i=1}^{n}$ produtores com planos $\Pi_{i}$ onde: $i=1, \cdots, n \mid i \neq j \neq k$ :

$$
\begin{aligned}
& \max \left\{A_{i}\right\}_{i=1}^{n}>\sum_{i=1}^{n} J_{i} \\
& \max \left\{B_{j}\right\}_{j=1}^{j \neq i}>\sum_{i=1}^{n} N_{i} \\
& \max \left\{C_{k}\right\}_{k \neq i}^{k \neq j}>\sum_{i=1}^{n} K_{i}
\end{aligned}
$$

$$
\left(\frac{1}{A_{i}} \cdot J_{i}+\frac{1}{B_{i}} \cdot N_{i}+\frac{1}{C_{i}} \cdot K_{i}\right)=1
$$

$$
\begin{gathered}
0<J_{i}<A_{i} \\
0<N_{i}<B_{i} \\
0<K_{i}<C_{i}
\end{gathered}
$$

- Quando a condição (1.6) e (1.8) ocorre, diz-se que efetivamente há a formação de excedentes de produção pela execução no Modo II. Sendo assim, tem-se que os excedentes da produção dos produtores Pı podem ser utilizados pelos próprios produtores para trocá-las entre si, visando atender suas necessidades pelos produtos que não produzem a custos efetivamente menores. A quantificação das produções totais no Modo II oferece a prova do princípio "Trocar é Bom!".

- Apesar de haver a possibilidade da existência de certas combinações de produtores PI onde as condições estabelecidas em (1.6) e (1.8) não são atendidas, tem-se que essas situações efetivamente não representam um sistema econômico, uma vez que as necessidades totais por produtos não seriam atendidas plenamente pela produção destes produtores: espera-se que os produtores (uma combinação adequada deles) sintam-se incentivados a produzir com programas individuais de produção $S^{*} ı \in \Pi$ ı onde suas capacidades máximas sejam efetivamente colocadas em prática. Este incentivo representa uma noção de ganho marginal, obtida pela observação que os produtores realizam sobre o sistema econômico-capturando sinalizações de mercado- a respeito de qual produto ele escolhe produzir com máxima eficiência para realizar comércio com os excedentes de produção auferidos. Apenas a combinação de produtores que produzem com eficiência para auferir excedentes de produção podem realizar trocas e comercializar, porque a efetivação dos ganhos marginais permite a materialização de vantagem comparativa para o comércio. O produtor que não materializa vantagem comparativa não participa efetivamente da combinação adequada de produtores que é esperada para comparar os resultados obtidos pelos programas Sı com S*I em um sistema econômico. As comparações ocorrem entre modos de produção de produtores eficientes.

A quarta e última etapa apresenta as comparações necessárias para que pelo menos uma das perguntas apresentadas no início desta seção seja respondida categoricamente no âmbito do exemplo apresentado, conforme Tabela 4. Objetiva-se comprovar a validade do quinto princípio econômico, cuja proposição se repete aqui como "Trocar é Bom!". 
Tabela 4 - Resultados da aplicação dos programas Sı e S*I do exemplo: Modo I e Modo II

\begin{tabular}{lcccr}
\hline \multirow{2}{*}{ Parâmetros de Análise } & \multicolumn{4}{c}{ Produtos produzidos $\left[\frac{\text { unid. }}{\text { dia }}\right]$} \\
& $P_{A}$ & $P_{B}$ & $P_{C}$ & Total \\
\hline Modo I & 26 & 32 & 22 & 80 \\
Modo II & 48 & 60 & 36 & 144 \\
Excedente de produção $\Delta$ & 22 & 28 & 14 & 64 \\
\hline \multirow{2}{*}{ Eficiência relativa $\Delta_{I \rightarrow I}^{\%}$} & $+84,6 \%$ & $+87,5 \%$ & $+63,6 \%$ & $+80,0 \%$ \\
Eficiência relativa $\Delta_{I \rightarrow I I}^{\%}$ & $-45,8 \%$ & $-46,6 \%$ & $-38,8 \%$ & $-44,4 \%$ \\
\hline
\end{tabular}

Em Engenharia, costuma-se comparar distintos processos entre si por meio de medidas de eficiência que estão associadas a determinados conjuntos de critérios previamente estabelecidos. Esses critérios regem as atividades de tomada de decisão que são necessárias para escolher quais processos, daqueles tomados em comparação, são considerados mais adequados para um certo propósito. Este costume (uma boa prática em Engenharia) será também utilizado na análise deste exemplo, com os seguintes elementos da Tabela 4:

- Os processos a serem comparados são os modos de produção Modo I e Modo II;

- O primeiro critério de comparação está definido pela "Medida de produtividade diária total" dos produtores, computadas por tipo de produto e total: estas medidas representam a produção total de itens que os produtores efetivamente realizam por dia de produção em cada modo (processo). Estas medidas estão quantificadas nas linhas um e dois da Tabela 4;

- O segundo critério de comparação está definido pela "Medida de excedente de produção" $\Delta$ : esta medida descreve a variação absoluta de produtividade diária total dos produtores, computadas por tipo de produto e total, considerada ente os modos de produção assumidos pelos produtores: Modo I e Modo II. Os valores de $\Delta$ estão na linha três da Tabela 4;

- O terceiro critério de comparação está definido pela "Medida de eficiência comparativa entre processos" $\Delta \% \| \rightarrow$ : esta medida de eficiência representa a medida de variação percentual entre as produtividades dos processos Modo I e Modo II, relativa ao Modo I. Esta medida descreve o quanto o processo Modo II é mais produtivo que o processo Modo I, em termos percentuais, dado que ambos consomem a mesma quantidade de recurso de tempo, que é 24 [horas/dia]. Valores positivos, nulos e negativos descrevem, respectivamente, eficiências relativas maiores, idênticas e menores entre os dois processos comparados, na linha quatro da Tabela 4;

- O quarto critério de comparação está definido pela "Medida de eficiência comparativa entre processos" $\Delta \% \mathrm{I} \rightarrow \mathrm{II}$ : esta medida de eficiência representa a medida de variação percentual entre as produtividades dos processos Modo I e Modo II, relativa ao Modo II. Esta medida de eficiência relativa descreve o quanto o processo Modo I é mais produtivo que o processo Modo II, em termos percentuais, dado que ambos consomem a mesma quantidade de recurso de tempo, que é que é 24 [horas/dia]. Seus valores estão na linha cinco da Tabela 4.

A partir dos dados reunidos nas representações pictóricas da Tabela 4 e da Figura 2 pode-se realizar as seguintes afirmações sobre o exemplo utilizado para descrever a 
comprovação do quinto princípio econômico: (i) Os produtores PI produziram quantidades diferentes dos produtos $\left\{\mathrm{PA}_{\mathrm{B}} \mathrm{PB}_{\mathrm{B}} \mathrm{PC}\right\}$ quando realizaram seus programas de produção Sı no Modo I e S*I no Modo II; (ii) Em todas as produções realizadas, o Modo II foi mais eficiente que o Modo I. Isso justifica os valores positivos para os excedentes de produção de cada um dos itens produzidos, refletindo-se também sobre a positividade dos valores de eficiência relativa $\Delta \% \mathrm{Il} \rightarrow \mathrm{I}$ do Modo II na produção dos três produtos dos três produtos.

O exemplo mostra que o Modo II é oitenta por cento mais eficiente que o Modo I. As cinco linhas da Tabela 4 e os quatro cartões $\{A B D ; B C F ; D G H ; F H I\}$ da Figura 2 estão em correspondência um-para-um, descrevem pictorialmente as mesmas medidas. A métrica denominada "Eficiência relativa" é calculada segundo expressões (1.13) e (1.14), abaixo.

Figura 2 - Análise comparativa entre os programas de produção Modo I e Modo II exemplificados.

$$
\begin{aligned}
& \Delta_{I I \rightarrow I}^{\% A}=\left[\frac{\sum_{i=1}^{n=3} J_{i}^{I I}-\sum_{i=1}^{n=3} J_{i}^{I}}{\sum_{i=1}^{n=3} J_{i}^{I}}\right] \cdot 100=\left[\frac{48-26}{26}\right] \cdot 100=+84,6 \% \\
& \Delta_{I \rightarrow I I}^{\% B}=\left[\frac{\sum_{i=1}^{n=3} N_{i}^{I}-\sum_{i=1}^{n=3} N_{i}^{I I}}{\sum_{i=1}^{n=3} N_{i}^{I I}}\right] \cdot 100=\left[\frac{32-60}{60}\right] \cdot 100=-46,6 \%
\end{aligned}
$$
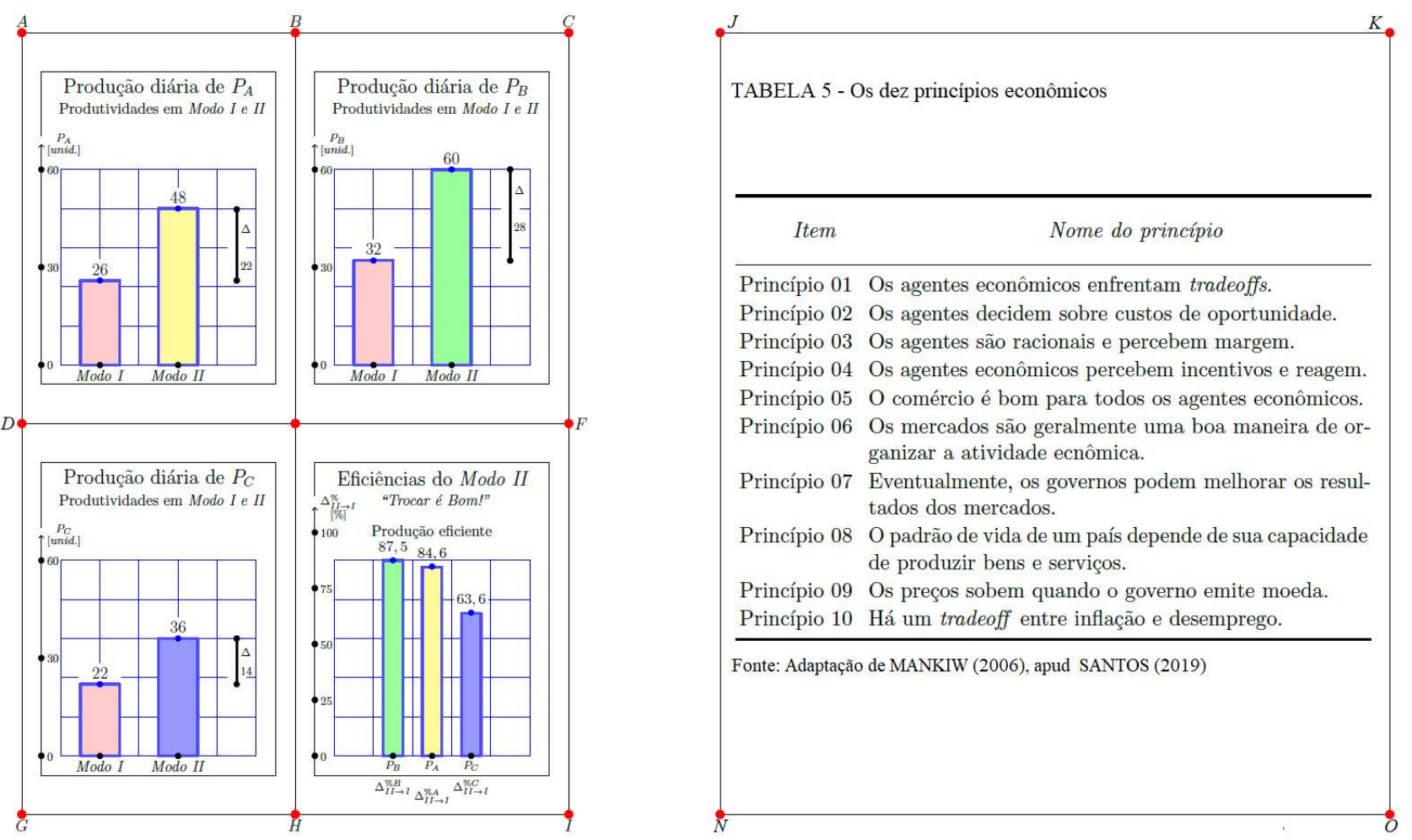

Existe uma causalidade associada aos resultados a favor do Modo II, descritos na Tabela 4 e Figura 2: toda vez que produtores organizam sua produção buscando maximizar suas eficiências individuais, o resultado para o sistema econômico formado por eles é caracterizado por efetiva eficiência global, originado pelo fato que este modo produz-se efetivos excedentes de produção. Os produtores com maior eficiência relativa possuem vantagem comparativa para realizarem comércio entre si. Assim, adquirem expertise para produzir, para atender suas necessidades e as necessidades do sistema econômico com os recursos que dispõem. Segundo Mankiw (2006), não se trata de uma coincidência. Assim, as respostas para as duas perguntas desta seção são, respectivamente, \{Sim; Não\}. Esta é a prova de que "Trocar é Bom!". A simplificação adotada levou em conta que este 
princípio foi provado no à revelia das discussões sobre os demais princípios econômicos descritos na Tabela 5. Isto foi feito propositadamente, pois há uma complexidade intrínseca no entendimento de qualquer fenômeno econômico sob a perspectiva das influências dos demais princípios que se evitou pelo uso do exemplo simplificado.

\section{REPRESENTAÇÃO ALTERNATIVA PARA O PLANO DE PRODUÇÃO Пı DO EXEMPLO}

O conjunto de pontos Sı $€$ Пı descrito na Figura 1 representa o nível eficiente ${ }^{5}$ da Fronteira de Possibilidades de Produção Пı do sistema estudado. Esta fronteira mostra as diversas possibilidades e combinações de produção que um sistema pode produzir com os fatores e as tecnologias produtivas que dispõe. Em 2D esta fronteira eficiente seria uma linha reta ou curva. Em 3D, ela pode ser um plano -como o próprio plano Пı do exemplo- ou uma superfície. Em dimensões maiores, esta fronteira seria descrita por um espaço vetorial de dimensão finita $\mathrm{Rn}$, com $\mathrm{n}>3$.

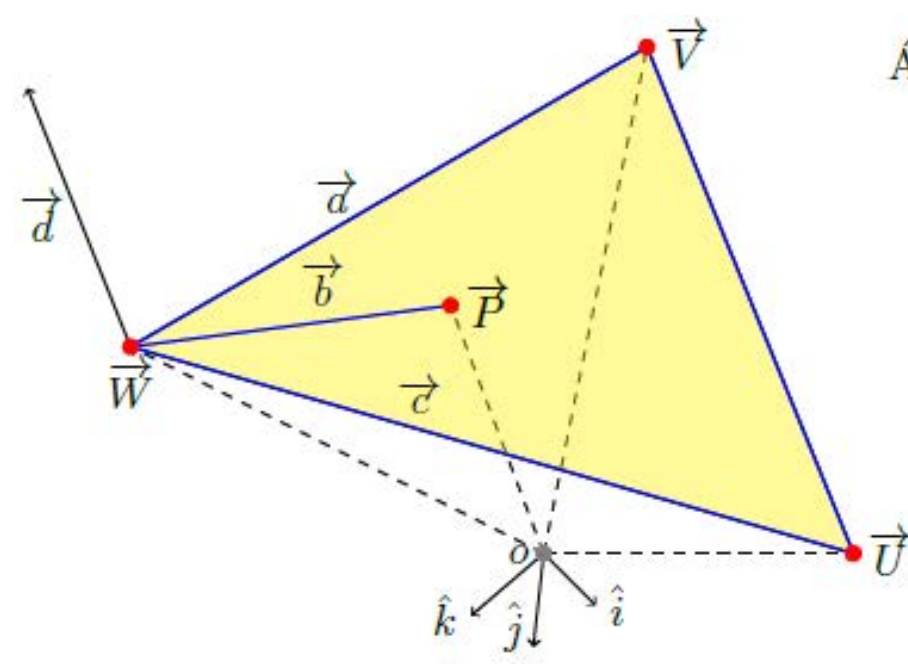

Álgebras vetoriais:

$$
\begin{array}{r}
\vec{U}=\left(U_{x} \cdot \hat{i}+U_{y} \cdot \hat{j}+U_{z} \cdot \hat{k}\right) \\
\vec{V}=\left(V_{x} \cdot \hat{i}+V_{y} \cdot \hat{j}+V_{z} \cdot \hat{k}\right) \\
\vec{W}=\left(W_{x} \cdot \hat{i}+W_{y} \cdot \hat{j}+W_{z} \cdot \hat{k}\right) \\
\vec{W}+\vec{a}=\vec{V} \\
\vec{W}+\vec{b}=\vec{P} \\
\vec{W}+\vec{c}=\vec{U}
\end{array}
$$

Uma forma alternativa para se determinar o conjunto de pontos Sı é utilizando-se operadores de Álgebra Linear, conforme Greenberg (1998) e Lipchutz (1994). Considere-se que sejam dados três pontos $\{U, V, W\} \in R^{n}$, localizados no ortante positivo de um espaço tridimensional e definidos os vetores $\{a, b, c, d\}$ como descritores do plano $\Pi$, conforme imagem e expressões (1.15) à (1.20) da Figura 3. Para garantir a pertinência de um vetor genérico $P$ ao plano $\Pi$ ı associam-se os vetores $\{a, b, c, d\}$ à direção perpendicular ao referido plano dada pelo produto vetorial expresso em (1.24) e à medida de perpendicularidade adequada dada pelo produto interno expresso em (1.25) ou (1.26). Substituindo-se os termos de (1.21) e de (1.23) em (1.24) tem-se a caracterização do vetor d que é perpendicular ao plano Пı , conforme descrito nas expressões (1.27) à (1.32). Uma vez tendo-se caracterizado o vetor direção d, pode-se exigir a sua condição de perpendicularidade com o plano Пı. Esta exigência está enunciada nas expressões (1.25) e (1.26).

As expressões (1.27) e (1.28) são uma decorrência de (1.24). A expressão (1.25) é reescrita abaixo pela substituição dos termos contidos nas expressões (1.22) e (1.29). As

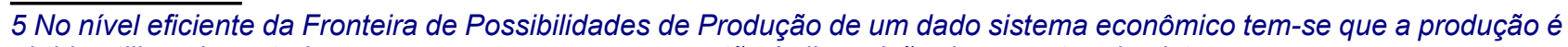
obtida utilizando-se todos os recursos escassos que estão à disposição dos agentes do sistema. 
projeções da medida de perpendicularidade exigida estão apresentada pelas expressões (1.33) à (1.36). Finalmente, tem-se a caracterização geométrica do plano Пı pela expressão (1.37) como uma representação alternativa -igualmente elegante- da expressão (1.2), na forma de sua descrição econômica do conceito de "Fronteira de Possibilidades de Produção".

$$
\begin{aligned}
& \text { onde: } \quad \vec{a}=\left(\left(V_{x}-W_{x}\right) \cdot \hat{i}+\left(V_{y}-W_{y}\right) \cdot \hat{j}+\left(V_{z}-W_{z}\right) \cdot \hat{k}\right) \\
& \vec{b}=\left(\left(P_{x}-W_{x}\right) \cdot \hat{i}+\left(P_{y}-W_{y}\right) \cdot \hat{j}+\left(P_{z}-W_{z}\right) \cdot \hat{k}\right) \\
& \vec{c}=\left(\left(U_{x}-W_{x}\right) \cdot \hat{i}+\left(U_{y}-W_{y}\right) \cdot \hat{j}+\left(U_{z}-W_{z}\right) \cdot \hat{k}\right) \\
& \vec{d}=\vec{c} \times \vec{a} \\
& \vec{b} \circ \vec{d}=0 \\
& \text { reescrevendo (1.25), tem-se: } \quad \vec{b} \circ(\vec{c} \times \vec{a})=0 \\
& \vec{d}=\vec{c} \times \vec{a}=\left|\begin{array}{ccc|cc}
i & j & k & i & j \\
c_{x} & c_{y} & c_{z} & c_{x} & c_{y} \\
a_{x} & a_{y} & a_{z} & a_{x} & a_{y}
\end{array}\right| \\
& \vec{d}=\vec{c} \times \vec{a}=\left|\begin{array}{ccc|cc}
i & j & k & i & j \\
\left(U_{x}-W_{x}\right) & \left(U_{y}-W_{y}\right) & \left(U_{z}-W_{z}\right) & \left(U_{x}-W_{x}\right) & \left(U_{y}-W_{y}\right) \\
\left(V_{x}-W_{x}\right) & \left(V_{y}-W_{y}\right) & \left(V_{z}-W_{z}\right) & \left(V_{x}-W_{x}\right) & \left(V_{y}-W_{y}\right)
\end{array}\right| \\
& \vec{d}=\left(d x \cdot \hat{i}+d_{y} \cdot \hat{j}+d_{z} \cdot \hat{k}\right) \\
& \text { onde: } \quad d_{x}=\left(\left(U_{y}-W_{y}\right) \cdot\left(V_{z}-W_{z}\right)-\left(V_{y}-W_{y}\right) \cdot\left(U_{z}-W_{z}\right)\right) \cdot \hat{i} \\
& d_{y}=\left(\left(U_{z}-W_{z}\right) \cdot\left(V_{x}-W_{x}\right)-\left(V_{z}-W_{z}\right) \cdot\left(U_{x}-W_{x}\right)\right) \cdot \hat{j} \\
& d_{z}=\left(\left(U_{x}-W_{x}\right) \cdot\left(V_{y}-W_{y}\right)-\left(V_{x}-W_{x}\right) \cdot\left(U_{y}-W_{y}\right)\right) \cdot \hat{k}
\end{aligned}
$$

\section{CONSIDERAÇÕES FINAIS}

O presente artigo objetivou destacar a validade do quinto princípio econômico denominado "O comércio é bom para todos" por meio de um pequeno exemplo utilizado para facilitar o entendimento deste objetivo, de forma simplificada e declarativa pelo termo "Trocar é Bom!". Assim, justifica-se o uso de um pequeno sistema econômico, tomado no exemplo, constituído por três produtores que assumem também o papel de consumidores de apenas três tipos de produtos. Obviamente, um sistema assim não existe no mundo real: ele pode apenas ser imaginado como possível para o entendimento do quinto princípio, que é aplicável sobre sistemas reais e muito mais complexos. O plano de produção Пı do exemplo é uma simplificação adequada para o conceito científico de "Fronteira de Possibilidades de Produção" que se busca apresentar aos alunos de Engenharia.

De acordo com Mankiw (2006), apud Santos (2019) os dez princípios descritos na Tabela 5 regem o fenômeno econômico em consideração. Eles explicam como as pessoas (famílias e instituições) tomam decisões, como elas interagem entre si e ainda explicam como a Economia de qualquer sociedade funciona. Eles ocorrem simultaneamente, estão sistemicamente integrados e indissociáveis, sendo considerados como verdadeiros marcadores do comportamento social das pessoas e das instituições que constituem nossa sociedade do jeito que ela realmente é hoje e do jeito como ela já foi no passado. São 
objetos das ciências Econômicas. Estes princípios também são objetos de estudos para a construção de políticas públicas adequadas ${ }^{6}$ que são responsáveis pelos projetos de transformação de nossa sociedade atual sob os aspectos de como ela deverá ser no futuro. Assim, por meio destes princípios, e dos esforços necessários para compreendê-los, tem-se uma ideia clara de como um fenômeno econômico é complexo. Segundo Miller (2013 e 2014), estes princípios assumem fundamental importância no pé "Econômico" do tripé da Sustentabilidade.

\section{REFERÊNCIAS}

GREENBERG, M. D. Advanced Engineering Mathematics. New Jersey: Prentice Hall, 1998.

LIPSCHUTZ, Seymour. Álgebra linear: teoria e problemas $-3^{\circ}$ edição. São Paulo: Makron Books, 1994. MANKIW, N. G. Introdução à Economia - $13^{\circ}$ edição. São Paulo: Thomson Learning, 2006.

MILLER, T. Constructing sustainability science: emerging perspectives and research trajectories. Sustain Sci 8, p. 279-293, doi.org: 10.1007/s11625-012-0180-6, 2013

MILLER, T. Reconstructing Sustainability Science: Knowledge and action for a sustainable future. The Earthscan Science in Society Series: Taylor \& Francis, 2014. Isbn 9781135960100.

SANTOS, A. M. Proposição de um algoritmo alternativo para a resolução do problema de Equilíbrio Espacial de Preços: Aspectos computacionais associados à representação matricial e Teoria dos Grafos. 1-156p. Tese (Doutorado), Florianópolis,/SC, PPGEP/UFSC, Brasil, 2019. 
O presente estudo realiza uma revisão da literatura a respeito do modelo Drum-buffer-rope (DBR) com foco na descrição e análise bibliométrica das publicações sobre a temática em periódicos de 1988 até maio de 2020. A amostra de 117 trabalhos foi obtida por meio da base de dados Scopus e os dados foram analisados com uso de planilhas e do software Vosviewer para a geração de redes e clusters. A análise descritiva inicial evidenciou o crescimento de estudos na área ao longo dos anos, os principais autores, revistas e países que têm contribuído para a discussão do tema. A análise de redes abrangeu três óticas: palavras-chave, citação e cocitação. Foi possível a compreensão das relações entre os estudos sobre a temática ao longo do tempo, a identificação dos termos mais representativos da área, as publicações mais citadas e as contribuições dessas e os grupos de trabalhos e autores citados conjuntamente por outras pesquisas. Desse modo, os resultados do trabalho devem permitir a identificação de oportunidades de pesquisas, assim como, fundamentar o desenvolvimento de novos artigos sobre o modelo de programação e controle DBR.

Palavras-chave: drum-buffer-rope. revisão da literatura. DBR. bibliometria.

\section{Alistipat}

The present study performs a literature review about the drum-buffer-rope (DBR) model doing a description and bibliometric analysis of publications and the subject in journals from 1988 to may 2020. The sample of 117 papers was obtained through Scopus database and analyzed using spreadsheets and the Vosviewer software for the generation of networks and clusters. The initial descriptive analysis showed the growth of studies in the subject over the years, the main authors, journals and countries that have contributed to the discussion of the topic. network analysis covered three perspectives: keywords, quotation and cocitation. It was possible to understand the relationships between studies on the subject over time, the identification of the most representative terms in the area, the most cited publications and their contributions and the groups of works and authors cited jointly by other researches. In this way, the results of the work should allow the identification of research opportunities, as well as, support the development of new papers on the DBR programming and control model.

Keywords: drum-buffer-rope. literature review. DBR. bibliometric. 


\section{INTRODUÇÃO}

Frente a crescente incerteza da economia e a competitividade, as organizações vêm buscando alternativas capazes de incrementar os ganhos. Nesse âmbito, a Teoria das Restrições (Theory of Constraints) ou TOC possui notável destaque por promover melhorias nos resultados nas empresas. Seguindo essa lógica, surge o DBR (Drum-Buffer-Rope ou Tambor-Pulmão-Corda) como método de programação e controle da produção focado no gerenciamento de restrições, sejam estas físicas e/ou do mercado (WATSON et al., 2007).

Em 1988, Eliyahu M. Goldratt publicou o primeiro trabalho em periódico acerca dessa temática, intitulado "Computerized shop floor scheduling". A partir da primeira publicação surgiram revisões da literatura com o objetivo de fornecer mais embasamento teórico sobre a temática. Blackstone Jr e Cox III (2002) realizaram levantamento com relação aos projetos da teoria das restrições e gerenciamento de linhas desbalanceadas. Ikeziri et al. (2016) e, posteriormente, Ikeziri et al. (2018) conduziram uma revisão abrangente sobre os métodos que compõem a TOC. Por fim, Silva e Mesquita (2019) apresentam uma revisão acerca do DBR direcionado a produtividade com uma amostra delimitada ao período de 2008 a 2018.

Nesse sentido, o presente trabalho contribui com a apresentação de uma revisão da literatura sobre DBR, focada em publicações em periódicos internacionais nos últimos 32 anos (1988 a maio/2020). O trabalho contempla uma análise descritiva das publicações, seguida por uma análise bibliométrica a fim de identificar os principais autores, produções científicas mais relevantes e a avaliar relações entre as pesquisas desenvolvidas.

A pesquisa está estruturada em seis seções, sendo a segunda um breve referencial teórico da temática, seguida pelo método e a análise descritiva da literatura. A quinta seção apresenta a análise das redes e a sexta seção consiste nas considerações finais do trabalho.

\section{DRUM-BUFFER-ROPE (DBR)}

De acordo Thürer et al. (2017), o Drum- Buffer- Rope evidencia-se como um importante elemento de programação e controle da produção da TOC. Nesse conceito, os recursos que se caracterizam como não-restritivos, localizados antes do gargalo, são subordinados a restrição, enquanto os instalados após gargalo produzem de maneira empurrada por dispor de uma capacidade superior (CHAKRAVORTY; ATWATER, 2005).

O primeiro componente do DBR, tambor (drum), caracteriza a restrição do sistema que determina o ritmo de produção, isto é, o gargalo. O segundo, o pulmão (buffer) representa o estoque, que deve garantir que o gargalo trabalhe sem interrupções. Já a corda (rope) realiza a subordinação para a liberação de ordens (SCHRAGENHEIM; RONEN, 1990).

Tais conceitos possibilitam que a complexidade do fluxo de materiais seja mais compreensível, de modo a reduzir o número de recursos que devem ser programados. Por fim, Souza (2005) destaca o Drum-Buffer-Rope como uma proposta para programação e 
controle da produção com excelentes resultados práticos, capaz de promover uma melhoria contínua.

\section{MÉTODO DA PESQUISA}

O presente estudo possui natureza básica, abordagem predominantemente qualitativa e pode ser caracterizado como uma pesquisa exploratória. A revisão da literatura oferece ao pesquisador o mapeamento e a avaliação da estrutura de conhecimento a respeito de um determinado tema, fronteiras de pesquisa e lacunas a serem exploradas (TRANFIELD; DENYER; SMART, 2003).

A amostra da pesquisa contempla estudos publicados em periódicos indexados na base de dados Scopus, sendo limitada a publicações no idioma inglês. A referida base de dados é uma das mais representativas da área de engenharia, tendo sido utilizada por pesquisas (IKEZIRI et al., 2016). A seleção da amostra foi feita com a busca da palavra-chave "Drum Buffer Rope". A escolha da palavra se deu após o teste de algumas combinações de termos que representassem a bem temática e resultassem em uma amostra consistente.

Obteve-se um total de 117 resultados, que estavam de acordo com os parâmetros. O período de análise abrange o intervalo de 1988 (primeira publicação) a maio de 2020 (mês de coleta de dados). Após a consolidação da amostra, foi realizada uma análise descritiva, a fim de caracterizar o âmbito de pesquisa com o suporte de planilhas e em seguida, a análise de redes de palavras-chave, citações e cocitações. Os estudos foram exportados da Scopus para o software VosViewer, de modo a servir como base para a geração de redes e clusters (seção 5).

\section{ANÁLISE DESCRITIVA INICIAL}

Para a análise descritiva, avaliou-se os 117 artigos quanto ao número de publicações por ano, autores mais ativos, principais revistas e países. A Figura 1 apresenta, em azul, o total de artigos publicados por ano, enquanto a linha verde representa os valores acumulados. Foram aproximadamente 32 anos de publicações, sendo nos anos de 2008, 2010 e 2015 que se concentram 20,51\% da amostra estudada. Vale destacar que após a morte Goldratt em 2011 houve diminuição no número de trabalhos. Apesar disso, a partir do ano de 2015 , notou-se que tendência de crescimento voltou a ter comportamento semeIhante aos anos anteriores. 
Figura 1 - Publicações por ano

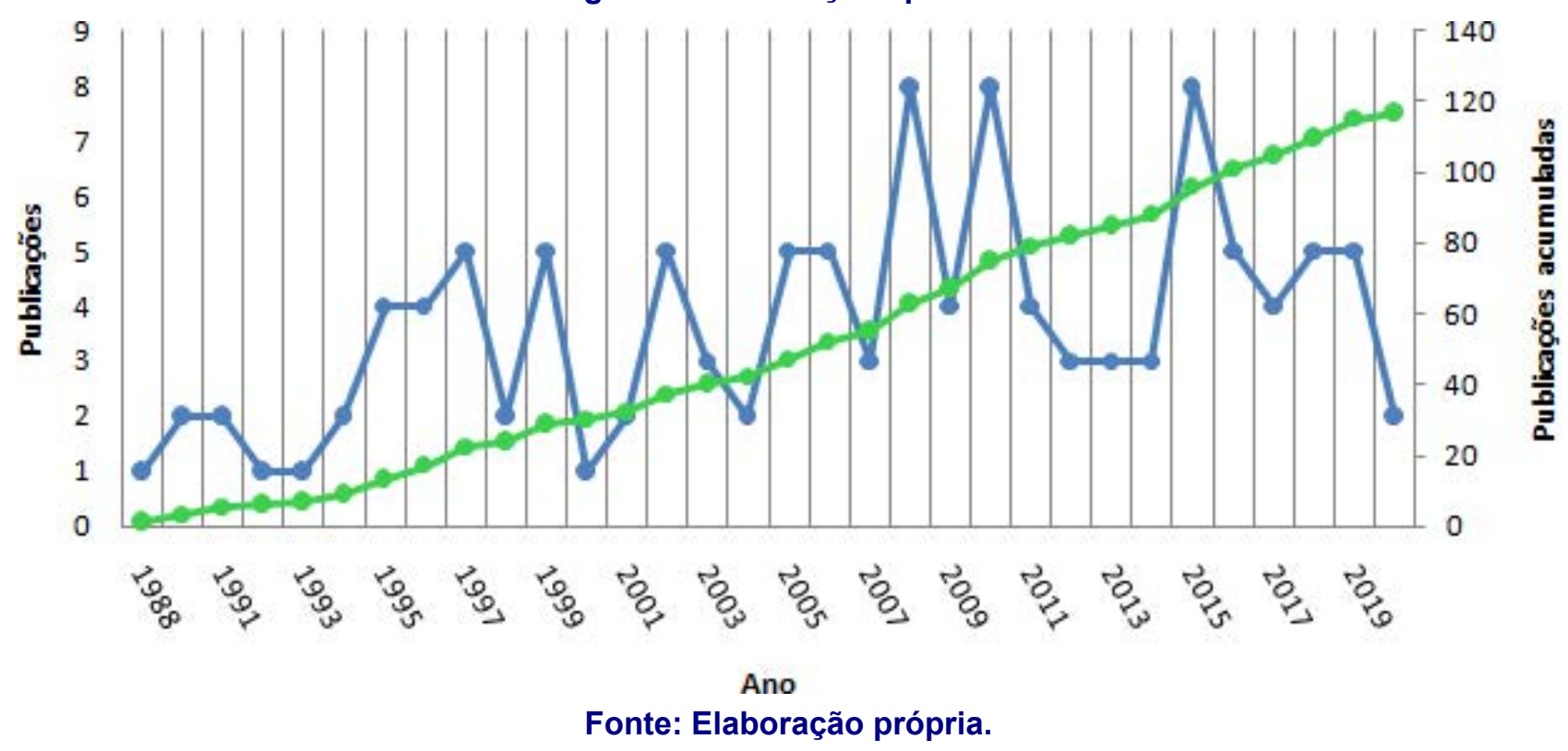

Em relação à contribuição dos autores para a discussão da temática, observa-se que os que mais publicaram no período analisado foram S. S. Chakravorty, J. F. Cox, M. Stevenson e M. Thürer com cinco publicações cada um e B. Ronen e H. Wu com quatro publicações cada. Destes, Ronen, Cox, Chakravorty e Wu são os que publicam trabalhos há mais tempo, com maior concentração em meados das décadas de 1990 e de 2000. Thürer e Stevenson, por sua vez, têm seus trabalhos publicados desde a segunda metade da década de 2010.

Dentre os artigos pesquisados, 68 artigos (58,12\%), concentram-se em 8 dos 52 periódicos. O International Journal of Production Research (IJPR) publicou $24,79 \%$ da amostra, se destacando como o principal canal para publicações. Esse comportamento é condizente com as observações feitas por Ikeziri (2016) na revisão sobre a TOC. Em seguida, os dois periódicos com maior número de publicações (9 cada) são International Journal of Production Economics (IJPE) e Production Planning and Control (PPC). Na sequência temse: Production and Inventory Management Journal (6), Expert Systems with Applications (5), Computers and Industrial Engineering (4), Production and Operations Management (3) e World Academy of Science, Engineering and Technology (3). Observa-se que 49 artigos $(41,88 \%)$ estão contidos em 44 periódicos, o que sugere uma alta disseminação do tema.

Em relação aos países de origem das publicações, o Estados Unidos é o país com maior número de publicações (34\%), seguido por Taiwan (8,67\%) e China $(7,33 \%)$. O Brasil, com 2,67\%, ocupa a nona posição com 4 artigos publicados.

\section{ANÁLISE DE REDES}

\section{Palavras-chave}

Para a compreensão das principais palavras-chave utilizadas nos estudos dedicados ao sistema DBR, realizou-se uma análise de redes com o VosViewer. O parâmetro de entrada foi a ocorrência mínima de 5 vezes para cada palavra. Ressalta-se que não foram 
excluídas da amostra as palavras de similares, como por exemplo, "drum-buffer-rope" e "DBR".

Ao verificar a ocorrência das palavras-chave na literatura ao longo dos anos, constatou-se que palavras como "workload control" se tornaram mais presente nos estudos recentes (após 2015), assim como, "supply chain management" predomina em estudos na última década. Já termos que remetem ao controle de estoques e da produção e modelagem são predominantes desde os anos 2000 por se referirem a uma literatura mais consolidada.

Como esperado, as palavras mais representativas (maiores esferas) são o termo utilizado na busca e outras que caracterizam a função e origem do modelo, como: Teoria das Restrições, corda, programação e controle da produção. Demonstrou-se a existência de cinco clusters na rede, como pode-se observar na Figura 2.

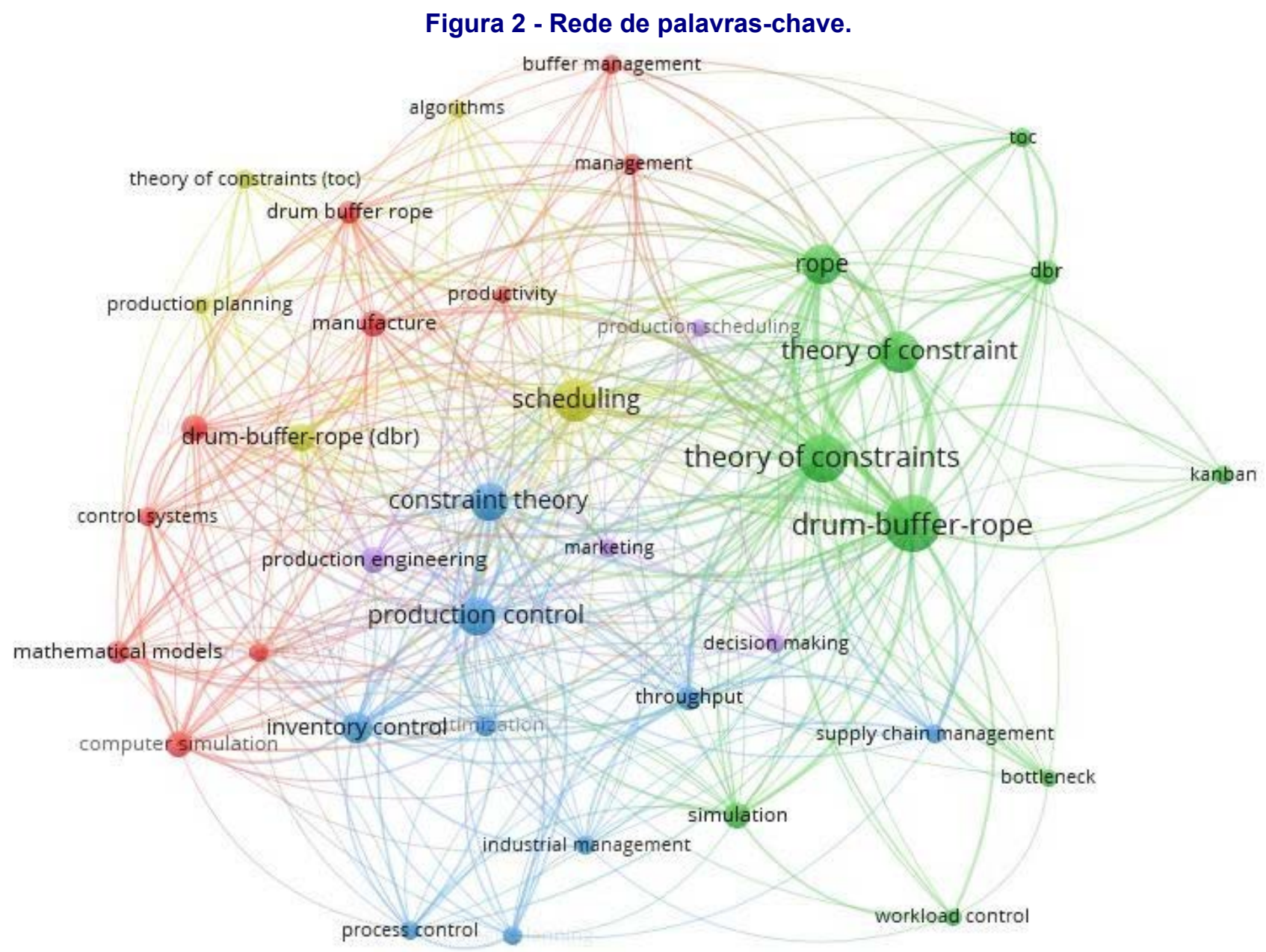

Fonte: Elaboração própria.

O cluster vermelho conecta estudos da área de gerenciamento do pulmão, que muitas vezes são discutidos com o uso de modelagens e simulações. Congrega, ainda, discussões sobre produtividade, planejamento, gerenciamento e controle da manufatura. $\mathrm{O}$ cluster verde também se utiliza da simulação para análise de gargalos, entretanto voltado para o desempenho do DBR em conjunto ou comparação com outros modelos.

O grupo azul diz respeito ao conglomerado de palavras utilizadas para tratar de aspectos macro de gestão como cadeia de suprimentos, planejamento estratégico, controle da produção e controle de estoques. O cluster amarelo é composto por palavras relacio- 
nadas a estudos que se utilizam de algoritmos matemáticos para otimizar a programação da produção para cada etapa do processo observado. O grupo lilás, assim como o cluster azul, corresponde a estudos mais gerais a respeito do tema, com enfoque na tomada de decisão na gestão fabril.

\section{Citação}

Elaborou-se uma rede de citações de artigos (Figura 3) com intuito de identificar os estudos que apresentavam um maior impacto na área de conhecimento do modelo DBR. Para geração da rede, utilizou-se como parâmetro o mínimo de 5 citações por documento.

Para uma melhor compreensão da rede, adotou-se um sistema de visualização com escala de cores de acordo com a linha temporal de publicação, onde a cor lilás identifica os estudos clássicos da área e a cor amarela aponta as pesquisas mais recentes. Vale destacar que esse último grupo, em especial, apresenta uma notável presença na rede. Esse cenário pode ocorrer por ser comum citar artigos contemporâneos para caracterizar a problemática. Além disso, ao destacar os fundamentos da teoria, os estudos mais recentes também se conectam com os trabalhos clássicos.

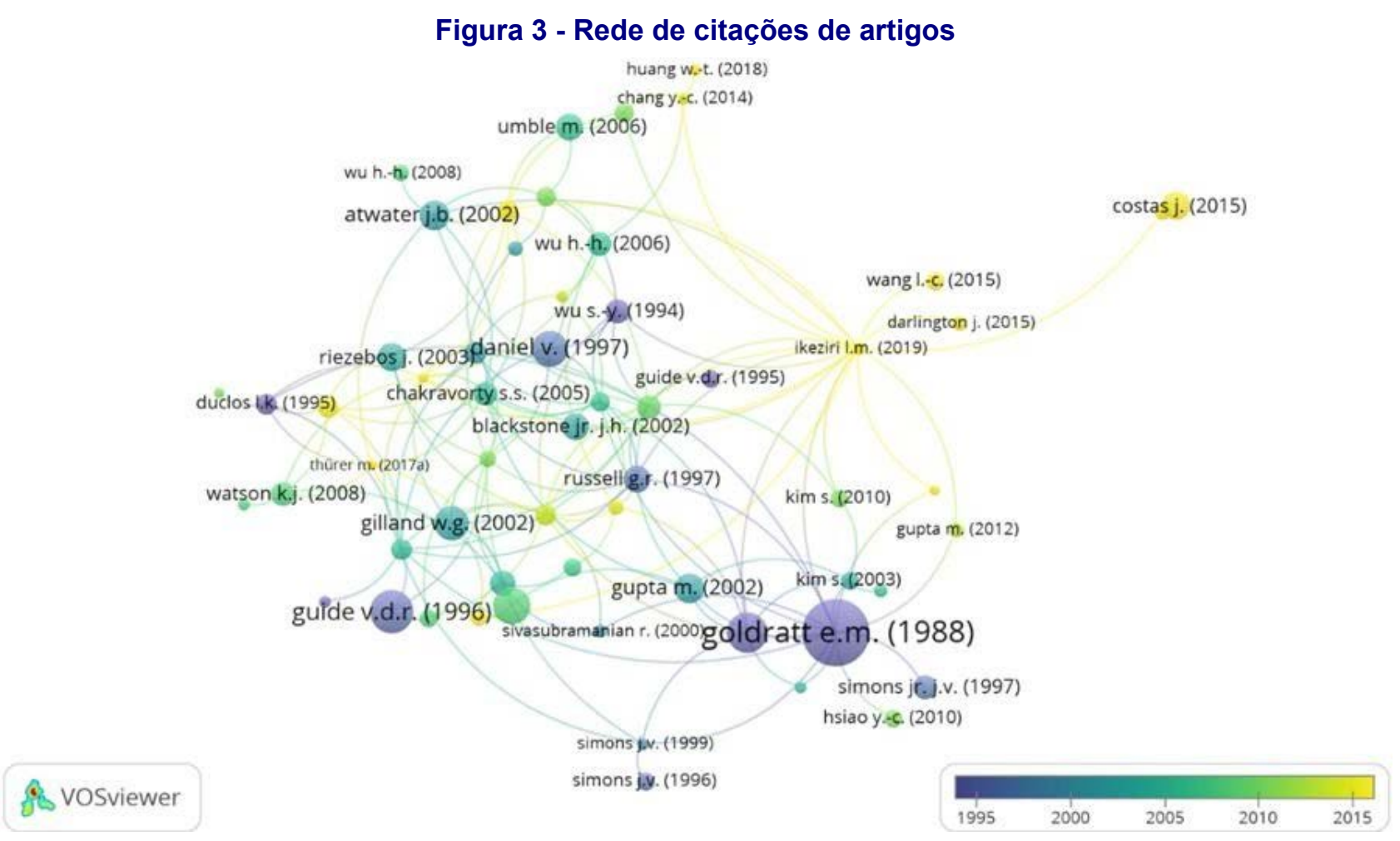

Fonte: Elaboração própria.

O Quadro 1 (Apêndice A) complementa a análise com um ranking dos 20 trabaIhos que apresentaram um maior número de citações na rede (dados da Scopus). Nota-se que Goldratt (1988) detém maior quantidade, seguido por Guide (1996) e Ronen e Martin (1990). Ademais, verificou-se que a IJPR se mostra como a principal fonte de publicação dos artigos mais citados. Em seguida, observa-se a IJPE, demonstrando o papel essencial dessas na disseminação do DBR, em consonância com lkeziri et al. (2018). 


\section{Cocitação}

Para extração dos dados associados a cocitação, foi determinado como tipologia da análise a cocitação de referências e, em seguida, a de autores. Determinou-se o número mínimo de 4 citações para uma referência. A partir de tal escopo, doze trabalhos correspondiam aos parâmetros, considerando a base de 2957 referências documentadas nos artigos e revisões analisados, além da identificação de três clusters (Figura 4).

O primeiro cluster, identificado pela cor vermelha, possui trabalhos de Chakravorty (2001), Gupta e Snyder (2009), Luebbe e Finch (1992), Spearman et al. (1990) e Watson e Patti (2008). Todos os estudos que pertencem a esse agrupamento comparam o DBR com outros modelos ou métodos, como programação linear, Just in time (JIT), CONWIP etc.

O segundo cluster, em verde na rede, apresenta dois trabalhos de Goldratt, Schragenheim e Ronen (1991) e Simatupang; Wright e Sridharan (2004). Tal agrupamento considera fundamentos da literatura como o livro "The Race", onde Goldratt comenta o DBR, o primeiro artigo de periódico publicado sobre a temática e outros dois textos clássicos para compreensão do modelo e suas extensões na produção e na cadeia de suprimentos.

Por fim, o cluster azul possui como trabalhos Atwater e Chakravorty (2002), Radovilsky (1998) e Russell (1997). Esse remete a artigos que abordam o funcionamento do pulmão e a corda, seja por meio do estudo do dimensionamento do buffer (RADOVILSKY, 1998) ou de regras para liberação (RUSSELL, 1997), assim como, a verificação da capacidade protetiva e o controle da liberação (ATWATER; CHAKRAVORTY, 2002).

Figura 4 - Rede de cocitação por referência.

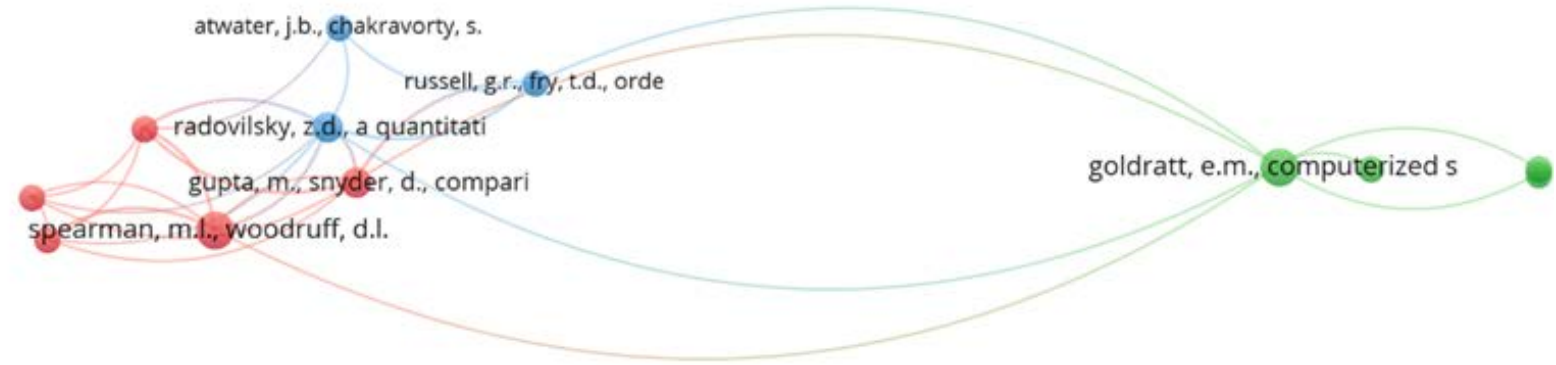

Fonte: Elaboração própria.

Ao considerar cocitação como o tipo de análise, porém com autores citados como unidade para parametrizar os dados, foi possível elaborar a Figura 5. Para tanto, foi definido o número mínimo de citação por autor como 15, resultando em 4 clusters. A partir da análise foi possível identificar uma falha na leitura dos dados pelo VosViewer, já que caracteres especiais e padrões de escrita não são identificados com facilidade e podem gerar duplicidade.

Ainda assim, com a rede oferecida pelo software é possível inferir que Goldratt é o autor com maior relevância. Outra observação quanto ao cluster que Goldratt encontra-se é a de que o mesmo apresenta os autores de trabalhos clássicos acerca do DBR. Observa-se também, em alguns casos, a ligação entre autores que fizeram estudos em conjunto como Mabin e Balderstone. Seguindo as mesmas características identificadas anteriormente, o cluster azul é composto por autores tradicionais com grande influência na produção de arti- 
gos sobre o tema, sobretudo apresenta autores com publicações relevantes anteriores até meados de 2005.

No que tange ao cluster verde, pode-se compreender que os autores que compõem este agrupamento são responsáveis por pesquisas publicadas mais recentemente. No entanto, observa-se a relação desses com a citação de autores que publicaram há bastante tempo como Baker, que desde a década de 70 publica sobre programação da produção, e Philipoom. Por sua vez, o cluster amarelo, demonstra uma menor representação de ligações e esferas de tamanho menos relevante quando comparado às conexões estabelecidas na rede. Visto isso, os autores desta tribo dissertam sobre outros métodos, relacionando-os com o DBR.

Figura 5 - Rede de cocitação por autor.

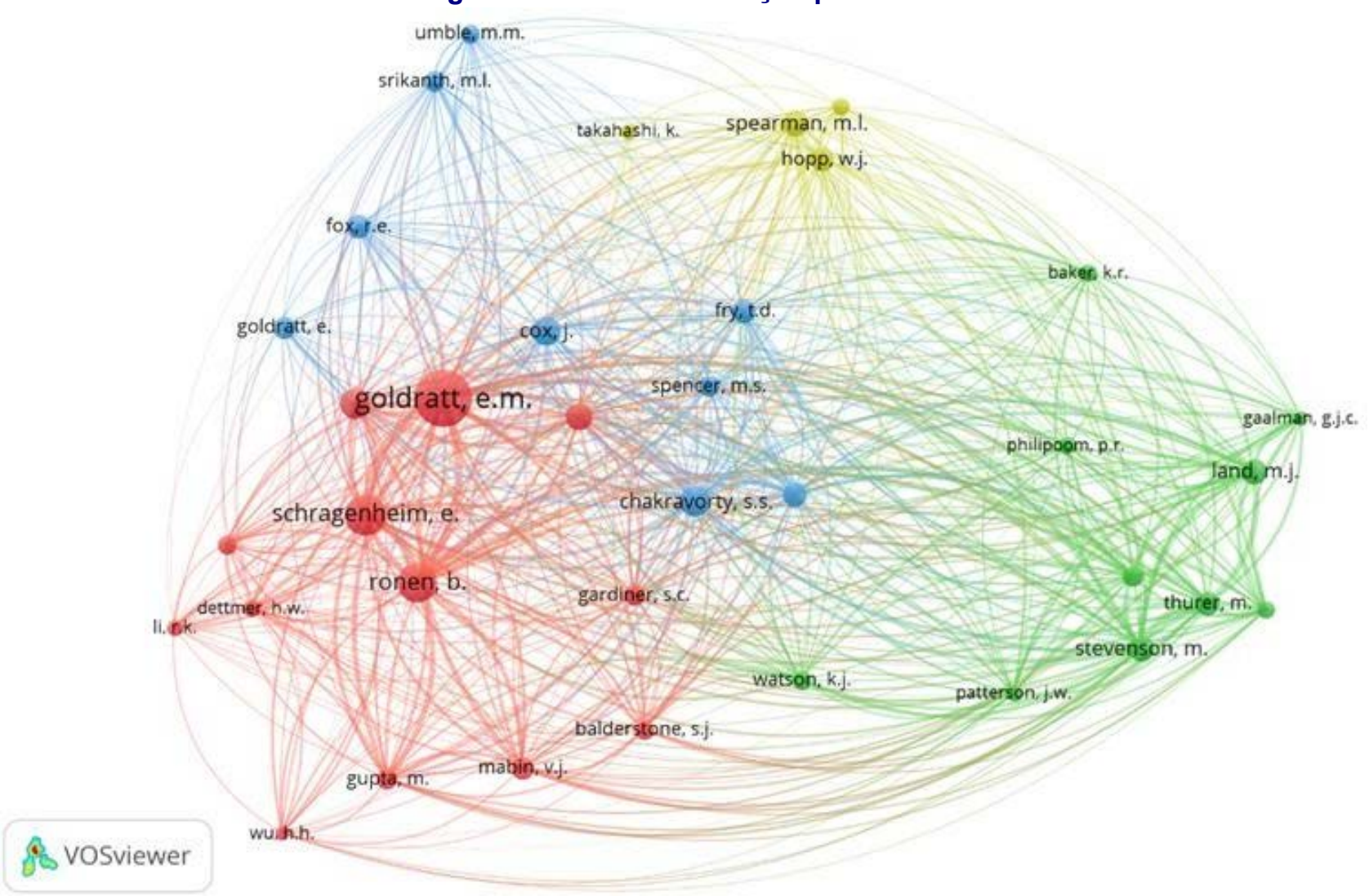

Fonte: Elaboração própria.

\section{CONSIDERAÇÕES FINAIS}

Diante do objetivo de apresentar uma revisão da literatura sobre o DBR, o presente artigo realizou a análise de 117 publicações em periódicos internacionais no período de 1988 a maio/2020. Tal análise possibilitou a identificação dos principais autores, as produções científicas mais relevantes mediante a avaliação das citações, as palavras-chaves mais abordadas e a relação entre os principais trabalhos e os respectivos autores. Como resultados, pode-se destacar a elaboração de um ranking dos 20 trabalhos com o maior número de citações e o detalhamento das contribuições das publicações.

Algumas limitações restringiram em partes o avanço dos resultados. Inicialmente, o artigo estava pautado na união de duas bases de dados - Scopus e Web of Science - po- 
rém, por dificuldades nos processos de unificação dos bancos, a pesquisa prosseguiu com uma base. Mesmo assim, acredita-se que a amostra é representativa e que os artigos não contemplados representam uma pequena parcela do total estudado.

Ademais, evidencia-se a importância da revisão da literatura realizada, uma vez que, dentre os resultados obtidos por meio da análise dos clusters, é possível mapear as produções sobre a temática do DBR, auxiliando o direcionamento das próximas pesquisas. Nesse sentido, como sugestão de trabalhos futuros, pode-se explorar a revisão da literatura de variações do modelo como o Simplified Drum-Buffer-Rope. Assim como, dar continuidade a presente revisão a fim de identificar fases da literatura, os setores de aplicação e um detalhamento maior dos clusters de citações.

\section{REFERÊNCIAS}

ATWATER, J. B.; CHAKRAVORTY, S. S. A study of utilization of capacity constrained resources in drum-buffer-rope systems. Production and Operations Management, v. 11, n. 2, p. 259-273, 2002.

BETTERTON, C. E.; COX III, J. F. Espoused drum-buffer-rope flow control in serial lines: A comparative study of simulation models. International Journal of Production Economics, v. 117, n. 1, p. 66-79, 2009.

BLACKSTONE JR, J. H.; COX III, J. F. Designing unbalanced lines - understanding protective capacity and protective inventory. Production Planning \& Control, v. 13, n. 4, p.416-423, 2002.

CHAKRAVORTY, S. S. An evaluation of the DBR control mechanism in a job shop environment. Omega, v. 29, n. 4, p. 335-342, 2001.

CHAKRAVORTY, S. S.; ATWATER, J. B. The impact of free goods on the performance of drumbuffer-rope scheduling systems. International Journal of Production Economics, v. 95, n. 3, p. 347-357, 2005.

COSTAS, J.; PONTE, B.; FUENTE, D.; PINO, R.; PUCHE, J. Applying Goldratt's Theory of Constraints to reduce the Bullwhip Effect through agent-based modeling. Expert Systems with Applications, v. 42, n. 4, p. 2049-2060, 2015.

DANIEL, V.; GUIDE JR , R. Scheduling with priority dispatching rules and drum-buffer- rope in a recoverable manufacturing system. International Journal of Production Economics, v. 53, n. 1, p. 101-116, 1997.

GILLAND, W. G. A simulation study comparing performance of CONWIP and bottleneck- based release rules. Production Planning \& Control, v. 13, n. 2, p. 211-219, 2002.

GOLDRATT, E. M.; COX, J. The goal: excellence in manufacturing. New York: North River Press, 1984.

GOLDRATT, E.M. Computerized shop floor scheduling. International Journal of Production Research, v. 26, n. 3, p. 443-455, 1988.

GUIDE Jr, V. D. R. Scheduling using drum-buffer-rope in a remanufacturing environment.

International Journal of Production Research, v. 34, n.4, p. 1081-1091, 1996.

GUPTA, M.; HYUN-JEUNG, K.; HOKEY, M. TOC-based performance measures and five focusing steps in a job-shop manufacturing environment. International Journal of Production Research, $v$. 40, n. 4, p. 907-930, 2002. 
GUPTA, M.; SNYDER, D. Comparing TOC with MRP and JIT: a literature review. International Journal of Production Research, v. 47, n. 13, p. 3705-3739, 2009.

IKEZIRI, L.M; FIORINI, P.C; SOUZA, F.B. Teoria das restrições: evolução histórica e uma análise bibliométrica. In: Simpósio de Engenharia de Produção (SIMPEP), 2016, 26, São Paulo. Anais... São Paulo: SIMPEP, 2016. p. 1-14.

IKEZIRI, L.M; SOUZA, F.B.; GUPTA, M.C.; FIORINI, P.C. Theory of constraints: review and bibliometric analysis. International Journal of Production Research, v. 57, n. 15-16, p.5068-5102, 2018.

JODLBAUER, H.; HUBER, A. Service-level performance of MRP, kanban, CONWIP and DBR due to parameter stability and environmental robustness. International Journal of Production Economics, v. 46, n. 8, p. 2179-2195, 2008.

$\mathrm{KOH}$, S. -G.; BULFIN, R. L. Comparison of DBR with CONWIP in an unbalanced production line with three stations. International Journal of Production Research, v. 42, n. 2, p. 391-404, 2004.

LUEBBE, R.; FINCH B. Theory of constraints and linear programming: a comparison. International Journal of Production Research, v. 30, n. 6, p.1471-1478, 1992.

RADOVILSKY, Z. D. A quantitative approach to estimate the size of the time buffer in the theory of constraints. International Journal of Production Economics, v. 55, n. 2, p. 113- 119, 1998.

RIEZEBOS, J.; KORTE, G. J.; LAND, M. J. Improving a practical DBR buffering approach using Workload Control. International Journal of Production Research, v. 46, n. 8, p. 2179-2195, 2003.

RONEN, B.; MARTIN, K. S. Synchronized manufacturing as in OPT: from practice to theory. Computers \& Industrial Engineering, v. 18, n. 4, p. 585-600, 1990.

RUSSEL, G. R.; FRY, T. D. Order review/release and lot splitting in drum-buffer-rope. International Journal of Production Research, v. 35, n. 3, p. 827-845, 1997.

SCHRAGENHEIM, E.; RONEN, B. Drum-buffer-rope shop floor control. Production and Inventory Management Journal, v. 31, n. 3, p. 18-22, 1990.

SCHRAGENHEIM, E.; RONEN, B. Buffer management: a diagnostic tool for production control. Production and Inventory Management Journal, v. 32, n. 2, p. 74-79, 1991.

SILVA, B. C.; MESQUITA, M. A. Aplicação do método tambor- pulmão-corda: revisão e análise bibliométrica. In: Simpósio de Engenharia de Produção (SIMPEP), 2019, 26, São Paulo. Anais... São Paulo: SIMPEP, 2019. p. 1-14.

SIMATUPANG, T. M.; WRIGHT, A. C.; SRIDHARAN, R. Applying the theory of constraints to supply chain collaboration, Supply Chain Management, v. 9, n. 1, p. 57-70, 2004.

SIMONS JR., J. V.; SIMPSON III, W. P. An Exposition of Multiple Constraint Scheduling As Implemented in the Goal System (Formerly Disaster). Production and Operations Management, v. 6, n. 1, p. 3-22, 1997.

SOUZA, F. B. Do OPT à Teoria das Restrições: avanços e mitos. Production, v. 15, n. 2, p. 184197, 2005.

SPEARMAN, M.; WOODRUFF, D.; HOPP, W. CONWIP: a pull alternative to kanban. International Journal of Production Research, v. 28, n. 5, p. 879-894, 1990.

TRANFIELD, D.; DENYER, D.; SMART, P. Towards a methodology for developing evidence informed management knowledge by means of systematic review. British journal of management, v. 14, n. 3, p. 207-222, 2003.

UMBLE, M.; UMBLE, E.; MURAKAMI, S. Implementing theory of constraints in a traditional 
Japanese manufacturing environment: The case of Hitachi Tool Engineering. International Journal of Production Research, v. 44, n. 10, p. 1863-1880, 2006.

THÜRER, M.; QU, T.; STEVENSON, M.; LI, C. D.; HUANG, G. Q. Deconstructing bottleneck shiftiness: the impact of bottleneck position on order release control in pure flow shops. Production Planning \& Control, v. 28, n. 15, p. 1223-1235, 2017a.

WATSON, K. J.; BLACKSTONE, J. H.; GARDINER, S. C. The evolution of a management philosophy: the theory of constraints, Journal of Operations Management, n.25, p.387-402, 2007.

WATSON, K. J.; PATTI, A. A comparison of JIT and TOC buffering philosophies on system performance with unplanned machine downtime. International Journal of Production Research, v. 46, n. 7, p. 1869-1885, 2008.

WU, H.-H.; YEH, M. -L. A DBR scheduling method for manufacturing environments with bottleneck re-entrant flow. International Journal of Production Research, v. 44, n. 5, p. 883-902, 2006.

WU, S-Y.; MORRIS, J. S.; GORDON, T. M. A simulation analysis of the effectiveness of drumbuffer-rope scheduling in furniture manufacturing. Computers \& Industrial Engineering, v. 26, n. 4, p. 757-746, 1994. 


\begin{tabular}{|c|c|c|c|c|c|c|c|c|c|c|c|c|c|}
\hline \multirow{7}{*}{ 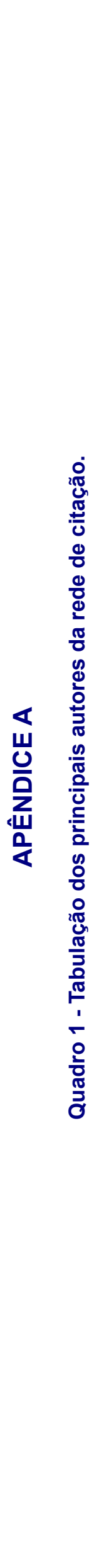 } & 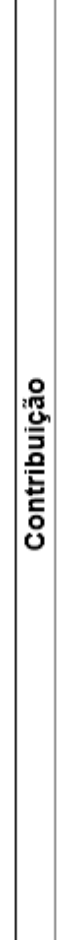 & 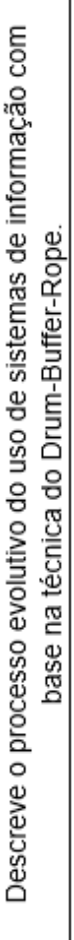 & 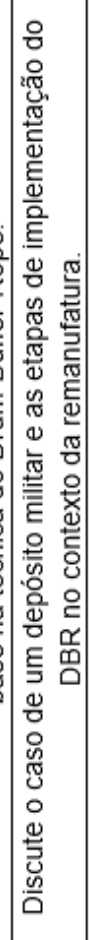 & 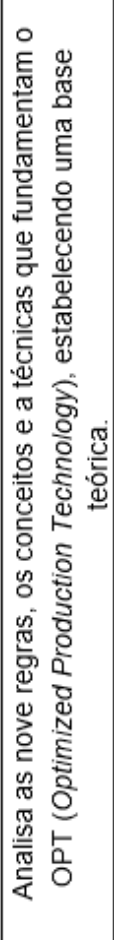 & 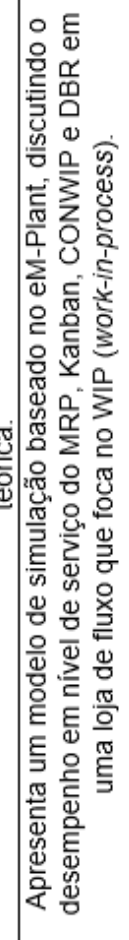 & 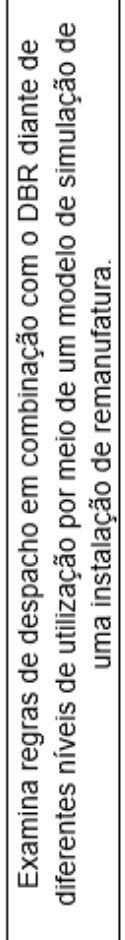 & 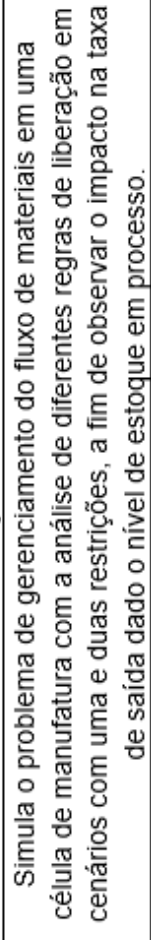 & 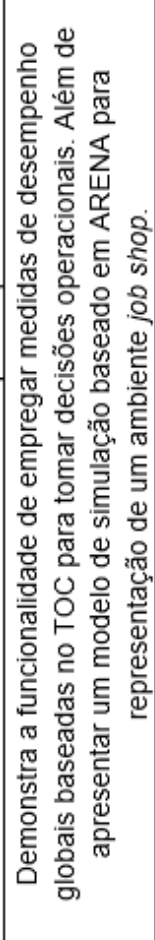 & 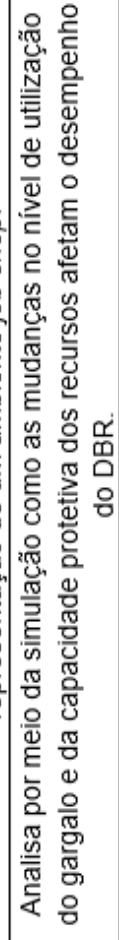 & 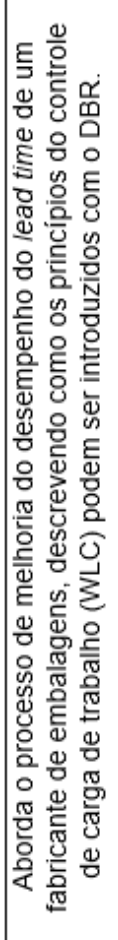 & 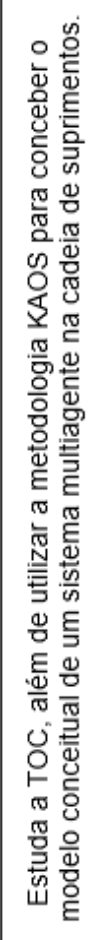 & 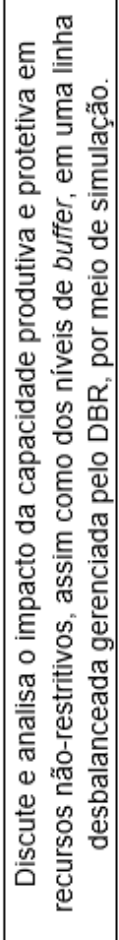 & 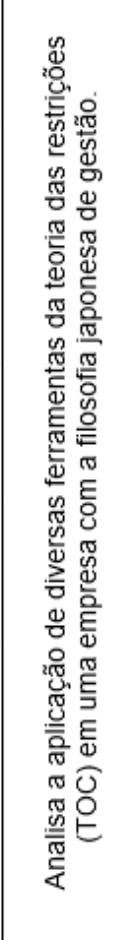 \\
\hline & 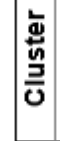 & $m$ & $r$ & n & $r$ & 6 & $r$ & ద & 우 & $\sim$ & $\sigma$ & $\infty$ & $\nabla$ \\
\hline & 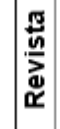 & 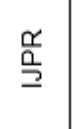 & $\begin{array}{l}\frac{\alpha}{0} \\
\underline{y}\end{array}$ & $\frac{\omega}{U}$ & $\frac{\alpha}{\underline{a}}$ & 㟧 & $\begin{array}{l}\text { 음 } \\
\frac{0}{2}\end{array}$ & $\frac{\alpha}{\underline{a}}$ & ¿̇ & $\frac{\underline{\alpha}}{\underline{\underline{O}}}$ & $\begin{array}{l}\text { S } \\
\text { జ }\end{array}$ & $\begin{array}{l}0 \\
0 \\
0\end{array}$ & 覓 \\
\hline & 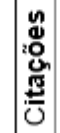 & $\stackrel{\infty}{\infty}$ & R & 8 & 8 & $\widetilde{\sim}$ & $\stackrel{\text { o̊ }}{q}$ & g) & $\stackrel{\infty}{\infty}$ & ले & ల్ల & ల్ల & ల్ల \\
\hline & 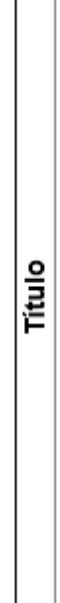 & 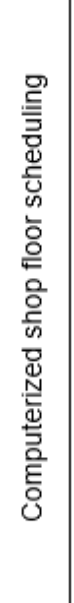 & 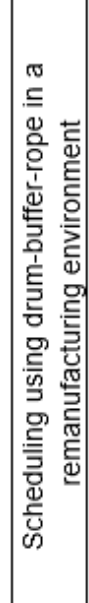 & 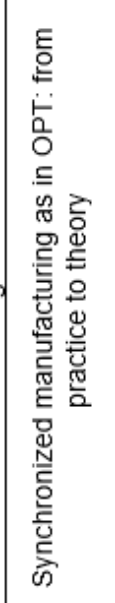 & 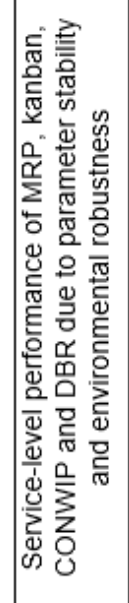 & 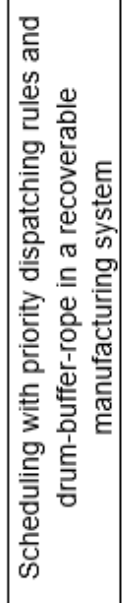 & 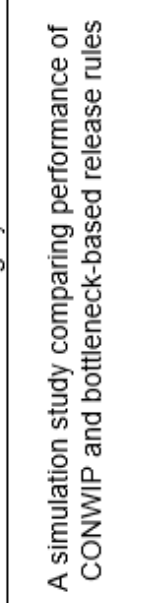 & 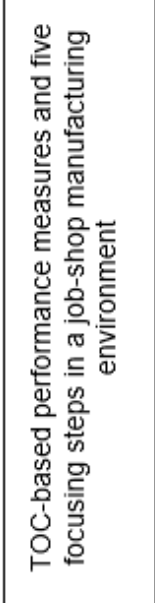 & 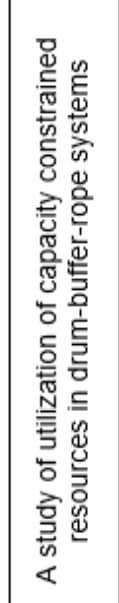 & 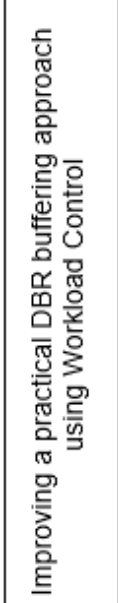 & 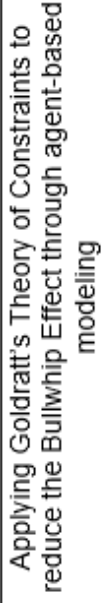 & 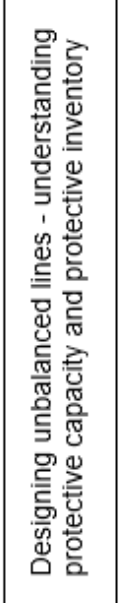 & 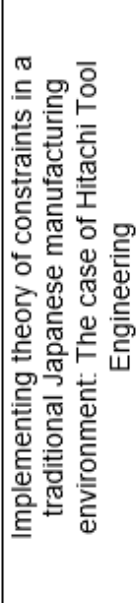 \\
\hline & 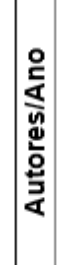 & 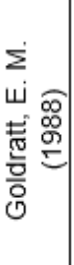 & 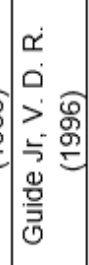 & 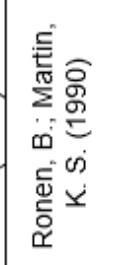 & 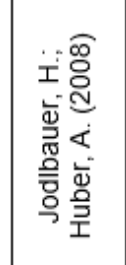 & 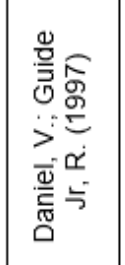 & 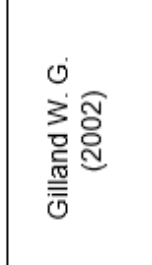 & 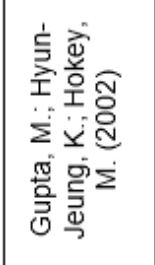 & 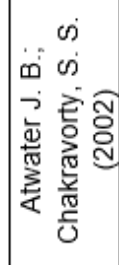 & 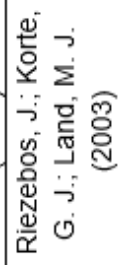 & 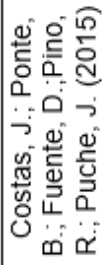 & 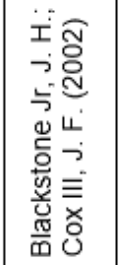 & 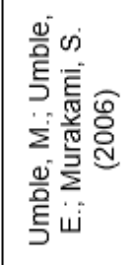 \\
\hline & 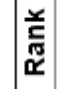 & $r$ & $N$ & $m$ & $\nabla$ & Ln & 6 & $r$ & $\infty$ & $\sigma$ & 우 & $\digamma$ & $\stackrel{\simeq}{\simeq}$ \\
\hline
\end{tabular}




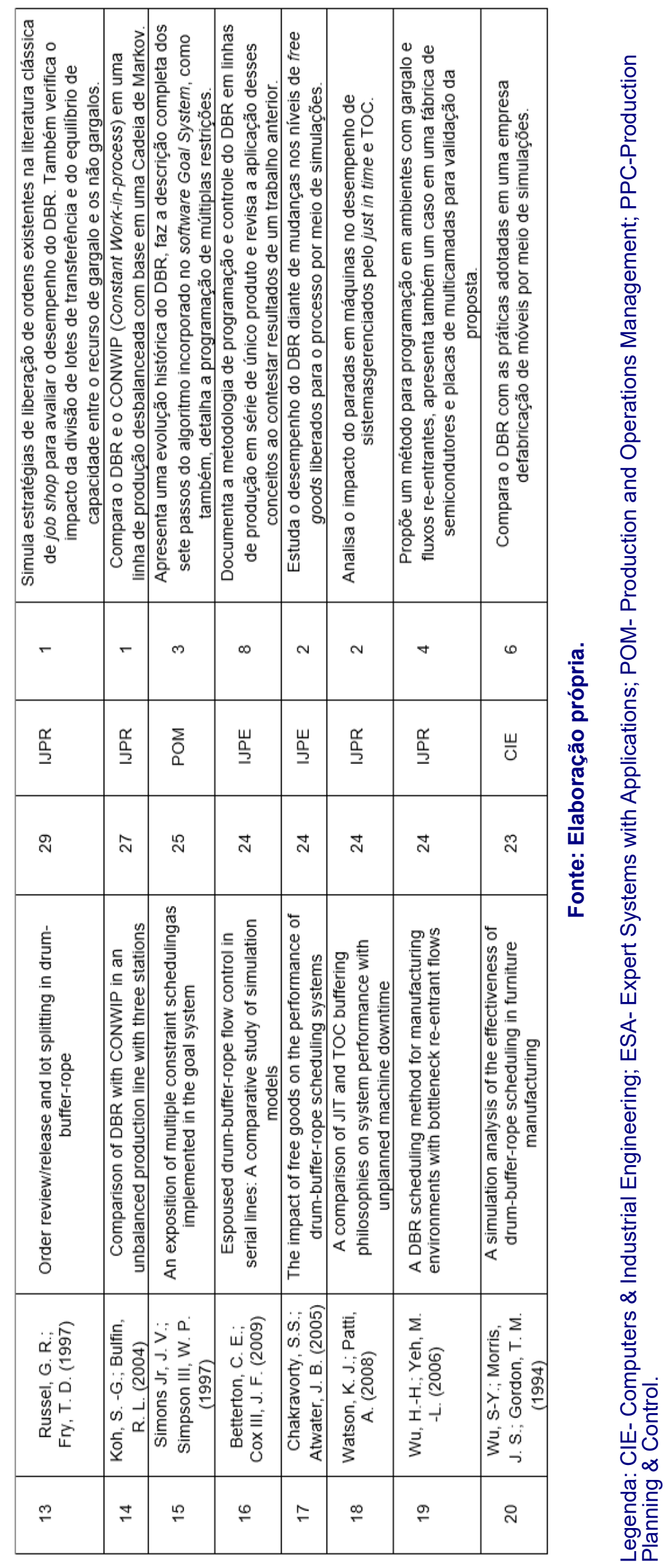




\section{Resumo}

O estudo da ciência da inovação no agronegócio se faz cada vez mais presente no Brasil e os modelos matemáticos de otimização vêm apresentando-se como ótimas ferramentas para apoio à tomada de decisão. Com o intuito de maximizar a lucratividade de uma área de cultivo de uvas e a produção de vinhos no município de Flores da Cunha, Rio Grande do Sul, desenvolveu-se um modelo matemático de programação linear (pl). o objetivo deste trabalho compreende a aplicação de conceitos e ferramentas da pl para verificar qual a variedade de uva é mais indicada na realização de um novo plantio. Foram coletados os dados relativos à situação em questão, considerando área viável de plantio, custos e restrições oriundas da produção. Desta forma, o modelo matemático foi solucionado com a utilização do método simplex. Por fim, foram avaliados os resultados, onde o maior lucro na comparação das variedades foi encontrado com a expansão do plantio de uvas Isabel, aumentando a lucratividade em $13 \%$. a otimização apresentada se mostrou eficiente para a tomada de decisão, tendo em vista que o resultado atendeu as restrições impostas do agronegócio e ao mesmo tempo maximizou a lucratividade da propriedade.

Palavras-chave: pesquisa operacional. programação linear. método simplex. maximização de lucro. uva.

\section{Alistragt}

The agribusiness innovation is increasingly present in Brazil. at the same time, mathematical models of optimization have been presenting as a tool to support decision making. In this work, aiming to maximize the profitability of a grape cultivation area and the production of wines in the municipality of Flores da Cunha, Rio Grande do Sul, a mathematical model of linear programming (pl) developed. It also seeks to evaluate the application of concepts and tools of linear programming to verify which variety of grape is most indicated in the execution of a new plant. The data collected were collected in view of the viable planting area, costs and restrictions from production. In this form, the mathematical model was solved using the simplex method. Finally, the results of the mathematical model were assessed, where the maximum profit was found by combining the types of grapes. The optimization presented has been efficient for decision-making, in view of the result meeting the constraints imposed of situation and at the same time maximizing the profitability of the property. Increasing profitability by $13 \%$.

Keywords: operations research. linear programming. simplex méthod. profit maximization. grape. 


\section{INTRODUÇÃO}

Atualmente as técnicas matemáticas têm sido cada vez mais utilizadas na área da agricultura, em busca de maior produtividade e qualidade, comenta Rajakal et al. (2019). Segundo Reifschneider et al. (2012) a história do Brasil registra os primeiros traços da agricultura desde seu descobrimento e a partir da colonização a terra foi cultivada e o país tornou-se extremamente produtivo. Anselmi (2012) apresenta um estudo que mostra que o Brasil se apresenta seguidamente em destaque na agricultura mundial.

De acordo com a análise das séries históricas disponibilizadas nas estatísticas econômicas referente a agricultura e pecuária pelo Instituto Brasileiro de Geografia e Estatística (IBGE), o número de estabelecimentos agropecuários por área apresenta crescimento contínuo nas últimas décadas. O Produto Interno Bruto (PIB) do agronegócio brasileiro cresceu 2,4\% no acumulado de janeiro e fevereiro de 2020 em relação ao ano passado nestes mesmos meses, de acordo com a Confederação da Agricultura e Pecuária no Brasil (CNA) e o Centro de Estudos Avançados em Economia Aplicada (Cepea).

Reifschneider et al. (2012) e Zhu et al. (2020) citam que houveram inúmeros avanços nas ciências aplicadas no agronegócio, permitindo aprimorar análises das plantas, dos solos, do meio ambiente, adubos e agrotóxicos, o melhoramento vegetal e animal. $\mathrm{O}$ autor também destaca que programas de inteligência artificial colaboraram nos diagnósticos de problemas relacionados a agricultura. "Ser eficiente é produzir mais com menos: menos adubo, menos água, menos mão de obra, menos área." (REIFSCHNEIDER et al., 2012, p. 95). Varas et al. (2020) apresenta que a adoção de tecnologias inovadoras que busca a maior preservação dos recursos naturais, capaz de produzir alimento em quantidade e qualidade, são fundamentais para o desenvolvimento econômico e social.

Baseados em fomentar e incrementar os estudos da ciência da inovação no agronegócio, o presente trabalho apresenta a Programação Linear $(\mathrm{PL})$ como ferramenta para o planejamento de plantio e maximização do lucro no cultivo de uvas. Hillier e Lieberman (2013) ressaltam que a PL é uma ferramenta robusta, capaz de resolver problemas complexos, focando em maximização ou minimização de resultados. Também comentam, que o método pode ser empregado na resolução de problemas com milhares de restrições e variáveis de decisão simultaneamente.

Para o presente trabalho é desenvolvida a modelagem matemática do problema de otimização de um agronegócio. O foco é dado na modelagem matemática de PL, para o planejamento de plantio e maximização do lucro no cultivo de uvas. As restrições aplicadas envolvem dimensional de área, tempo de colheita e poda das videiras, questões financeiras envolvendo custo de mão-de-obra, maquinário e insumos, bem como quesitos de mercado. Ao final, busca-se definir qual variedade de uva, ou mesmo uma combinação de variáveis, pode obter o maior lucro para o plantio de uma nova área de parreiras no município de Flores da Cunha - Rio Grande do Sul. 


\section{REFERENCIAL BIBLIOGRÁFICO}

\section{Agronegócio}

Segundo Carvalho, Santos e Carvalho (2015), por muitos anos, a agricultura familiar foi considerada somente uma agricultura de subsistência. Atualmente, sabe-se que o segmento é responsável por uma significativa parcela da produção agrícola, dos estabelecimentos rurais, da geração de empregos no campo, entre outros. É o que se comprova analisando a quantidade de pequenos produtores presentes na Serra Gaúcha. "Mesmo sob adversidades como insuficiência de terras e capital, dificuldades no financiamento, baixa disponibilidade tecnológica e fragilidade da assistência técnica, o peso da agricultura familiar para a riqueza do país é representativo" (GUILHOTO et al., 2007, p. 13). Muitas dessas famílias conseguem viver dessa exclusiva fonte de renda, gerando a necessidade da continuidade das atividades por seus descendentes.

Segundo Tan e Nasurdin (2010) e Li et al. (2020), as variáveis climáticas presentes no dia a dia da agricultura, em grande parte das vezes são incontroláveis, geram a necessidade de soluções criativas que auxiliam os produtores a quantificarem e trabalharem com as demais instabilidades de seus negócios. Trazendo assim, elevada importância tanto para o desenvolvimento dos grandes produtores como também para manutenção da agricultura familiar.

\section{Programação Linear}

Segundo Hillier e Lieberman (2013), avaliar matematicamente uma situação torna-se uma importante ferramenta para a Pesquisa Operacional (PO), prevendo processos, operações e esboçando sistemas com o intuito de reduzir riscos e maximizar ganhos. Corroborando temos o estudo de Taha (2007), que afirma também, que a modelagem matemática ajuda a resolver problemas operacionais utilizando diversas técnicas. Como exemplo, o método Simplex, que em 1947 foi apresentado e desde então revolucionou a otimização em diversas áreas. Dentre elas a agricultura, tema da pesquisa em questão.

Bruniera (2018), comenta que o método Simplex contempla uma função objetivo (de maximização ou minimização) com a possibilidade de considerar diversas restrições em forma de equações e inequações lineares. A solução dessas questões matemáticas tem o intuito de encontrar o ponto ótimo ao qual diferentes organizações poderão maximizar lucros ou minimizar custos de operação. Com a aplicação do método, a própria autora propôs uma otimização no transporte de produtos em uma micro cervejeira do interior de São Paulo, resultando num acréscimo de $5 \%$ no lucro da operação. Enquanto que Vergara et al. (2015), usou o mesmo modelo propondo uma minimização dos custos de produção de uma vidraçaria localizada em Belém do Pará. A técnica desencadearia uma redução de $7 \%$ nos custos, caso a empresa adotasse a gestão humana com horas extras e subcontratadas.

O método Simplex, base matemática utilizada para desenvolvimento de vários recursos computacionais de otimização, também está presente no Solver, suplemento do Microsoft Excel®, segundo Lachtermacher (2009) é um dos mais usados em otimizações, levando em consideração a popularidade do desenvolvedor e também foi ferramenta do 
presente trabalho.

De uma forma geral, modelos de PL podem ser representados por meio de uma função objetivo (maximização ou minimização) e de um conjunto de restrições. Nas equações a seguir apresenta-se um modelo geral descrito por Hillier e Lieberman (2013),

$$
\operatorname{Max} / \operatorname{Min} f(\boldsymbol{x})=c_{1} x_{1}+c_{2} x_{2}+\cdots+c_{n} x_{n}
$$

Sujeito a:

$$
\begin{gathered}
a_{11} x_{1}+a_{12} x_{2}+\cdots+a_{1 n} x_{n}\{=, \leq, \geq\} b_{1} \\
a_{21} x_{1}+a_{22} x_{2}+\cdots+a_{2 n} x_{n}\{=, \leq, \geq\} b_{2} \\
a_{m 1} x_{1}+a_{m 2} x_{2}+\cdots+a_{m n} x_{n}\{=, \leq, \geq\} b_{m} \\
x_{1} \geq 0, x_{2} \geq 0, \ldots, x_{n} \geq 0
\end{gathered}
$$

Onde:

- $\operatorname{Max} / \operatorname{Min} f(\boldsymbol{x})$ é a função matemática a ser maximizada ou minimizada;

- $x_{1}, x_{2}, \ldots, x_{n}$, são as variáveis do modelo;

- $c_{1}, c_{2}, \ldots, c_{n}$, são os coeficientes das variáveis na função objetivo;

- $a_{i j}$ e $b_{j}$ são os coeficientes das variáveis nas restrições, dos limites a serem considerados.

\section{METODOLOGIA DA PESQUISA}

O estudo foi realizado no município de Flores da Cunha, na região da Serra Gaúcha do Estado do Rio Grande do Sul. O município é um dos maiores produtores de uvas e vinhos do país, conforme informações do Cadastro Vinícola do RS Ibravin, em que a produção local chegou a 101 milhões de quilos de uva e 120 milhões de litros de vinho em 2017/2018. São considerados 5 mil hectares destinados ao plantio de uvas, sendo em média R\$ 29.511 o rendimento médio por hectare, segundo dados disponibilizados pelo SEBRAE, no levantamento do Perfil das Cidades Gaúchas em 2019.

No município se considerou uma propriedade com 8 hectares de área agricultável, e mais 1 hectare preparado para novo plantio. Foram levantados os dados a respeito do plantio, da colheita, da poda, custos, lucro, entre outros, como finalidade a elaboração das restrições. Sendo elaborado um modelo que segue as premissas para resolução da PL, o qual contém uma função objetivo e será aplicada a maximização de lucro.

O fluxograma apresentado na Figura 1 ilustra os passos adotados para execução da presente análise. 
Figura 1 - Fluxograma das etapas utilizadas no desenvolvimento da análise

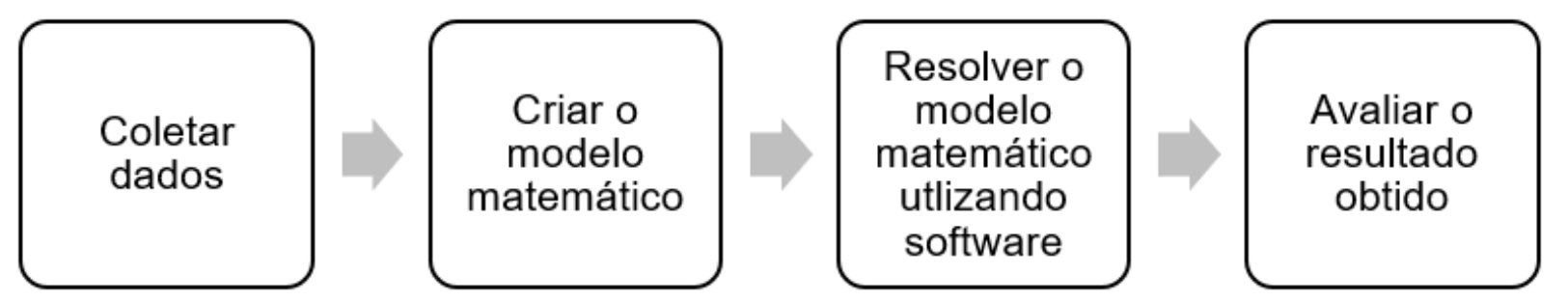

Para o levantamento de dados foi entrevistado o vitivinicultor responsável pela propriedade, baseado nos dados obtidos na última safra, em que são apresentados na Tabela 1.

Tabela 1 - Dados da propriedade rural

\begin{tabular}{cccccc}
\hline Variedade de uva & Area (ha) & R\$/kg & kg/hectare & R\$/Hectare (Custo) & R\$/Hectare (Lucro) \\
\hline Uva Bordo & 4,5 & 1,30 & 30000 & 27300 & 11700 \\
Uva Niagra Branca & 2,5 & 1,10 & 35000 & 26950 & 11550 \\
Uva Isabel & 0,5 & 1,07 & 40000 & 29960 & 12840 \\
Uva Coder 13 & 0,5 & 0,92 & 37000 & 23828 & 10212 \\
\hline
\end{tabular}

Fonte: Dados da propriedade rural da safra de 2020

Na primeira coluna, nomeada "Variedade de uva" estão relacionadas a quatro variedades cultivadas na propriedade. Na segunda, são apresentadas a quantidade de área em hectares plantadas para cada variedade atualmente na propriedade. Os valores em reais por quilo estão na terceira coluna. Na quarta coluna, é apresentado a média de produção em quilos por hectare. Na quinta coluna é apresentado custo por hectare para produção, dentre estes custos estão somados valores na utilização de maquinário, mão-de-obra e insumos para produção, como adubos e fertilizantes. Na última coluna apresenta-se o lucro líquido por hectare para cada variedade.

Para elaboração das restrições de atendimento à demanda já existente, uma análise técnica de um vitivinicultor orientou que para a variedade de uva Bordô sejam cultivados mais do que 3 hectares, devido à alta procura no mercado. Caso semelhante para o plantio de Isabel, que pode contar com no mínimo 2 hectares. Para a variedade de uva Niagra Branca no mínimo 1,5 hectares, por serem uvas de média procura. Para a variedade Coder 13 no mínimo 0,5 hectare, por se tratar também de uma uva de baixa demanda e por amadurecer muito tarde. Inclusive, são necessárias as quantidades mínimas apresentadas, devido aos períodos de colheita e poda, em que ocorrem um após o outro de acordo com a maturação.

Por fim, os dados levantados serão aplicados no modelo matemático, para posterior aplicação na ferramenta computacional selecionada para o presente trabalho. O objetivo é de avaliar qual a combinação de variedades de uvas é mais lucrativa e assim orientar o vitivinicultor no plantio no próximo cultivo. 


\section{DESCRIÇÃO E ANÁLISE DOS RESULTADOS}

Neste tópico são elaboradas as funções e restrições do modelo matemático. Os mesmos são definidos a partir dos dados coletados. Por fim, são apresentados os resultados.

\section{Função objetivo}

A função objetivo a seguir foi definida, visando uma maximização global do lucro. Desta forma, se consideram os lucros para cada variedade de uva cultivada na propriedade, de acordo com os dados informados na Tabela 1. A função é definida como:

$$
\text { Max } L=11700 A U B+11550 A U N+12840 A U I+10212 \text { AUC }
$$

Em que:

$L=$ Função objetivo = Lucro $(R \$)$;

AUB = Área de uva Bordô;

$\mathrm{AUN}=$ Área de uva Niagra Branca;

$\mathrm{AUI}=$ Área de uva Isabel;

AUC = Área de uva Coder 13.

\section{Restrições do modelo}

A seguir são detalhadas as restrições que serão aplicadas.

\section{a) Restrições de terras:}

A área agricultável da propriedade são 9 hectares, sendo 1 hectare disponível para novo plantio. Dessa forma para fins de cálculo serão utilizados 9 hectares como área máxima a ser utilizada. Sendo assim:

$$
A U B+A U N+A U I+A U C \leq 9
$$

Considerando a orientação dada pelo vitivinicultor apresentada no tópico anterior, que representam a quantidade de área mínima a ser cultivada para cada variedade de uva, seguem restrições estruturadas:

AUB $\geq 3$

AUN $\geq 1,5$

$\mathrm{AUI} \geq 2$

AUC $\geq 0,5$

b) Restrições financeiras:

As restrições financeiras apresentam o somatório dos custos para produção por 
hectare. São considerados mão de obra, maquinário e insumos para produção. Por exemplo, o custo total da área de uva Bordô é $\mathrm{R} \$ 27.300,00$. A partir disso obtém-se o seguinte:

$$
27300 \mathrm{AUB}+26950 \mathrm{AUN}+29960 \mathrm{AUI}+23828 \mathrm{AUC} \leq 250000
$$

\section{c) Restrições tempo de colheita:}

Estas restrições regram a quantidade máxima de dias de colheita por hectare que a mesma pode ocorrer. Isto porque o tempo de maturação da uva deve ser avaliado no momento da colheita e a mesma não pode exceder 20 dias. Por exemplo, o limite de dias para a colheita de 1 hectare de uva Bordô, são 2 dias. A restrição para esta condição fica da seguinte forma:

$$
2 \mathrm{AUB}+3 \mathrm{AUN}+2 \mathrm{AUI}+2,5 \mathrm{AUC} \leq 20
$$

\section{d) Restrições tempo de poda:}

Semelhante às restrições de tempo de colheita, estas restrições, por sua vez, regram a quantidade de dias de poda por hectare que devem ocorrer no máximo. Devido ao início da brotação, a poda não deve exceder 28 dias. Como exemplo, são 3,2 dias no máximo, por hectare, para a poda das parreiras de variedade Bordô:

$$
3,2 \mathrm{AUB}+2,8 \mathrm{AUN}+3 \mathrm{AUI}+2,5 \mathrm{AUC} \leq 28
$$

\section{Resolução do modelo}

Por fim, o modelo matemático apresentado foi implementado em formato de planiIha. Assim, foi possível utilizar o Solver do software Microsoft Excel ${ }^{\circledR}$ referente a otimização, onde se utilizou o método Simplex para solução. Os valores obtidos foram comparados com os valores praticados nos cultivos da propriedade (ver Tabela 2).

Tabela 2 - Comparação dos resultados entre a situação atual e a otimizada

\begin{tabular}{lcccc}
\hline & \multicolumn{2}{c}{ Antes } & \multicolumn{2}{c}{ Depois } \\
\hline Variedade de uva & Hectares & Lucro (R\$) & Hectares & Lucro (R\$) \\
\hline Uva Bordô & 4,5 & 52650 & 3 & 35100 \\
Uva Niagra Branca & 2,5 & 28875 & 1,5 & 17325 \\
Uva Isabel & 0,5 & 6420 & 3,86 & 49612 \\
Uva Coder 13 & 0,5 & 5106 & 0,5 & 5106 \\
\hline Total & 8 & 93051 & 8,86 & 107143 \\
\hline
\end{tabular}

Fonte: Dados da propriedade rural da safra de 2020 e dados obtidos após aplicação do modelo matemático

Analisando os dados, observa-se que há uma alteração na quantidade de área para as três primeiras variedades de uva, mantendo-se a mesma para a última. De acordo com os resultados da otimização, os maiores valores de lucro por variedade a serem obtidos com o plantio são: em primeiro com a uva Isabel, em segundo da uva Bordô, em 
terceiro da uva Niagra Branca e por último da uva Coder 13. Com a aplicação de plantio das variedades, nos respectivos hectares recomendados, se obterá um aumento de $\mathrm{R} \$$ $14.092,00$ no lucro.

\section{CONSIDERAÇÕES FINAIS}

Por meio da análise realizada, verificou-se que a aplicação de um modelo matemático de programação linear é capaz de definir qual a combinação do plantio de uva garante maior lucro. O método Simplex foi efetivo em considerar todas as restrições aplicadas e apresentar um resultado satisfatório com o que o vitivinicultor julga ser importante. Tal aplicação, contribui para que a tomada de decisão seja ainda mais assertiva. Sem o modelo matemático a análise é feita de forma intuitiva pelo dono da propriedade. A programação linear neste caso, indica a quantidade ótima de área a ser cultivada para se obter a máxima lucratividade.

Pelo fato da variedade de uva Isabel, ser considerada mais lucrativa e obter a maior diferença de hectares, comparando-se o cenário atual da propriedade com o calculado, recomenda-se que o vitivinicultor opte pelo plantio da mesma. Sendo que também é recomendado, que dentro do possível ocorra a troca das variedades, isto é, o plantio no número de hectares sugerido pela programação linear. Por fim, com plantio de acordo com o proposto pelo modelo matemático, a propriedade tem um aumento de $13 \%$ no lucro. Como limitação do modelo apresentado, tem-se que os valores de lucro unitário por hectare de uva cultivada são fixos, entretanto, os mesmos podem variar de um ano para outro. Desta forma, como sugestão para trabalhos futuros, recomenda-se a integração de modelos de previsão, de forma a buscar uma solução com maior confiabilidade.

\section{REFERÊNCIAS}

ANSELMI, A. A. Adoção da agricultura de precisão no Rio Grande do Sul. Porto Alegre: UFRGS: Centro de Estudos e Pesquisa em Agronegócio, 2012. 104 p.

BRUNIERA, B. Otimização linear e aplicação no problema de transporte e designação de tarefas. 66 f. TCC (Graduação) - Curso de Licenciatura em Matemática, Universidade Tecnológica Federal do Paraná, Cornélio Procópio, 2018.

CARVALHO, C. O.; SANTOS, A. C.; CARVALHO, G. R. Rede Brasil Rural: inovação no contexto da agricultura familiar. Revista em Agronegócio e Meio Ambiente, v. 8, n. 1, p. 79-94, 15 abr. 2015. Centro Universitário de Maringa.

CNA Brasil. PIB do agronegócio cresce 2,42\% no primeiro bimestre de 2020. Disponível em: $<$ https://www.cnabrasil.org.br/noticias/pib-do-agronegocio-cresce-2-42-no-primeiro-bimestrede-2020\#: :text=Bras\%C3\%ADlia\%20(12\%2F05\%2F2020,em\%20Economia\%20Aplicada\%20 (Cepea)>. Acesso em: 28 jun. 2020.

GUILHOTO, J. J. M.; ICHIHARA, S. M.; SILVEIRA, F. G.; DINIZ, B. P. C.; AZZONI, C. R.; MOREIRA, G. R. C. A importância da agricultura familiar no Brasil e em seus estados. In: ENCONTRO NACIONAL DE ECONOMIA, 35., 2007, Recife. Artigo. [s.i]: Anpec, 2007. p. 1-18. Disponível em: <http://www.anpec.org.br/encontro2007/artigos/A07A089.pdf>. Acesso em: 22 jun. 2020.

HILLIER, F. S.; LIEBERMAN, G. J. Introdução à pesquisa operacional. 9. ed. [s.i]: Mc Graw Hill, 2013. Cap. 20. p. 1-72. 
Instituto Brasileiro de Geografia e Estatística (IBGE). Séries históricas. Disponível em: <https:// www.ibge.gov.br/estatisticas/economicas/agricultura-e-pecuaria/21814-2017-censo-agropecuario. html?=\&t=series-historicas>. Acesso em: 28 jun. 2020.

Instituto Brasileiro do Vinho (IBRAVIN). Dados estatísticos. Disponível em: <https://www.ibravin. org.br/>. Acesso em: 28 jun. 2020.

LACHTERMACHER, G. Pesquisa operacional na tomada de decisões. [S.I.]: Person Prentice Hall, 2009.

LI, X.; LIU, H.; LI, J.; HE, X.; GONG, P.; LIN, E.; LI, K.; LI, L.; BINLEY, A. Experimental study and multi-objective optimization for drip irrigation of grapes in arid areas of northwest. Agricultural Water Management, v. 232, p. 1-13, jan. 2020.

RAJAKAL, J. P.; NG, D. K. S.; TAN, R. R.; ANDIAPPAN, V.; WAN, Y. K. A mathematical optimisation model for analysis of minimal cropland expansion in agro value chains. Sustainable Production and Consumption, v. 20, p. 178-191, jun. 2019.

REIFSCHNEIDER, F. J. B.; HENZ, G. P.; RAGASSI, C. F.; ANJOS, U. G.; FERRAZ, R. M. Novos ângulos da história da agricultura no Brasil - 2 ed. - Brasília, DF: Embrapa, 2012.

SEBRAE. Perfil das Cidades Gaúchas - Flores da Cunha. Disponível em: <https://datasebrae. com.br/municipios/rs/Perfil_Cidades_Gauchas-Flores_da_Cunha.pdf>. Acesso em: 28 jun. 2020.

TAHA, H. A. Pesquisa operacional. 8. ed. São Paulo: Person, 2007. 366 p.

TAN, C. L.; NASURDIN, A. M. Human resource management practices and organizational innovation: an empirical study in Malaysia. Journal of Applied Business Research, v. 26, n. 4, p. 105-116, 2010.

VARAS, M.; BASSO, F.; MATURANA, S.; OSORIO, D.; PEZOA, R. A multi-objective approach for supporting wine grape harvest operations. Computers \& Industrial Engineering, v. 145, p. 1-15, mai. 2020.

VERGARA, B. M.; ANDRADE, G. S.; OLIVEIRA, K. J. J.; SANTOS, R. S.; SANTOS, Y. B. I. Aplicação da programação linear para minimização de custos no processo produtivo de uma vidraçaria. In: ENCONTRO NACIONAL DE ENGENHARIA DE PRODUCAO, 35., 2015, Fortaleza. Artigo. [s.i]: Abepro, 2015. p. 1-14. Disponível em: <http://www.abepro.org.br/biblioteca/TN STP_211_250_27445.pdf>. Acesso em: 20 jun. 2020.

ZHU, J.; FRAYSSE, R.; TROUGHT, M. C. T.; RAW, V.; YANG, L.; GREVEN, M.; DAMIAN, M.; AGNEW, R. Quantifying the seasonal variations in grapevine yield components based on pre- and post-flowering weather conditions. OENO One 2020, v. 54, n. 2, p. 159-168, abr. 2020. 


\section{Eeonomia cireular e inovakzão aherta nos anais do SIMPEP (2010-2019)}

\section{Gircular economy and open innovation in SIMPEP'S annals (2010-2019)}

Claudia Maria Napolitano Sanchez Morasco Universidade de Araraquara - UNIARA

Vera Mariza Henriques de Miranda Costa Universidade de Araraquara - UNIARA

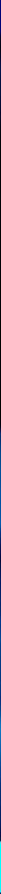




\section{Resumo}

As medidas de contenção e combate à pandemia impactaram diretamente a vida de pessoas e empresas. Neste cenário de incertezas e retração econômica, organizações públicas e privadas de diversos setores, perceberam que os desafios a serem enfrentados eram muito mais complexos que suas previsões necessitando unir pesquisas internas e externas, na busca por soluções, colocando em prática a Inovação Aberta (IA). A conscientização de que o desenvolvimento econômico pode ser realizado sem a degradação do meio ambiente motiva a inclusão, em cada prática inovadora, dos conceitos da Economia Circular (EC) para que o capital natural não seja colocado em risco em nome da recuperação da economia. Este estudo se propõe a contribuir com a formação de um panorama de toda produção científica com conteúdos relacionados a inovação aberta e a economia circular do SIMPEP, de 2010 à 2019, através de uma revisão sistemática de literatura. Da análise dos artigos verificou-se que ambos os temas, IA e EC, são viáveis, podem gerar novos modelos de negócios, da pluralidade de aplicações pode contribuir para que as empresas mantenham sua competitividade e permaneçam no mercado.

Palavras-chave: inovação aberta. economia circular. anais SIMPEP. revisão sistemática da literatura.

\section{Alistract}

The measures to contain and combat the pandemic directly impacted the lives of people and companies. In this scenario of uncertainties and economic downturn, public and private organizations from different sectors, realized that the challenges to be faced were much more complex than their predictions, needing to unite internal and external research, in the search for solutions, putting Open Innovation (OI) into practice. The awareness that economic development can be achieved without degrading the environment motivates the inclusion, in each innovative practice, of the concepts of the Circular Economy (CE) so that natural capital is not put at risk in the name of economic recovery. This study aims to contribute to the formation of an overview of all scientific production with content related to SIMPEP's open innovation and circular economy, from 2010 to 2019 , through a systematic literature review. From the analysis of the articles, it was found that both themes, $\mathrm{OI}$ and $\mathrm{CE}$, are viable, can generate new business models, from the plurality of applications can contribute for companies to maintain their competitiveness and remain in the market.

Keywords: open innovation. circular economy. SIMPEP's annals. systematic literature review. 


\section{INTRODUÇÃO}

Planejar ações que irão nortear os rumos das organizações é uma das principais tarefas a executar, pois gerencia os recursos de uma empresa (SLACK, 2009) e, caso alguma fase seja negligenciada, a competitividade pode ser perdida (PORTER, 1989).

Ao iniciarem o ano de 2020 as organizações produziam conforme seus planos, formais ou informais, embasados em seus dados e orientados para a manutenção de sua competitividade.

Em março, pouco menos de três meses do início deste ano, a Organização Mundial da Saúde (OMS) reconheceu a COVID-19 como pandemia. Devido ao rápido contágio e à gravidade da doença, governos foram obrigados a adotar severas medidas de isolamento social, como única ação capaz de conter a contaminação em massa da população e evitar danos maiores.

As medidas de isolamento impactaram diretamente a vida de pessoas e organizações, pois trouxeram à população fatores de estresse, não apenas pela própria pandemia, mas também em decorrência das políticas que visam minimizar seus danos (MORAES, 2020). A combinação das medidas de isolamento, o medo do contágio e o cenário de incertezas, provocou uma grande retração da atividade econômica (OECD, 2020). Segundo Chesbrough (2020), em todo o globo, a COVID-19 está testando severamente os sistemas de saúde e, em breve, todo o sistema econômico do planeta será colocado à prova.

Nesse cenário, organizações públicas e privadas perceberam que os desafios a serem enfrentados eram muito mais complexos que suas previsões e necessitavam, não apenas das informações e pesquisas internas, mas também de toda informação e pesquisas que estivessem disponíveis além de suas fronteiras.

É a partir dessa percepção que cabe retomar o conceito de inovação aberta (IA), através de cujas estratégias as empresas ampliam suas fronteiras e permitem a entrada de ideias externas que irão auxiliar no desenvolvimento de suas atividades, ampliando a capacidade de inovação das organizações (CHESBROUGH, 2003). Saunila (2016) afirma que esta capacidade é determinante para as organizações, por melhorar seu desempenho e ser fonte de vantagem competitiva. Chesbrough (2020) aponta a presença da IA em inúmeras ações utilizadas no combate à pandemia: compartilhamento de pesquisas, ações e resultados de sucesso, na saúde e em outras áreas e afirma que a inovação aberta abre possibilidades para a recuperação da economia.

Essa evidência requer atenção para os meios que, em nome da recuperação da economia, sejam deixados de lado outros aspectos, como os sociais e os ambientais. Se a IA se apresenta como a força motriz da recuperação econômica, é importante que sejam levados em consideração os pilares que sustentam a Economia Circular (EC), evitando que a recuperação esgote, de forma irrecuperável, os recursos naturais ou os subordine a soluções econômicas imediatistas, que podem levar à deterioração de recursos disponíveis e ao aprofundamento de desigualdades.

A integração do desenvolvimento econômico com respeito ao meio ambiente, tendo a inovação como veículo é, segundo Kanger e Schot (2018), um caminho delicado que 
exige a união de várias dimensões da sociedade, sem esquecer de que, sob o ponto de vista da empresa, trata-se de sua produção e de seu produto, que pode ser inovador e circular.

A indicação do tema do XXVII SIMPEP: "Economia Circular e suas interfaces com a Engenharia de Produção" constituiu um elemento motivador para a investigação nesse campo. Assim, decidiu-se unir IA e EC, através de uma Revisão Bibliográfica Sistemática (RBS) dos Anais do Simpósio de Engenharia de Produção (SIMPEP), 2010-2019, com o intuito de disponibilizar o que já foi produzido neste importante evento, que reúne organizações públicas e privadas de todo o Brasil e que pode estimular investigações junto a empresas que têm a intenção de manter sua competitividade e permanecer no mercado, na busca por minorar os efeitos negativos da pandemia.

Foi a seguinte a questão norteadora da RBS: "Quais os focos, a evolução no período 2010-2019, a distribuição por áreas/sub-áreas temáticas do SIMPEP, a origem dos autores e a contribuição dos artigos sobre IA e EC, presentes nos Anais do SIMPEP para a orientação de procedimentos de pesquisadores e empresas diante dos efeitos da Covid 19 ?"

\section{INOVAÇÃO ABERTA (IA) E ECONOMIA CIRCULAR (EC)}

IA e EC sempre foram vistas como duas áreas distintas, mas Cunico et al. (2017) mostram a relação entre IA, sustentabilidade e meio ambiente. A integração de inovação tecnológica com a EC é defendida por Jabbour et al. (2017) e Ferrari, Scaliza e Jugend (2019) identificam a preocupação em desenvolver tecnologias voltadas à EC e compartiIha-las, como uma tendência.

Sob o ponto de vista da empresa, trata-se de sua produção e seu produto, e ambos podem ser inovadores e circulares.

Por muito tempo a inovação foi o resultado das pesquisas realizadas em "ambiente" de laboratório (P\&D), dentro das organizações que tinham recursos para mantê-los, sendo este o modelo de Inovação Fechada (CHESBROUGH, 2003).

Mudanças no mercado fizeram com que organizações permitissem a pesquisadores externos que participassem de seus processos internos, contribuindo com novas ideias que seriam transformadas, dentro da empresa, em produtos ou serviços, constituindo-se, assim, o modelo de IA, definido por Chesbrough (2003).

AIA pode ser classificada, da perspectiva da empresa, segundo Chesbrough (2006), em três dimensões: 1 . de dentro para fora, quando comercializa seus produtos para empresas com modelo de negócio mais adequado ao produto; 2 . de fora para dentro, quando utiliza conhecimento gerado externamente, para inovar internamente; e 3. cocriação, quando forma aliança com outros atores para desenvolver e comercializar inovações.

A economia mundial é baseada em um modelo unidirecional de produção, sistema tradicional, no qual os recursos da natureza são extraídos, beneficiados, comercializados, utilizados e descartados tornando-se um problema para a sociedade (EMF, 2017).

O modelo linear é definido como extração, fabricação, uso e descarte e tem gerado 
preocupação mundial, decorrente dos impactos socioambientais que tem gerado.

A EC é uma alternativa ao modelo linear e busca redefinir a noção de crescimento econômico, mudando da economia do desperdício para a economia regenerativa e restauradora, dissociando a atividade econômica do consumo de recursos finitos (EMF, 2017). Assim, a EC é considerada como uma solução para o desenvolvimento sustentável, isto é, o crescimento econômico desvinculado da degradação do meio ambiente, mesmo exigindo sérias mudanças nos modos de produzir e consumir (FIORINI, 2019).

O modelo circular constrói capital econômico, natural e social e se baseia em três princípios: eliminar resíduos e poluição desde o princípio; manter produtos e materiais em uso e regenerar sistemas naturais. (EMF, 2017).

\section{METODOLOGIA}

A pesquisa que deu suporte ao presente artigo se enquadra, nos termos de Berto e Nakano (2014), como descritiva, qualitativa, longitudinal e teórico-conceitual. Primeiramente, foram buscados conceitos sobre IA e EC, nas bases Scielo, Google Acadêmico e Science Direct, por meio de, nos termos de Rother (2007), Revisão Narrativa.

O levantamento dos artigos nos Anais do SIMPEP (2010-2019) foi conduzido utilizando a Revisão Sistemática da Literatura (RSL) ou Revisão Bibliográfica Sistemática (RBS), que têm por objetivo, valendo-se de procedimentos metódicos, a seleção e análise crítica de determinado assunto, em bases e períodos pré-determinados (CONFORTO; AMARAL; SILVA, 2011; ROTHER, 2007).

O levantamento foi feito em todas as áreas temáticas da Engenharia de Produção (EP), utilizando as palavras "inovação aberta" e "economia circular" nos campos palavra-chave, título e resumo.

A partir da questão da pesquisa proposta, foram feitas as exclusões dos arquivos que, destacando os termos "inovação aberta" ou "economia circular", não tinham por foco principal essas temáticas. Após as exclusões dos arquivos duplicados e dos artigos que usavam "inovação aberta" e "economia circular" fora da delimitação estabelecida, foram identificados 14 artigos sobre IA e 12 sobre EC.

Os resultados estão apresentados em dois quadros, reunindo artigos sobre IA e sobre EC, abrangendo, cada um deles, ano de publicação, objetivos e aportes teóricos, área e subárea da EP do SIMPEP em que se enquadram, distribuição dos autores por estados, sendo ainda realizada a apresentação da contribuição dos artigos levantados para as respectivas áreas de investigação.

\section{RESULTADOS: IA E EC NOS ANAIS DO SIMPEP (2009-2019)}

Conforme o apresentado no Quadro 1, foi baixa (14), mas constante, variando de 1 a 2 por ano, a publicação de artigos sobre IA no período de 2009 a 2019 e não houve publicação em 2013. 
Quadro 1 - Artigos com conteúdo de Inovação Aberta nos Anais do SIMPEP (2010-2019)

\begin{tabular}{|c|c|c|c|c|}
\hline Ano & Autores & Objetivos & $\begin{array}{l}\text { Principais } \\
\text { Aportes }\end{array}$ & $\begin{array}{c}\text { Áreas } \\
\text { Sub áreas }\end{array}$ \\
\hline $\begin{array}{c}2010 \\
(1)\end{array}$ & $\begin{array}{l}\text { Magnano, P. F.; } \\
\text { Fettermann, D. C.; } \\
\text { Echeveste, M. } \\
\text { E. S. }\end{array}$ & $\begin{array}{c}\text { Apresentar a Batalha de Conceitos, } \\
\text { uma das ferramentas da IA, para que } \\
\text { jovens estudantes gerem soluções } \\
\text { criativas de problemas. }\end{array}$ & Barifouse & $\begin{array}{l}8 \\
\text { 8.1 Gestão } \\
\text { da Inovação }\end{array}$ \\
\hline \multirow[b]{2}{*}{$\begin{array}{c}2011 \\
(2)\end{array}$} & $\begin{array}{l}\text { Rocha, E. A. M.; } \\
\text { Anjos, F. E. V.; } \\
\text { Domingues, J.; } \\
\text { Silva, M. G. }\end{array}$ & $\begin{array}{l}\text { Contribuir para o entendimento das } \\
\text { relações entre os processos de cocria- } \\
\text { ção e a estratégia de produção. }\end{array}$ & Ramaswamy & $\begin{array}{l}7 \\
7.2 \text { Estra- } \\
\text { tégia de } \\
\text { Produção }\end{array}$ \\
\hline & $\begin{array}{l}\text { Lima, E. B.; } \\
\text { Cohen, M. F.; } \\
\text { Rebouças, W. F. }\end{array}$ & $\begin{array}{l}\text { Conceituar inovação aberta e fecha- } \\
\text { da; identificar características gerais } \\
\text { pertinentes ao comportamento inova- } \\
\text { dor aberto nas organizações; elencar } \\
\text { variáveis de pesquisa que permitam } \\
\text { identificar a aderência de práticas } \\
\text { organizacionais ao conceito de IA. }\end{array}$ & $\begin{array}{l}\text { Chesbrough; } \\
\text { Schwartz; Vanha- } \\
\text { verbeke }\end{array}$ & $\begin{array}{l}8 \\
\text { 8.1 Gestão } \\
\text { da Inovação }\end{array}$ \\
\hline $\begin{array}{c}2012 \\
(1)\end{array}$ & $\begin{array}{l}\text { Scherer, J. O.; } \\
\text { Ribeiro, J. L. D }\end{array}$ & $\begin{array}{c}\text { Contribuir para a gestão de projetos de } \\
\text { IA, identificando características impor- } \\
\text { tantes para o sucesso de um programa } \\
\text { de IA, utilizando a internet. }\end{array}$ & $\begin{array}{l}\text { Chesbrough; Hu- } \\
\text { sig; Kohn }\end{array}$ & $\begin{array}{l}8 \\
\text { 8.1 Gestão } \\
\text { da Inovação }\end{array}$ \\
\hline \multirow{2}{*}{$\begin{array}{c}2014 \\
(2)\end{array}$} & $\begin{array}{l}\text { Komesu, a. H.; } \\
\text { Nascimento, C. } \\
\text { M.; } \\
\text { Ribeiro Junior,H. } \\
\text { J.; } \\
\text { Figueiredo, V. G. } \\
\text { C. }\end{array}$ & $\begin{array}{c}\text { Explicitar a importância do conheci- } \\
\text { mento aliado com a inovação e eluci- } \\
\text { dar sobre as potencialidades derivadas } \\
\text { do uso de práticas que podem promo- } \\
\text { ver um diferencial competitivo para a } \\
\text { empresa e seu crescimento no cenário } \\
\text { mundial. }\end{array}$ & $\begin{array}{l}\text { Chesbrough; Fu; } \\
\text { Wallin; Krogh }\end{array}$ & $\begin{array}{l}8 \\
\text { 8.1 Gestão } \\
\text { da Inovação }\end{array}$ \\
\hline & $\begin{array}{l}\text { Scaliza, J. A. A.; } \\
\text { Jugend, D. }\end{array}$ & $\begin{array}{c}\text { Identificar algumas práticas de IA e } \\
\text { apresentar estudos sobre cada uma } \\
\text { delas. }\end{array}$ & Chesbrough; & $\begin{array}{l}7 \\
\text { 7.5 Redes } \\
\text { de Empr. } \\
\text { e Gest. } \\
\text { da Cadeia } \\
\text { Prod. } \\
\end{array}$ \\
\hline \multirow{2}{*}{$\begin{array}{c}2015 \\
(2)\end{array}$} & $\begin{array}{l}\text { Cruz, N. J. T.; } \\
\text { Lezana, A. G. R.; } \\
\text { Santos, P. C. F.; } \\
\text { Zancan, C.; Dan- } \\
\quad \text { tas, A. B. }\end{array}$ & $\begin{array}{l}\text { Identificar os possíveis riscos advindos } \\
\text { da IA na opinião de empreendedores, } \\
\text { bem como os mecanismos que pos- } \\
\text { sam vir a ajudar a gerir esses riscos. }\end{array}$ & $\begin{array}{l}\text { Chesbrough (di- } \\
\text { versas obras); }\end{array}$ & $\begin{array}{l}8 \\
\text { 8.1 Gestão } \\
\text { da Inovação }\end{array}$ \\
\hline & Fernandes, C. C. & $\begin{array}{c}\text { Analisar os benefícios da parceria } \\
\text { Universidade-Empresa no processo } \\
\text { de inovação e as melhorias advindas } \\
\text { dessa integração. }\end{array}$ & $\begin{array}{l}\text { Chesbrough; Va- } \\
\text { nhaverbeke; West }\end{array}$ & $\begin{array}{l}8 \\
\text { 8.1 Gestão } \\
\text { da Inovação }\end{array}$ \\
\hline $\begin{array}{c}2016 \\
(1)\end{array}$ & $\begin{array}{l}\text { Farias Junior, } \\
\text { I. V.; Abreu, P. } \\
\text { F.; Abreu, A. F.; } \\
\text { Silva, D. E. P.; } \\
\text { Muniz, E. C. L. }\end{array}$ & $\begin{array}{l}\text { Levantar práticas existentes na adoção } \\
\text { de IA em Ensino à Distância (EAD) em } \\
\text { uma Instituição de Ensino Superior. }\end{array}$ & $\begin{array}{l}\text { Chesbrough; } \\
\text { Stawkowitz }\end{array}$ & $\begin{array}{l}8 \\
8.1 \text { Gestão } \\
\text { da Inovação }\end{array}$ \\
\hline \multirow{2}{*}{$\begin{array}{c}2017 \\
(2)\end{array}$} & Oliveira, S. R. M. & $\begin{array}{c}\text { Contribuir para uma política de gestão } \\
\text { da inovação, apresentando a influência } \\
\text { de práticas de IA na prospecção de co- } \\
\text { nhecimento para criação de valor em } \\
\text { ambientes altamente complexos. }\end{array}$ & $\begin{array}{l}\text { Chesbrough; } \\
\text { Vanhaverbeke; } \\
\text { Huizingh }\end{array}$ & $\begin{array}{l}8 \\
\text { 8.1 Gestão } \\
\text { da Inovação }\end{array}$ \\
\hline & $\begin{array}{l}\text { Scaliza, J. A. A.; } \\
\text { Jugend, D.; } \\
\text { Alves, P. R. }\end{array}$ & $\begin{array}{l}\text { Realizar Revisão Bibliométrica na base } \\
\text { de dados Scopus, com as palavras- } \\
\text {-chave "Organizational Culture" e } \\
\text { "Open Innovation", objetivando pers- } \\
\text { pectivas de trabalhos futuros. }\end{array}$ & $\begin{array}{c}\text { Buschgens; Baus- } \\
\text { ch; Balkins; }\end{array}$ & $\begin{array}{l}8 \\
\text { 8.1 Gestão } \\
\text { da Inovação }\end{array}$ \\
\hline $\begin{array}{c}2018 \\
(1)\end{array}$ & $\begin{array}{l}\text { Martins, F. P.; } \\
\text { Rebehy, P. C. P. } \\
\text { W.; } \\
\text { Castro, J. M.; } \\
\text { Passador, C. S. }\end{array}$ & $\begin{array}{l}\text { Estudar a IA social e na administração } \\
\text { pública, sob a lente do construto ha- } \\
\text { ckathon, com o objetivo de clarificar o } \\
\text { papel que o evento tem na intersecção } \\
\text { entre IA e Administração Pública. }\end{array}$ & $\begin{array}{l}\text { Chesbrough; } \\
\text { Von Hippel }\end{array}$ & $\begin{array}{l}8 \\
\text { 8.1 Gestão } \\
\text { da Inovação }\end{array}$ \\
\hline
\end{tabular}




\begin{tabular}{|c|c|c|c|c|}
\hline \multirow{2}{*}{$\begin{array}{c}\mathbf{2 0 1 9} \\
\mathbf{( 2 )}\end{array}$} & $\begin{array}{c}\text { Agio, T. C.; } \\
\text { Canciglieri Junior, } \\
\text { O. }\end{array}$ & $\begin{array}{c}\text { Identificar as principais referencias } \\
\text { sobre métodos de maturidade com } \\
\text { foco na aplicação de IA em empresas } \\
\text { alimentícias. }\end{array}$ & $\begin{array}{c}\text { Chesbrough } \\
\text { (diversas obras); }\end{array}$ & $\begin{array}{c}8 \\
\text { 8.4 Gestão } \\
\text { de Projetos }\end{array}$ \\
\cline { 2 - 5 } & $\begin{array}{c}\text { Pusinhol, C. C.; } \\
\text { Amaral, D. C.; } \\
\text { Torkomian, A. L. } \\
\text { V. }\end{array}$ & $\begin{array}{c}\text { Descrever a gestão de um projeto de } \\
\text { IA entre uma empresa privada e uma } \\
\text { ICT, para o desenvolvimento de tecno- } \\
\text { logia, apontando abordagens utilizadas } \\
\text { e relacionando-as às práticas existen- } \\
\text { tes. }\end{array}$ & $\begin{array}{c}\text { Dahlander; Gann; } \\
\text { Conforto; } \\
\text { Amaral }\end{array}$ & $\begin{array}{c}8 \\
\text { 8.1 Gestão } \\
\text { da Inovação }\end{array}$ \\
\hline
\end{tabular}

Fonte: As autoras

Pode-se observar a concentração dos artigos nas áreas 7., "Gestão Estratégica e Organizacional", com 02 artigos e na 8, "Gestão do Conhecimento Organizacional" com 12 artigos.

As pesquisas tiveram a seguinte participação de IES por estado: $35 \%$ SP; $22 \% \mathrm{RS}$ e $7 \%$ distribuídos por MG, PR, SC, SE e AM. Dentre os pesquisadores das IES participantes $57 \%$ são de Universidades Federias, 29\% de Universidades de São Paulo, destes 50\% são da UNESP, e $14 \%$ de Universidades privadas.

O autor de principal destaque é Chesbrough com pesquisas no período de 2003 a 2012, de autoria própria ou em coautoria. Também aparece, por mais de uma vez, Vanhaverbeke.

Os principais assuntos abordados, relacionados à IA e de interesse das empresas e demais organizações são: gestão empresarial, gestão pública, hibridismo na gestão, métodos ágeis, cultura organizacional, educação, gestão de risco, gestão do conhecimento, integração universidade-empresa; cocriação, práticas organizacionais e localização de ideias inovadoras.

Dentre os artigos, alguns temas pesquisados merecem destaque: Lima Cohen e Rebouças (2011) ressaltam a importância de se investir no comportamento inovador dentro da organização enfatizando o desenvolvimento do capital humano. Rocha et al. (2011) analisam a cocriação, como forma de inovação aberta, utilizada através dos canais de comunicação entre clientes e empresa e a consideram valiosa em todas as fases do desenvolvimento do produto ou do serviço. Scherer e Ribeiro (2012) destacam a questão da propriedade intelectual do material gerado em programas de inovação aberta, com o intuito de evitar riscos e proteger as inovações geradas. Scaliza e Jugend (2014) apresentam aspectos do processo de inovação realizado com a participação de funcionários, não de P\&D e a utilização do relacionamento com clientes, para analisar expectativas, preferências e necessidades na aquisição de tecnologias externas. Cruz et al. (2015) atentam para a importância da gerência cautelosa, para evitar riscos e barreiras que interferem na lucratividade das organizações, decorrentes de suas iniciativas. Rebehy, Castro e Passador (2018) abordam os hackathons, eventos destinados a resolverem problemas reais das organizações nas quais se formam equipes que competem entre si para encontrar soluções, em geral visando a uma premiação; segundo os autores, o hackathon cívico se encontra na interface da IA, inovação social e administração pública. O artigo de Pusinhol, Amaral e Torkomian (2019) busca apurar a configuração e a existência de um método híbrido de 
gestão de projeto, na percepção de integrantes de equipes, vinculados a uma Instituição de Ciência e Tecnologia (ICT) e a uma empresa privada, em um processo de IA.

A busca nos Anais do SIMPEP de 2009 a 2019, apenas localizou artigos com conteúdo de EC a partir de 2017. São 12 artigos, publicados de 2017 a 2019, em crescimento no período, conforme apresentado no Quadro 2.

Quadro 2 - Artigos com conteúdo de Economia Circular de 2017 a 2019 nos Anais do SIMPEP

\begin{tabular}{|c|c|c|c|c|}
\hline Ano & Autores & Objetivos & $\begin{array}{c}\text { Principais } \\
\text { Aportes }\end{array}$ & $\begin{array}{c}\text { Áreas } \\
\text { Sub áreas }\end{array}$ \\
\hline \multirow{3}{*}{$\begin{array}{c}2017 \\
(3)\end{array}$} & $\begin{array}{l}\text { Zomer, T. T. S.; } \\
\text { Magalhães, L. A.; } \\
\text { Zancul, E. S.; } \\
\text { Cauchick-Miguel, } \\
\text { P. A. }\end{array}$ & $\begin{array}{l}\text { Explorar as capabilities necessárias para } \\
\text { transição para modelos de negócio susten- } \\
\text { táveis e circulares em empresas de manu- } \\
\text { fatura, para guiar adoção e implementação } \\
\text { prática e contribuir para o desenvolvimento } \\
\text { da teoria. }\end{array}$ & $\begin{array}{l}\text { Lewandowsky; } \\
\text { De Los Rios; } \\
\text { Charnley; Ghi- } \\
\text { sellini; Cialani; } \\
\text { Ugliati; EMF }\end{array}$ & $\begin{array}{l}11 \\
11.4 \text { Susten- } \\
\text { tab. e Sist. } \\
\text { Indicadores }\end{array}$ \\
\hline & $\begin{array}{l}\text { Garcia, G. C.; } \\
\text { Ogawa, A. P. S.; } \\
\text { Kissimoto, K. O.; } \\
\text { Mattos, C. A. }\end{array}$ & $\begin{array}{c}\text { Analisar e ampliar a compreensão da rela- } \\
\text { ção entre a produção de literatura na esfera } \\
\text { da EC e a prática da Logística Reversa. }\end{array}$ & $\begin{array}{l}\text { Geng;Dobers- } \\
\text { tein; } \\
\text { Stahel; Ro- } \\
\text { gers; Tibben- } \\
\text {-Lembke; EMF }\end{array}$ & $\begin{array}{l}11 \\
11.5 \text { Desenv. } \\
\text { Sustent.em } \\
\text { Eng. Prod. }\end{array}$ \\
\hline & $\begin{array}{c}\text { Tiossi, F. M.; } \\
\text { Simon, A. T.; } \\
\text { Marques, C. S. A. }\end{array}$ & $\begin{array}{c}\text { Apresentar RSL sobre a EC, período 1998- } \\
\text { 2017, com apoio bibliométrico e identificar os } \\
\text { avanços das pesquisas na área, levantando } \\
\text { temáticas mais abordadas e novos parâme- } \\
\text { tros de busca. }\end{array}$ & $\begin{array}{l}\text { Zhu; Geng; } \\
\text { Lai; Lacy; Rut- } \\
\text { qvist; EMF. }\end{array}$ & $\begin{array}{l}11 \\
11.5 \text { Desenv. } \\
\text { Sustent.em } \\
\text { Eng. Prod. }\end{array}$ \\
\hline \multirow{4}{*}{$\begin{array}{c}2018 \\
(4)\end{array}$} & $\begin{array}{l}\text { Fujita, T.; } \\
\text { Yoshi, C. V. H.; } \\
\text { Arbex, M. A. }\end{array}$ & $\begin{array}{l}\text { Desenvolver revisão bibliográfica sobre a } \\
\text { EC, fornecendo visão teórica da origem, } \\
\text { dos modelos econômicos e dos padrões de } \\
\text { relacionamento que desafiam os modelos } \\
\text { vigentes. }\end{array}$ & $\begin{array}{l}\text { Lieder; Rachid; } \\
\text { Ghisellini; Cia- } \\
\text { lani; Ugliati; } \\
\text { EMF }\end{array}$ & $\begin{array}{c}9 \\
9.1 \text { Gestão } \\
\text { de Recursos } \\
\text { Naturais }\end{array}$ \\
\hline & $\begin{array}{l}\text { Campese, C.; } \\
\text { Iwasaka, F. Y.; } \\
\text { Bertassini, A. C.; } \\
\text { Costa, J. M. H.; } \\
\text { ometto, A. R. }\end{array}$ & $\begin{array}{l}\text { Analisar } 9 \text { estudos de caso, de acordo com } \\
\text { a estrutura "ReSOLVE", composta por seis } \\
\text { ações voltadas ao negócio: Regenerar, } \\
\text { Compartilhar, Otimizar, Circular, Virtualizar } \\
\text { e Trocar (WEBSTER, 2015) que traduz os } \\
\text { princípios da EC em ações práticas. }\end{array}$ & $\begin{array}{l}\text { Geng; Macar- } \\
\text { thur; Webster; } \\
\text { EMF. }\end{array}$ & $\begin{array}{c}9 \\
\text { 9.3 Prod. } \\
\text { mais Limpa e } \\
\text { Ecoeficiente }\end{array}$ \\
\hline & $\begin{array}{l}\text { Tiossi, F. M.; } \\
\text { Simon, A. T. }\end{array}$ & $\begin{array}{l}\text { Identificar as contribuições efetivas e os no- } \\
\text { vos quesitos da EC para o desenvolvimento } \\
\text { da Sustentabilidade. }\end{array}$ & $\begin{array}{l}\text { Lacy; Rutqvist; } \\
\text { Ghisellini; } \\
\text { Cialani; Ugliati; } \\
\text { Shen; Qi; EMF }\end{array}$ & $\begin{array}{l}11 \\
11.5 \text { Desenv. } \\
\text { Sustent.em } \\
\text { Eng. Prod. }\end{array}$ \\
\hline & $\begin{array}{c}\text { Dias, B. C.; } \\
\text { Thomé, A. M. T. }\end{array}$ & $\begin{array}{c}\text { Identificar abordagens sobre a relação entre } \\
\text { a EC e a Industria } 4.0 \text { (I 4.0), e as vantagens } \\
\text { e desvantagens da adoção dos princípios } \\
\text { desta indústria na busca de um sistema pro- } \\
\text { dutivo mais sustentável. }\end{array}$ & $\begin{array}{l}\text { Stahel; Bres- } \\
\text { sanelli; Adro- } \\
\text { degari; Pero- } \\
\text { na; Saccani; } \\
\text { EMF } \\
\end{array}$ & $\begin{array}{l}11 \\
11.5 \text { Desenv. } \\
\text { Sustent.em } \\
\text { Eng. Prod.. }\end{array}$ \\
\hline \multirow{3}{*}{$\begin{array}{c}2019 \\
(5)\end{array}$} & $\begin{array}{l}\text { Silva, K. A.; Moto- } \\
\text { miya, A. V. A.; } \\
\text { Melo, I. C.; } \\
\text { Ferraz, D.; } \\
\text { Rebelatto, D. A. } \\
\text { N. }\end{array}$ & $\begin{array}{c}\text { Analisar a agricultura, mapeando a produ- } \\
\text { ção de soja no estado de MS, abordando as } \\
\text { atividades de produção, desde o preparo do } \\
\text { solo à colheita, correlacionando os conceitos } \\
\text { de agricultura de precisão, plantio direto e a } \\
\text { EC, em busca de um sistema produtivo mais } \\
\text { sustentável. }\end{array}$ & $\begin{array}{c}\text { Bressanelli; } \\
\text { Adrodegari; } \\
\text { Perona; Sac- } \\
\text { cani; Bilitwski; } \\
\text { EMF }\end{array}$ & $\begin{array}{c}9 \\
\text { 9.3 Prod. } \\
\text { mais Limpa e } \\
\text { Ecoeficiente }\end{array}$ \\
\hline & Fiorini, P. C. & $\begin{array}{l}\text { Identificar, através de RSL, como a indústria } \\
4.0 \text { pode contribuir para aumentar a produti- } \\
\text { vidade, agilidade e criação de um ambiente } \\
\text { de negócios em modelo de EC. }\end{array}$ & $\begin{array}{l}\text { Geissdoerfer; } \\
\text { Morioka; Car- } \\
\text { valho; Evans; } \\
\text { EMF }\end{array}$ & $\begin{array}{c}9 \\
9.3 \text { Prod. } \\
\text { mais Limpa e } \\
\text { Ecoeficiente }\end{array}$ \\
\hline & $\begin{array}{l}\text { Ribeiro, P. C. C.; } \\
\text { Amaral, P. R. B.; } \\
\text { Rodrigues, L. B. }\end{array}$ & $\begin{array}{l}\text { Identificar o estado da arte dos temas EC e } \\
\text { Avaliação do Ciclo de Vida, relacionando- } \\
\text {-os com a Sustentabilidade e a Gestão da } \\
\text { Cadeia de Suprimentos (GCS). }\end{array}$ & $\begin{array}{l}\text { Deza; San- } \\
\text { chez; } \\
\text { EMF }\end{array}$ & $\begin{array}{l}11 \\
11.5 \text { Desenv. } \\
\text { Sustent.em } \\
\text { Eng. Prod.. }\end{array}$ \\
\hline
\end{tabular}




\begin{tabular}{|c|c|c|c|c|}
\hline $\begin{array}{c}\text { Vido, M.; } \\
\text { Lucato, W. W.; } \\
\text { Martens, W. L. }\end{array}$ & $\begin{array}{c}\text { Identificar os estudos sobre a relação entre } \\
\text { EC e indústria 4.0 (I4.0) na literatura e sin- } \\
\text { tetizar o conhecimento, nos últimos 3 anos, } \\
\text { sobre a relação entre os conceitos. }\end{array}$ & $\begin{array}{c}\text { Urbinati; Chia- } \\
\text { roni; Chiesa; } \\
\text { EMF }\end{array}$ & $\begin{array}{c}11.5 \text { Desenv. } \\
\text { Sustent.em } \\
\text { Eng. Prod.. }\end{array}$ \\
\cline { 2 - 5 } & $\begin{array}{c}\text { Stefano, E.; } \\
\text { Lima, F. R. N.; } \\
\text { Nogueira, S.M.S.; } \\
\text { Raposo, L. M.; } \\
\text { Jesus, V. S. }\end{array}$ & $\begin{array}{c}\text { Efetuar Revisão bibliográfica sobre EC e sua } \\
\text { aplicação, com a apresentação de estudos } \\
\text { de caso (2 europeus e 3 em empresas no } \\
\text { Brasil), mostrando a importância da EC } \\
\text { para: o melhor gerenciamento dos recursos } \\
\text { disponíveis na natureza e para evidenciar a } \\
\text { aplicação desse modelo de produção para } \\
\text { geração de lucro e visibilidade da empresa } \\
\text { perante a sociedade. }\end{array}$ & $\begin{array}{c}\text { Bimbati; Lei- } \\
\text { tão; EMF }\end{array}$ & $\begin{array}{c}11.5 \text { Desenv. } \\
\text { Sustent.em } \\
\text { Eng. Prod. }\end{array}$ \\
\hline
\end{tabular}

Fonte: as autoras

Pode-se observar a concentração dos artigos sobre EC nas áreas 11, "Engenharia de Produção, Sustentabilidade e Responsabilidade Social", com 8 artigos e na 9, "Gestão Ambiental" com 4 artigos.

As pesquisas tiveram a seguinte participação de IES por estado: $64 \%$ de SP; $22 \%$ do RJ e 7\% igualmente para o estado do PR e de SC, não havendo participação de outros estados como no caso da IA com contribuições de quase todas as regiões do Brasil.

Ellen Macarthur Foudantion (EMF) constitui um dos principais aportes teóricos, assim como Geng, Doberstein, Lai, Bressanelli, Adrodegari, Perona, Saccani, Ghisellini, Cialanie e Ugliati.

Os principais assuntos abordados relacionados à EC são: logística reversa, indústria 4.0, agricultura de precisão, economia ambiental, cadeia de suprimentos, tecnologias digitais (IoT, Big Data, computação nas nuvens) produção mais limpa, vantagens competitivas.

A partir de RSL envolvendo EC, em duas décadas, Tiossi et al. (2017) fornecem informações relevantes para os que se iniciam nessa área de conhecimento. Dentre os resultados: listam alguns países responsáveis por publicações nessa área: China, responsável por 75\%, com 354 pesquisas; Inglaterra com 29; Holanda com 15; EUA e Alemanha com 14; Itália com 12; Bélgica com 11; Romênia com 10; Espanha com 8 e Polônia com 6. O pesquisador identificado com maior volume de estudos sobre EC foi Yong Geng e o Journal of Cleaner Production figura com aproximadamente $10 \%$ do total geral de publicações.

Yoshi e Arbex (2018) concluem que a chave do sucesso para a EC é estar embasada em políticas. Dias e Thomé (2018) afirmam que a China foi o país que mais publicou sobre EC e Indústria 4.0 nos últimos 2 anos; há um alto potencial da Industria 4.0 para garantir métodos de produção mais sustentáveis. As tecnologias da Indústria 4.0 fornecem a base para impulsionar a transição da economia linear para a circular (VIDO et al., 2019) possibilitando novos modelos de negócios (FIORINI,2019).

Da análise dos artigos verificou-se que ambos os temas, IA e EC, possuem diferentes práticas, podem gerar novos modelos de negócios, dependem de diversos atores e de uma mudança de cultura. A IA, segundo Chesbrough (2020), é viável, está em pleno desenvolvimento e transformando-se ao longo do tempo, assim como a EC (KANGER; SHOT, 2018) e o bom desempenho econômico pode ser obtido através de uma produção que não 
degrade o meio ambiente (GENG et al., 2011).

\section{CONSIDERAÇÕES FINAIS}

O impacto das medidas de contenção ao coronavírus pode resultar em um isolamento muito mais nocivo à economia que o imposto para evitar contaminação, tornando as empresas dependentes apenas de suas ações e pesquisas internas para o enfrentamento de todos os problemas organizacionais aliados aos advindos do combate ao COVID-19.

O objetivo deste trabalho, em unir as publicações de IA e EC do SIMPEP na última década foi realizado e segundo Pierroni, MacAlone e Pigosso (2019) à medida que a EC ganha atenção de governos, organizações e IES, a inovação para um modelo de negócios circular torna-se fundamental para sustentar vantagem competitiva das empresas.

A pluralidade de aplicações, pesquisas e estudos empíricos de ambos os temas pode contribuir em dois aspectos para as organizações: para a redução do isolamento de conhecimento científico e também para a aproximação de organizações geradoras desse conhecimento, as IES e ICT's, podendo ser esta ação determinante para a manutenção da competitividade, não apenas agora e no pós-pandemia, mas o suficiente para promover o desenvolvimento sustentável do país, criando produtos realmente inovadores e circulares.

\section{REFERÊNCIAS}

AGIO, T. C.; CANCIGLIERI JUNIOR, O. Aplicação da inovação aberta em empresas alimentícias: uma revisão sistemática da literatura. In: SIMPÓSIO DE ENGENHARIA DE PRODUÇÃO, SIMPEP, 26, 2019, Bauru/SP. Anais... Bauru/SP: UNESP, 2019.

BERTO, R. M. V. S.; NAKANO, D. N. Revisitando a produção científica nos Anais do Encontro Nacional de Engenharia de Produção. Production Journal, v. 24, n. 1, p. 225-232, 2014.

CAMPESE, C.; IWASAKA, F. Y.; BERTASSINI, A. C.; COSTA, J. M. H.; OMETTO, A. R. Ações da teoria de economia circular colocadas em prática. In: SIMPÓSIO DE ENGENHARIA DE PRODUÇÃO, SIMPEP, 25, 2018, Bauru/SP. Anais... Bauru/SP: UNESP, 2018.

CHESBROUGH, H. The era of open innovation. MIT Sloan Management Review, 44(3), 35-41 2003.

CHESBROUGH, H. Open innovation: the new imperative for creating and profiting from technology. Boston: Harvard Business School Press, 2006.

CHESBROUGH, $\mathrm{H}$. To recover faster from Covid-19, open up: Managerial implications from an open innovations perspective Industrial Marketing Management, https://doi.org/10.1016/j. indmarman.2020.04.010.

CONFORTO, E. C.; AMARAL, D. C.; SILVA, S. L. D. Roteiro para revisão bibliográfica sistemática: aplicação no desenvolvimento de produtos e gerenciamento de projetos. In: CONGRESSO BRASILEIRO DE GESTÃO DE DESENVOLVIMENTO DE PRODUTO, 8- CBGDP. Anais... Porto Alegre, 2011. [R.S.]

CRUZ, N. J. T.; LEZANA, Á. G. R.; SANTOS, P. C. F.; ZANCAN, C.; DANTAS, A. B. Gestão de riscos da inovação aberta na concepção de empreendedores. In: SIMPÓSIO DE ENGENHARIA DE PRODUÇÃO, SIMPEP, 22, 2015, Bauru/SP. Anais... Bauru/SP: UNESP, 2015

CUNICO E.; CIRANI, C.B.S.; LOPES, E.L.; JABBOUR, C.J.C. Eco-innovation and technological 
cooperation in cassava processing companies: structural equation modeling. Revista de Administração, 52 (2017) 36-46, 2017.

DIAS, B. C.; THOMÉ, A. M. T. A indústria 4.0 no contexto da economia circular - uma revisão. In: SIMPÓSIO DE ENGENHARIA DE PRODUÇÃO, SIMPEP, 25, 2018, Bauru/SP. Anais... Bauru/SP: UNESP, 2018

EMF Economia Circular. Disponível em: Ellen Macarthur Foundation <https://www. ellenmacarthurfoundation.org/pt/economia-circular/conceito > Acessado em: 02 de jul. de 2020.

FARIAS JUNIOR, I. V.; ABREU, P. F.; ABREU, A. F.; SILVA, D. E. P.; MUNIZ, E. C. L. A inovação aberta na educação a distância (EAD): um levantamento das práticas existentes e estudo da gestão das ideias em uma instituição de ensino superior. In: SIMPÓSIO DE ENGENHARIA DE PRODUÇÃO, SIMPEP, 23, 2016, Bauru/SP. Anais... Bauru/SP: UNESP, 2016.

FERNANDES, C. C. Os benefícios da integração universidade-empresa para a inovação tecnológica: um estudo de caso BVTEC.In: SIMPÓSIO DE ENGENHARIA DE PRODÚÇÃO, SIMPEP, 22, 2015, Bauru/SP. Anais... Bauru/SP: UNESP, 2015.

FERRARI, A. G.; SCALIZA, J. A. A.; JUGEND, D. The landscape of open innovation in Brazil: an analysis of the recent literature. Production, v29, e20190018, 2019. DOI: 10.1590/01036513.20190018.

FIORINI, P. C. Mapeando a sinergia entre indústria 4.0 e economia circular: uma revisão da literatura. In: SIMPÓSIO DE ENGENHARIA DE PRODUÇÃO, SIMPEP, 26, 2019, Bauru/SP. Anais... Bauru/SP: UNESP, 2019.

FUJITA, T.; YOSHI, C. V. H.; ARBEX, M. A. Uma revisão sobre a economia circular: a transição para um sistema econômico e ambiental sustentável. In: SIMPÓSIO DE ENGENHARIA DE PRODUÇÃO, SIMPEP, 25, 2018, Bauru/SP. Anais... Bauru/SP: UNESP, 2018.

GARCIA, G. C.; OGAWA, A. P. S.; KISSIMOTO, K. O.; MATTOS, C. A. A relação entre economia circular e logística reversa: um estudo bibliométrico. In: SIMPÓSIO DE ENGÉNHARIA DE PRODUÇÃO, SIMPEP, 24, 2017, Bauru/SP. Anais... Bauru/SP: UNESP, 2017.

GENG, Y.; FU, J.; SARKIS, J.; XUE, B. Towards a national circular economy indicator system in China: An evaluation and critical analysis. Journal of Cleaner Production. v. 23, p. 216-224, 2011.

JABBOUR, C. J. C. Unlocking the circular economy through new business models based on largescale data: An integrative framework and research agenda. Technological Forecasting \& Social Change Vol. 144, July 2019, pages 546-552.

KANGER, L., SCHOT, J., Deep transitions: theorizing the long-term patterns of socio-technical change. Environ. Innov. Soc. Trans. Vol. 32, Sept. 2018, pages 7-21.

KOMESU, A. H.; NASCIMENTO, C. M.; RIBEIRO JUNIOR, H. J.; FIGUEIREDO, V. G. C. A gestão do conhecimento e a inovação aberta como ferramentas diferenciais no mercado competitivo: uma visão da aplicação em Itabira-MG. In: SIMPÓSIO DE ENGENHARIA DE PRODUÇÃO, SIMPEP, 21, 2014, Bauru/SP. Anais... Bauru/SP: UNESP, 2014.

LIMA, E. B.; COHEN, M. F.; REBOUÇAS, W. F. Um estudo sobre a aderência das práticas organizacionais ao modelo de inovação aberta: identificação das variáveis de pesquisa. In: SIMPÓSIO DE ENGENHARIA DE PRODUÇÃO, SIMPEP, 18, 2011, Bauru/SP. Anais... Bauru/SP: UNESP, 2011.

MAGNANO, P. F.; FETTERMANN, D. C.; ECHEVESTE, M. E. S. Ideias inovadoras: como encontrá-las fora da empresa? In: SIMPÓSIO DE ENGENHARIA DE PRODUÇÃO, SIMPEP, 17, 2010, Bauru/SP. Anais... Bauru/SP: UNESP, 2010.

MARTINS, F. P.; REBEHY, P. C. P. W.; CASTRO, J. M.; PASSADOR, C. S. Inovação aberta na administração pública: uma revisão sob a lente do engajamento cívico em hackathons. In: SIMPÓSIO DE ENGENHARIA DE PRODUÇÃO, SIMPEP, 25, 2018, Bauru/SP. Anais... Bauru/SP: 
UNESP, 2018.

MATOS, S.; MIRANDA, L. Em Foco IBRE: Cenários para o crescimento para o PIB do Brasil em 2020. IBRE. Boletim Macro, março, 2020.

MORAES, R.F. Prevenindo conflitos Sociais violentos em Tempos de pandemia: Garantia da renda, manutenção da saúde mental e comunicação efetiva. DIEST - Diretoria de Estudos e Políticas do Estado, das Instituições e da Democracia. Nota Técnica n²7 IPEA, 2020

OECD - ORGANISATION FOR ECONOMIC CO-OPERATION AND DEVELOPMENT. Coronavirus: The World Economy at Risk (OECD Interim Economic Assessment). OECD, 2020. Disponivel em: <https://www.oecd.org/berlin/publikationen/Interim-Economic-Assessment-2March-2020.pdf>.

OLIVEIRA, S. R. M. A próxima fronteira: inovação aberta e prospecção de conhecimento em ambientes de alta complexidade - rumo a criação de valor nas indústrias inteligentes. In: SIMPÓSIO DE ENGENHARIA DE PRODUÇÃO, 24- SIMPEP, 2017, Bauru/SP. Anais... Bauru/SP: UNESP, 2017.

PEREIRA, G. S.; FERREIRA, G. O.; BEZERRA, B. S.; CREPALDI, A. F. Logística reversa no brasil: uma revisão estruturada da literatura. In: SIMPÓSIO DE ENGENHARIA DE PRODUÇÃO, SIMPEP, 25, 2018, Bauru/SP. Anais... Bauru/SP: UNESP, 2018.

PIERONI, M.P.P.; MCALOONE, T.C.; PIGOSSO, D.C.A. Business model innovation for circular economy and sustainability: A review of approaches. Journal of Cleaner Production, vol 215, 1 April 2019, Pages 198-216.

PUSINHOL, C. C.; AMARAL, D. C.; TORKOMIAN, A. L. V. O hibridismo na gestão de um projeto de inovação aberta entre uma instituição de ciência e tecnologia e uma empresa privada.In: SIMPÓSIO DE ENGENHARIA DE PRODUÇÃO, SIMPEP, 26, 2019, Bauru/SP. Anais... Bauru/SP: UNESP, 2019

RIBEIRO, P. C. C.; AMARAL, P. R. B.; RODRIGUES, L. B. O estado da arte dos temas economia circular e avaliação do ciclo de vida na gestão da cadeia de suprimentos. In: SIMPÓSIO DE ENGENHARIA DE PRODUÇÃO, SIMPEP, 26, 2019, Bauru/SP. Anais... Bauru/SP: UNESP, 2019.

ROCHA, E. A. M.; ANJOS, F. E. V.; DOMINGUES, J.; DA SILVA, M. G. Análise da relação entre cocriação e estratégia de produção. In: SIMPÓSIO DE EN̄GENHARIA DE PRODUÇÃO, SIMPEP, 18, 2011, Bauru/SP. Anais... Bauru/SP: UNESP, 2011.

ROTHER, E. T. Revisão sistemática versus revisão narrativa. Editorial. Acta Paul Enferm, 2007; 20(2) vi. 2007. Disponível em: <http://www.scielo.br/pdf/ape/v20n2/a01v20n2.pdf> Acesso em: 07 abr. 2018.

SAUNILA, M. Innovation capability in achieving higher performance: perspectives of management and employees. Technology Analysis \& Strategic Management, vol 29, 2016, Pages 198-216.

SCALIZA, J. A. A.; JUGEND, D. Apresentação de estudos sobre práticas de open innovation: qual a prática mais celebrada pela academia e quais as menos estudadas. In: SIMPÓSIO DE ENGENHARIA DE PRODUÇÃO, SIMPEP, 22, 2015, Bauru/SP. Anais... Bauru/SP: UNESP, 2015.

SCALIZA, J. A. A.; JUGEND, D.; ALVES, P. R. Cultura organizacional e open innovation: estudos e perspectivas segundo levantamento bibliográfico. In: SIMPÓSIO DE ENGENHARIA DE PRODUÇÃO, SIMPEP, 24, 2017, Bauru/SP. Anais... Bauru/SP: UNESP, 2017.

SCHERER, J. O.; RIBEIRO, J. L. D. Identificação das características importantes do escopo de um projeto de inovação aberta via portal web. In: SIMPÓSIO DE ENGENHARIA DE PRODUÇÃO, SIMPEP, 19, 2012, Bauru/SP. Anais... Bauru/SP: UNESP, 2012.

SILVA, K. A.; MOTOMIYA, A. V. A.; MELO, I. C.; FERRAZ, D.; REBELATTO, D. A. N. Uma análise sobre a relação entre a cadeia produtiva da soja com a economia circular, agricultura de precisão e plantio direto. In: SIMPÓSIO DE ENGENHARIA DE PRODUÇÃO, SIMPEP, 26, 2019, Bauru/SP. 
Anais... Bauru/SP: UNESP, 2019.

SLACK, N.; CHAMBER, S.; HARDLAND, C.; HARRISON, A. e JOHNSTON, R. Administração da Produção. São Paulo: Atlas, 1999.

STEFANO, E.; LIMA, F. R. N.; NOGUEIRA, S.M.S.; RAPOSO, L. M.; JESUS, V. S. Economia circular na sociedade 4.0. in: SIMPÓSIO DE ENGENHARIA DE PRODUÇÃO, SIMPEP, 26, 2019, Bauru/SP. Anais... Bauru/SP: UNESP, 2019

TIOSSI, F. M.; SIMON, A. T. Economia circular: suas contribuições para o desenvolvimento da sustentabilidade. In: SIMPÓSIO DE ENGENHARIA DE PRODUÇÃO, SIMPEP, 25, 2018, Bauru/ SP. Anais... Bauru/SP: UNESP, 2018

TIOSSI, F. M.; SIMON, A. T.; MARQUES, C. S. A. Economia circular: uma revisão sistemática da literatura. In: SIMPÓSIO DE ENGENHARIA DE PRODUÇÃO, SIMPEP, 24, 2017, Bauru/SP. Anais... Bauru/SP: UNESP, 2017.

VIDO, M.; LUCATO, W. C.; MARTENS, M. L. Estabelecimento de uma revisão da economia circular através da indústria 4.0: mapeamento da pesquisa atual e compreensão. In: SIMPÓSIO DE ENGENHARIA DE PRODUÇÃO, SIMPEP, 26, 2019, Bauru/SP. Anais... Bauru/SP: UNESP, 2019.

ZOMER, T. T. S.; MAGALHÃES, L. A.; ZANCUL, E. S.; CAUCHICK-MIGUEL, P. A. Análise das capabilities necessárias para implementação de modelos de negócio circulares: um estudo empírico em uma organização do setor de linha branca. In: SIMPÓSIO DE ENGENHARIA DE PRODUÇÃO, SIMPEP, 24, 2017, Bauru/SP. Anais... Bauru/SP: UNESP, 2017. 


\section{Resumo}

A pandemia causada pelo novo coronavírus disseminou-se rapidamente em todo o globo. Devido à agressividade do vírus e à inexistência de vacinas e medicamentos específicos, governos de diversos países, inclusive o do Brasil, adotaram estratégias de contenção que impactaram diretamente na vida social e profissional das pessoas. Assim, este estudo tem por objetivo analisar a vida profissional dos estudantes de uma faculdade de tecnologia do interior do estado de São Paulo. A importância do estudo é justificada pelo momento atual e pela necessidade de analisar os reflexos de uma pandemia na vida profissional de estudantes de nível superior. Para alcançar os objetivos realizou-se um estudo bibliográfico e uma pesquisa conduzida pelo método survey. De acordo com os resultados, conclui-se que a pandemia ocasionou modificações significantes tanto na vida profissional dos estudantes quanto no ambiente de trabalho das empresas.

Palavras-chave: mercado de trabalho. emprego. pandemia. COVID-19. inovação.

\section{Alistragt}

The pandemic caused by the new coronavirus has spread quickly around the world. due to the aggressiveness of the virus and to the lack of specific vaccines and medications, the governments in several countries, including Brazil, adopted containment strategies that directly impacted people's social and professional lives. This study aims to analyze the professional lives of students at a technology college in the interior of the state of São Paulo. The importance of the study is justified by the current moment and by the need to analyze the effects of a pandemic on the professional lives of higher education students. To achieve the objectives, a bibliographic study and a survey conducted by the survey method were carried out. According to the results, it is concluded that the pandemic caused significant changes both in the students' professional lives and in the work environment of the companies.

Keywords: labor market. employed. pandemic. COVID-19. innovation. 


\section{INTRODUÇÃO}

O primeiro caso do novo coronavírus da síndrome respiratória aguda grave 2 (SARS-CoV-2) e que provoca a doença COVID-19, ocorreu na cidade de Wuhan, na China central e assim disseminou-se rapidamente por todos os continentes. No dia 11 de março de 2020, a Organização Mundial da Saúde declarou estado de pandemia da doença. Países como Estados Unidos, Itália, Espanha, China e Brasil foram os países com maior número de casos, demonstrando que o vírus se expande agressivamente em locais com distintas características sociais e econômicas (SARTI et al., 2020).

O percurso e a gravidade desta epidemia fizeram com que o governo de diversos países adotasse intensas intervenções, como estratégias de lockdown, com a finalidade de conter a infecção de novos indivíduos e diminuir sua mortalidade. Porém, essas medidas trouxeram diversas mudanças na vida das pessoas e da sociedade em torno do mundo. Além de toda questão na adaptação à nova etiqueta de higiene, houve também impacto da epidemia na dinâmica econômica, social, política e cultural da população mundial, logo, na vida pessoal e profissional de muitos indivíduos durante este período de pandemia (PARMET, W. E.; SINHA, M. S., 2020).

Neste cenário surge uma questão a ser pesquisada: Qual é o perfil profissional dos estudantes de uma específica Instituição de Ensino Superior (IES) na cidade em São Carlos-SP durante a pandemia de COVID-19?

Diante deste contexto, este trabalho tem o objetivo de analisar a vida profissional dos estudantes da Faculdade de Tecnologia (FATEC) da cidade de São Carlos, SP em tempos de pandemia da COVID-19.

Para se alcançar o objetivo geral, alguns objetivos específicos tornam-se necessários, tais como: identificar o perfil dos estudantes da FATEC da cidade de São Carlos, SP, verificar como a pandemia da COVID-19 interferiu na vida profissional dos alunos da FATEC da cidade de São Carlos, SP e analisar como as empresas têm enfrentado as consequências da pandemia da COVID-19.

A justificativa para sustentar o presente artigo reside na importância que o tema possui para a sociedade atual, usando uma instituição de ensino superior como amostra no estudo dos reflexos de uma pandemia na vida profissional de diversos indivíduos.

Este estudo foi dividido em seções que se inicia com esta introdução, que apresenta uma visão geral da pesquisa. A segunda seção contém toda a base teórica que fundamenta o estudo. A metodologia será abordada na terceira seção. A quarta seção contém os resultados obtidos na pesquisa e a análise dos resultados. Por último, na quinta seção, as considerações finais serão apresentadas.

\section{REFERENCIAL TEÓRICO}

As pessoas buscam uma qualificação ao ingressar em um curso superior, isto é, um diferencial entre aos demais que não possuem um diploma universitário. Muitas questões influenciam na escolha do curso desejado, que vão desde a área de atuação até à remu- 
neração.

A FATEC é uma instituição de ensino superior pública, pertencente ao Centro Estadual de Educação Tecnológica Paula Souza, está presente em 67 municípios paulistas, sendo um deles na cidade de São Carlos - SP. Nesta unidade existem dois cursos de graduação: Tecnologia em Gestão Empresarial e Tecnologia em Gestão de Recursos Humanos. Ambos os cursos possuem o objetivo de formar profissionais capacitados para trabalhar na gestão de diversos setores de uma organização privada, independente do seu tamanho ou atuação (Fonte: Portal do Centro Paula Souza).

As mudanças no mercado de trabalho têm afetado diretamente a vida profissional dos trabalhadores. As organizações têm apresentado muitas variações ao longo do tempo. Fatores como: "o mundo em acelerada mudança, o impacto do desenvolvimento tecnológico, as novas formas de organização e configuração empresarial, novos produtos e serviços e novos processos de trabalho". (CHIAVENATO, 2014, p. 84). Os reflexos destas mudanças no mercado de trabalho apresentam deficiências ao desempenhar atividades dentro das empresas. Sendo assim, nesta pandemia do século XXI, mais do que nunca, a humanidade está passando por aceleradas mudanças que vão impactar não somente nas atividades de dentro de uma empresa, mas também na nossa vida como um todo.

Chesbrough (2020) afirma que a inovação será determinante para que a economia se recupere das consequências causadas pela pandemia, que testou em todo o mundo o sistema de saúde pública e colocará em teste o sistema econômico mundial.

Com a atual crise política e econômica que o Brasil tem passado, as notícias que circulam nos meios de comunicação como jornais, televisão e redes sociais mostram diariamente quais são as consequências ocasionadas por essa recessão, refletindo diretamente na vida profissional de diversos brasileiros e na economia em geral (Debortoli et al., 2019).

Com a disseminação do COVID-19 em escala mundial, a humanidade enfrenta um dos piores momentos de sua história. O crescimento acelerado de infectados no Brasil e no mundo estão cercados por um cenário extremamente preocupante e repleto de incertezas que tendem a arrastar a economia mundial a um processo de recessão (MATOS; MIRANDA, 2020). Nota-se que mesmo com o avanço da Ciência, ainda não é possível combater os efeitos nocivos da COVID-19, uma vez que nem a ciência, tampouco a economia e a sociedade estavam preparadas para esta pandemia.

Segundo os dados divulgados pelo portal do Johns Hopkins University School of Medicine, o número de infectados por SARsCov-2 é de 14.126 .035 pessoas em todo o mundo (até a data de 18 de julho de 2020). Neste momento, todos procuram meios de conscientizar a população sobre a gravidade da pandemia, e suas consequências refletirão fortemente com crises em diversos setores como político, econômico e científico.

Em momento de crise surgem oportunidades e inovações, assim durante o enfrentamento desta pandemia surgiram nas empresas algumas estratégias emergentes para as vendas de produtos e comercialização de bens como uma tentativa de manter o faturamento, ou pelo menos parte dele. De acordo com Bertero (1980), essas estratégias bem sucedidas tendem a suavizar os efeitos econômicos e financeiros decorrentes da interrupção das atividades produtivas e, portanto, aliviar um os efeitos da crise nas empresas, visto que o 
futuro ainda está repleto de dúvidas e incertezas.

Com todos os aspectos negativos da pandemia, há ainda de se considerar um lado positivo que, segundo Chesbrough (2020), é o fato de a pandemia estimular a inovação.

\section{MATERIAL E MÉTODOS}

Para obter todas as informações necessárias, por meio do método de pesquisa qualitativa, foi realizado um estudo bibliográfico, em revistas, sites e trabalhos acadêmicos sobre o assunto proposto, com a finalidade de assegurar um embasamento teórico para este trabalho. Segundo Gil (2010), uma pesquisa é baseada por materiais já elaborados como artigos científicos e livros sobre o tema que será pesquisado, sendo assim, esse procedimento foi feito para unir distintos conhecimentos acerca do tema central desta pesquisa.

Posteriormente, foi conduzido um questionário, de caráter quantitativo, elaborado de forma condizente com artigos científicos e aplicados pelo método survey. Classifica-se esta pesquisa como um estudo de caso, uma vez que os dados foram coletados por meio de análise dos questionários. Este procedimento é conceituado por Gil (2010, p. 37) como "estudo profundo e exaustivo de um ou de poucos objetivos, de maneira que permita o seu amplo e detalhado conhecimento".

O convite para que os respondentes participassem do presente estudo ocorreu por uma rede social de mensagens instantâneas. Vinte e sete perguntas compuseram o questionário e foram encaminhados aos participantes por meio do link de um formulário no Google, durante o período de 20 a 23 de maio de 2020. A seleção do grupo amostral foi composta por graduandos regularmente matriculados no ano letivo de 2020 na FATEC São Carlos. Pessoas que não possuíam uma rede social de mensagens instantâneas acabaram ficando impossibilitadas de participa.

Os dados foram analisados por meio de estatística descritiva no Microsoft Excel 2019 e apresentados em gráficos.

\section{RESULTADOS E ANÁLISES}

O formulário foi enviado aos alunos via internet, pois o Brasil segue as recomendações de isolamento social e as aulas presenciais na instituição haviam sido suspensas, assim, $82,5 \%$ da amostra responderam no primeiro dia, $5,8 \%$ no segundo dia e $1,7 \%$ no terceiro e quarto dia, evidenciando que a participação foi definida logo após o recebimento do endereço eletrônico do questionário.

A amostra foi composta por 126 participantes (64,2\% mulheres e $35,8 \%$ homens), na qual $47,6 \%$ possuíam entre 21 e 30 anos de idade e $73,6 \%$ se declararam brancos. Além disso, 52,4\% são alunos do curso de Tecnologia em Gestão de Recursos Humanos (GRH), enquanto 47,6\% estão matriculados em Tecnologia de Gestão Empresarial (GE).

Os participantes foram questionados a respeito de saúde e bem-estar mental e 
$73 \%$ dos estudantes sentiram alterações psicológicas e/ou no sono decorrente do estresse da atual situação pandêmica, $93 \%$ se entretêm com recursos por meio da Internet e, ainda, $68,3 \%$ declararam não estar praticando atividades físicas durante o isolamento social. Estes achados são comuns em momentos de disseminação da SARS-COV2 e também com outras doenças infecciosas como o Ebola e a gripe do H1N1 (Reardon, 2015; Shigemura et al., 2020).

As dúvidas quanto ao controle do novo coronavírus, sua acelerada disseminação, (Schmidt et al., 2020), a mudança da rotina e até nas relações familiares, são alguns dos fatores capazes de influenciar no estado emocional dos indivíduos (Brooks et al., 2020; Cluver et al., 2020).

Em relação especificamente à situação profissional, antes da pandemia, $61 \%$ dos alunos afirmaram trabalhar com registro profissional na Carteira de Trabalho e Previdência Social (CTPS), dentre os entrevistados $21 \%$ estavam desempregados antes da pandemia, $12 \%$ trabalhavam sem vínculo empregatícios e $5 \%$ trabalhavam em seu próprio negócio.

No primeiro quadrimestre de 2019, o Cadastro Geral de Empregados e Desempregados registrou 5.529.457 admissões e 5.215.622 demissões, com um saldo positivo de 313.835. De acordo com os dados emitidos pelo Ministério da Economia, de janeiro a abril de 2020, houve 4.999.981 admissões e 5.763.213 demissões no Brasil, resultando em um déficit de 763.232. Sendo assim, as admissões caíram 9,6\% e as demissões subiram $10,5 \%$ no intervalo de um ano.

Após o início do isolamento social para contenção da pandemia, o percentual de alunos que perderam o emprego aumentou, passando de $21 \%$ para $25 \%$. Segundo os dados do ministério da Economia, as demissões no primeiro quadrimestre de 2020 tiveram um aumento de $10 \%$ em relação ao mesmo período do ano passado, a amostra desta pesquisa ficou abaixo deste percentual, no entanto, mesmo assim é um número significativo.

Com o questionário foi possível verificar o porte das empresas que empregam os alunos entrevistados, sendo $5 \%$ de $\mathrm{MEI}, 7 \%$ de microempresa, $17 \%$ de empresas de médio porte, $31 \%$ de grandes empresas e $17 \%$ são multinacionais.

Em relação aos serviços essenciais, $57 \%$ afirmou que o seu trabalho não é considerado um serviço essencial e $43 \%$ afirmou que trabalho é sim um serviço essencial. Desses $43 \%$ que responderam que sim, $22 \%$ trabalham no setor de segurança e outros, $8 \%$ trabalham no setor da alimentação e no setor de saúde, $5 \%$ no setor de manutenção.

Dentre os trabalhadores que são prestadores de serviço, $91 \%$ declarou não atuar na área da saúde e dentre aqueles que atuam, $64 \%$ é do setor privado, $9 \%$ no serviço público, $9 \%$ no comércio de produtos de saúde e 18\% trabalham em indústrias de produtos de saúde.

Dentre os que trabalham no comércio, $38 \%$ responderam que durante a pandemia, as empresas têm efetuado vendas por meio de redes sociais e Whatsapp, $28 \%$ já vendiam por comercio eletrônico, $19 \%$ adotaram o comércio eletrônico após medidas de restrição, $6 \%$ estão se estruturando para vender via internet e apenas $9 \%$ não estão conseguindo vender. 
Os entrevistados também foram questionados sobre o impacto que a pandemia estaria causando no seu trabalho e $34 \%$ respondeu que a pandemia não causou impacto, $52 \%$ afirmou que impactou, mas continuou trabalhando e apenas $13 \%$ parou totalmente as atividades.

Em relação a adesão aos programas de auxílio emergencial do Governo Federal, os entrevistados responderam que $67 \%$ não aderiu a nenhum programa, $18 \%$ não aderiu ainda, mas vai aderir e 15\% aderiram a Medida Provisória 936.

Em relação a medidas de combate, prevenção e transmissibilidade da COVID-19, $22 \%$ dos trabalhadores indicaram que a empresa não adotou nenhum tipo de medida, mas $78 \%$ das empresas adotaram algumas medidas como o uso de máscara, álcool em gel, distanciamento nos postos de trabalho e afastamento dos funcionários do grupo de risco.

Apenas $17 \%$ dos entrevistados indicou aumento do faturamento empresarial nas atuais circunstâncias, $52 \%$ afirmou que faturamento caiu, e $32 \%$ disse que o faturamento caiu, mas com o passar do tempo e as medidas adotadas teve uma leve retomada.

Os questionamentos também envolviam a atuação em home office, $53 \%$ relatam que empresa aderiu total ou parcialmente a esta modalidade, $47 \%$ não aderiu. Dentre os que adotaram, $71 \%$ aceitaram bem essa nova modalidade e $29 \%$ não gostou de trabalhar dessa maneira.

Na opinião dos participantes, $37 \%$ acreditam que o home office não terá continuidade no ambiente profissional pós-pandemia, dos $67 \%$ que acreditam que essa modalidade continuará, $6 \%$ acreditam que será mantido, $76 \%$ acreditam que será mantido, mas deverá ser melhor estruturado e $18 \%$ acreditam que será ampliado para os demais setores.

Dentre as pessoas que não estão trabalhando atualmente, $60 \%$ aderiram ao auxílio emergencial do Governo Federal, 34\% não aderiram e 6\% afirmam que irão aderir.

Os resultados indicaram que $22 \%$ do total da amostra deste estudo afirma que solicitou o Auxílio Emergencial, e 33\% disseram que a empresa que trabalha aderiu ou irá aderir ao Benefício Emergencial de Preservação do Emprego e Renda (BEm). Para os trabalhadores de carteira assinada que tiveram seus ganhos reduzidos em função da pandemia de COVID-19, o Governo Federal disponibilizou o BEm, este benefício foi instituído por meio da Medida Provisória 936/2020 aos trabalhadores que tenham feito acordo com o empregador para redução proporcional de jornada de trabalho e de salário, ou para suspensão temporária do contrato de trabalho. Os trabalhadores informais, Microempreendedores Individuais (MEI), autônomos e desempregados tiveram o direito de solicitar o Auxílio Emergencial, que é um benefício financeiro com objetivo fornecer proteção emergencial no período de enfrentamento à crise causada pela COVID-19.

O Governo do Estado de São Paulo, dentro de sua alçada, também tem atuado fortemente com medidas de combate e controle da COVID-19. De acordo com o portal do governo do estado foi desenvolvido um plano abrangendo todos os setores, hospitais foram construídos, aquisição de equipamentos e suprimentos, medidas como o uso obrigatório de máscaras em espaços públicos, fechamento do comércio não essencial, distanciamento social e adiantamento de feriados. Estas ações foram realizadas com o intuito de desacele- 
rar do contágio da doença, tanto na capital quanto nos municípios do interior (Fonte: Portal do Governo do Estado de São Paulo).

Todas as ações indicam que a atuação do governo, nas três esferas, municipal, estadual e federal é extremamente necessária para evitar o colapso do sistema de saúde, e um impacto ainda mais profundo em nossa economia.

Estudiosos contemporâneos da Administração Científica focaram suas pesquisas no ambiente externo, uma vez que tem grande influência na produtividade de uma empresa (AHN, 2002), impactando nas estratégias de desenvolvimento de mercado e crescimento organizacional.

Quando a amostra dos estudantes preencheu o questionário, o Brasil era o terceiro país do mundo com maior número de casos confirmados (310.921 infectados), além de mais de 20 mil óbitos decorrentes da COVID-19, dados esses que causam grande preocupação quanto à saúde e impactam no desempenho dos trabalhadores (Fonte: Portal G1).

Ao serem questionados, $98 \%$ dos entrevistados afirmaram que a capacidade de inovação poderá ser o grande determinante para a manutenção das empresas durante e no período pós pandemia e as ações que mais farão diferença nas empresas é a capacidade de adaptação e inovação à nova realidade.

Sendo assim, a inovação em tempos de crise é benéfica, pois ela causa desenvolvimento e melhoria nas atividades organizacionais, resultando no aprimoramento dos processos, além disso, redução de custos e o aumento da produtividade (SANTANA, 2018).

De acordo com Chesbrough (2020), a pandemia provocou uma onda de inovações na ciência médica, nas empresas relacionadas à saúde, no setor público e até mesmo na gestão dessa crise.

Assim, a inovação é uma ferramenta da qual a organização deverá se valer para superar o cenário de crise e instabilidade, com a finalidade de mudar sua situação. Pradella (2013) ressalta a necessidade da inovação em uma organização, uma vez que as empresas que objetivam se destacar diante os concorrentes por meio desta inovação tendem a buscar mais qualidade, flexibilidade e obter maior eficiência, resultando assim em maior faturamento e consequentemente o resultado será um maior lucro.

\section{CONSIDERAÇÕES FINAIS}

A pandemia impôs a todos os seres humanos um modo de vida completamente diferente a tudo que já haviam sido submetidos neste início de século.

Todo avanço tecnológico que temos em diversas frentes e inúmeras conquistas em todas as áreas do conhecimento, no mundo inteiro, principalmente na saúde, não foram suficientes para evitar o impacto da pandemia na vida de todos, principalmente no aspecto profissional.

A COVID-19 deixou 4\% dos estudantes respondentes desempregados, $52 \%$ tiveram suas atividades profissionais alteradas, mas continuaram trabalhando, apenas $13 \%$ 
pararam totalmente suas atividades, e os reflexos desta situação, poderão ser medidos no futuro, período além do escopo deste trabalho. O faturamento reduziu em $52 \%$ das organizações que empregam os alunos, mas $32 \%$ disseram que o faturamento caiu pelo impacto das medidas, mas com o passar do tempo teve uma leve retomada. O home office foi adotado parcialmente em $53 \%$ das organizações e $71 \%$ dos estudantes aceitaram bem essa nova modalidade de trabalho.

Com relação às estratégias de vendas das empresas durante a pandemia, foi observado que $38 \%$ efetuam vendas por meio de Redes Sociais e WhatsApp, $28 \%$ já vendiam por comércio eletrônico e 19\% adotaram este tipo de venda após medidas de restrição, $6 \%$ das empresas estão se estruturando para vender via internet e $9 \%$ não estão conseguindo vender.

Os resultados deste estudo apenas confirmam que o impacto da pandemia na vida profissional de estudantes da IES analisada foram muitos e, em diversos aspectos, menores que o esperado diante de um momento tão difícil para a economia de nosso país, mas ficou evidente que as políticas públicas anteriores à pandemia já deixavam sem emprego $21 \%$ de estudantes de nível superior, que são, certamente, a parcela da população mais bem preparada para empreender, seja dentro de uma organização ou em seu próprio negócio.

O conhecimento e a educação são as ferramentas mais poderosas que uma civilização pode ter e agora, mais do que nunca, dependemos desses dois elementos para gerar ações efetivas que nos garantam uma retomada da economia.

Ficou evidente que os alunos reconhecem que a capacidade de inovação será determinante para a manutenção das empresas durante e no período Pós Pandemia, uma vez que $98 \%$ responderam a essa questão de forma positiva. E dentre as ações que farão a diferença nas empresas, $63 \%$ dos alunos entenderam que será a capacidade de adaptação à nova realidade.

O brasileiro, de acordo com o GEM (2018), é considerado um dos povos mais empreendedores do mundo, tendo a criatividade como um dos principais fatores, no entanto essa característica não foi relacionada à criação de ações que farão a diferença nas empresas nem tão pouco às características empreendedoras de seus integrantes, essa é uma questão que abre uma lacuna para pesquisa futura com o intuito de verificar se o estudo do empreendedorismo está privilegiando apenas a criação de empresas em detrimento de sua aplicação no setor público, social e principalmente em relação ao empreendedorismo corporativo, por serem $61 \%$ dos alunos desta IES empregados formais.

Finalmente, considera-se o resultado da pesquisa representativo entre os cursos, pois os percentuais foram muito próximos - 52,4 \% curso de GRH e 47,6 \% curso de GE dentre os estudantes que responderam ao questionário da FATEC São Carlos.

\section{REFERÊNCIAS}

AHN, S. Competition, innovation and productivity growth: a review of theory and evidence. OECD Economics Department Working Papers, n. 317, 2002. 
BERTERO, Carlos Osmar. Planejamento empresarial numa época de incerteza. Rev. adm. empres., São Paulo, v. 20, n. 4, p. 67-72, dez. 1980.

BRASIL. Ministério da Economia. Dados do Setor. Brasília, DF. 2020. Disponível em: <https://www. gov.br/economia/pt-br>. Acesso em: 27 mai. 2020.

BROOKS, S. K. et al. The psychological impact of quarantine and how to reduce it: rapid review of the evidence. Rapid Review. Lancet 2020; 395: 912-20. Vol 395 March 14, 2020.

CHESBROUGH, H. To recover faster from Covid-19, open up: Managerial implications from an open innovation perspective. Disponível em: <https://www.ncbi.nlm.nih.gov/pmc/articles/ PMC7161493/>. Acesso em: 24 jun 2020.

CHIAVENATO, I. Empreendedorismo: dando asas ao espírito empreendedor. $2^{\circ}$ edição. São Paulo: Saraiva, 2007.

CLUVERL, L. et al. Parenting in a time of covid-19. Disponível em <https://doi.org/10.1016/S01406736(20)30736-4>. Acesso em: 01 de junho de 2020.

Debortoli et al. Análise do mercado de trabalho a partir da percepção de pessoas desempregadas. Revista Destaques Acadêmicos, Lajeado, v. 11, n. 1, 2019.

GIL, A. C. Como elaborar projetos de pesquisa. 5. ed. São Paulo: Atlas, 2010.

Johns Hopkins University School of Medicine. Disponível em: <https://coronavirus.jhu.edu/>. Acesso em 18 jul. 2020.

GEM. Empreendedorismo no Brasil. Relatório Executivo 2018. Disponível em: <http://ibqp.org. br/PDF\%20GEM/Relat\%C3\%B3rio\%20Executivo\%20-\%20Brasil\%202018\%20-\%20web.pdf>. Acesso em: 01 jul. 2020.

MATOS, S.; MIRANDA, L. Em Foco IBRE: Cenários para o crescimento para o PIB do Brasil em 2020. IBRE. Boletim Macro, março, 2020.

Parmet, W. E.; Sinha, M.S. Covid-19 -The law and limits of quarantine. N Engl J Med. Abril de 2020. Disponível em: <https://doi.org/10.1056/NEJMp2004211>. Acesso em: 11 jun. 2020.

PORTAL G1. Casos de Coronavírus e número de mortes no Brasil em 21 de maio. Disponível em: <https://g1.globo.com/bemestar/coronavirus/noticia/2020/05/21/casos-de-coronavirus-e-numerode-mortes-no-brasil-em-21-de-maio.ghtml>. Acesso em: 01 jun. 2020.

PORTAL G1. Pedidos de seguro-desemprego aumentam $76,2 \%$ na parcial de maio, diz governo. Disponível em: <https://g1.globo.com/economia/noticia/2020/05/21/pedidos-de-segurodesemprego-aumentam-762percent-na-parcial-de-maio-diz-governo.ghtml $>$. Acesso em: $01 \mathrm{de}$ jun. 2020.

PRADELLA, S. Gestão de processos: uma metodologia redesenhada para a busca de maior eficiência e eficácia organizacional. Revista Gestão \& Tecnologia, Pedro Leopoldo, v. 13, n. 2, p. 94-121, mai./ago. 2013.

REARDON, S. Ebola's mental-health wounds linger in Africa. News in Focus. Nature, v. 519, p. 13-14. 2015. Disponível em: <https://www.nature.com/news/ebola-s-mental-health-wounds-lingerin-africa-1.17033> Acesso em: 29 mai. 2020.

SANTANA, G. A. et al. Adoção de inovações de processos em período de crise pelas empresas de Petrolina-PE. Revista Navus, Florianópolis, v.8, n.4, p. 167-179, out./dez. 2018.

SÃO PAULO. Governo Estadual de São Paulo. Saiba quais as medidas do Governo de SP para o combate ao Coronavírus. Disponível em: <https://www.saopaulo.sp.gov.br/spnoticias/saiba-quaisas-medidas-do-governo-de-sp-para-o-combate-ao-coronavirus-2/>. Acesso em: 30 mai. 2020. 
SÃO PAULO. Portal Centro Paula Souza. São Paulo, SP. 2020. Disponível: <http://www.portal.cps. sp.gov.br/fatec/escolas/>. Acesso em: 25 mai. 2020.

SARTI, T. D. et al. Qual o papel da Atenção Primária à Saúde diante da pandemia provocada pela COVID-19?. Epidemiol. Serv. Saúde, Brasília, v. 29, n. 2. 2020.

SCHMIDT, B. et al. Saúde mental e intervenções psicológicas diante da pandemia do novo coronavírus (COVID-19). Estud. psicol. (Campinas), Campinas, v. 37, e200063, 2020.

Shigemura, J.; Morganstein, J. C. Public responses to the novel 2019 coronavirus (2019$\mathrm{nCoV}$ ) in Japan: Mental health consequences and target populations. Psychiatry and Clinical Neurosciences, Washington: p. 277-283. 2020.

World Health Organization. Coronavirus disease (COVID-2019): situation report 72. Genebra: World Health Organization. 2020. Disponível em: <https://www.who.int/docs/default-source/ coronaviruse/situation-reports/20200401-sitrep-72-covid-19.pdf?sfvrsn=3dd8971b 2>. Acesso em: 03 jun. 2020. 


\section{Organizadora}

\section{Andreia Antunes da Luz}

Possui doutorado em Engenharia de Produção pela Universidade Tecnológica Federal do Paraná (2017), graduação em Administração pela Universidade Estadual de Ponta Grossa (2006) e mestrado em Engenharia de Produção pela Universidade Tecnológica Federal do Paraná (2012). Atualmente é professora da Faculdade Sagrada Família. Tem experiência na área de Administração, com ênfase em Administração de Empresas, atuando principalmente nos seguintes temas: transferência de tecnologia, incubadoras de empresas de base tecnológica, parque tecnológico, empreendedorismo e gestão do conhecimento. 


\section{Índice Remissivo}

A

AHP 7, 8, 9, 11, 12, 13, 14, 16, 18

Anais 58, 59

B

Bibliométrica 35, 36, 44

C

Circular 58, 59, 61, 62, 66, 67, 68, 69, 70

Classificação 8, 9, 10,11,12,13, 14, 15, 16, 18

Clusters 35, 37, 39, 41, 43

Cocitação 35, 41, 42

Competitividade 36, 59, 60, 61, 67

COVID-19 60, 67, 71, 72, 73, 74, 77, 78, 81

Crise $74,77,78,80$

Criticidade 8, 9, 10, 11, 14, 15, 16

Curso superior 73

Curva $\mathrm{ABC} 8,9,14$

D

DBR 35, 36, 38, 39, 40, 41, 42, 43, 44, 45

Drum-buffer-rope $35,39,43,44,45$

DSR $11,12,18$

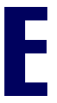

Economia $21,36,59,60,61,62,66,67,68,69,70,74,78,79,80$

Economia circular 59, 62, 67, 68, 69, 70

Econômico 20, 21, 22, 25, 26, 27, 28, 30, 31, 32, 33, 50, 59, 60, 62, 66, 68, 74

Eficiência 21, 24, 25, 27, 28, 29, 30, 78, 80

Emprego 72, 76, 79

Empresa 8, 9, 11, 12, 13, 14, 15, 18, 51, 60, 61, 63, 64, 65, 66, 68, 69, 74, 77, 78

Estoque $7,8,9,10,11,12,13,14,17,18,36$

Estudantes $63,71,72,73,76,78,79$

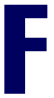

Ferramenta $10,50,51,53,78$

Fronteira 20, 21, 31, 69

Indústria 66

Inovação $49,50,56,58,59,60,61,62,63,64,67,68,69,72,74,75,78,79$

Inovação aberta $58,59,60,62,63,64,67,68,69$

Inovações $61,64,74,78,80$

Inovadores 61, 67 
Literatura $34,35,36,37,39,41,42,43,59,65,66,67,68,69,70$

Lucro $48,49,50,51,52,53,54,55,56,66,78$

M

Maximização 48, 49, 50, 51, 52, 54

Mercado de trabalho $72,74,80$

Modelo 18, 34, 35, 39, 40, 41, 43, 49, 51, 52, 53, 54, 55, 56, 61, 62, 65, 66, 67, 68

N

Negócio 9, 11, 18, 61, 65, 70, 76, 79

0

OMS 60

Oportunidades 35,74

Organizações $36,51,59,60,61,63,64,67,74,79$

\section{D}

Pandemia 59, 60, 61, 67, 69, 71, 72, 73, 74, 75, 76, 77, 78, 79, 81

Pesquisa operacional 21, 49, 56

Pessoas 22, 32, 59, 60, 72, 73, 74, 77, 80

Possibilidades 12, 14, 20, 21, 31, 60

Preços 21

Princípios 21, 22, 31, 32, 33, 62, 65

Produção 9, 14, 15, 20, 21, 22, 23, 24, 25, 26, 27, 28, 29, 30, 31, 32, 36, 37, 39, 40, 41, 42, 49, 51, 52, 53, $54,55,59,61,63,65,66,67,69$

Produtividade $24,25,27,29,36,39,50,65,78$

Produtos 9, 10, 22, 23, 24, 25, 26, 27, 28, 30, 32, 51, 61, 62, 67, 74, 76

Professores 3

Profissional 71, 72, 73, 74, 76, 77, 78, 79

Programação linear 41, 49, 56, 57

Publicações 35, 36, 37, 38, 42, 66, 67

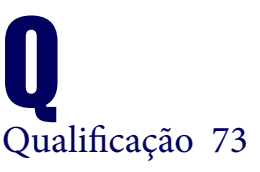

\section{$\mathbf{R}$}

Recursos 22, 26, 27, 30, 31, 36, 50, 51, 60, 61, 62, 66, 76

Revisão 35, 36, 37, 38, 42, 43, 44, 59, 65, 67, 68, 69, 70

\section{S}

Serviços 22, 61, 74, 76

SIMPEP $44,58,59,61,62,63,65,67,68,69,70$

Sistema $8,21,22,24,25,26,27,28,30,31,32,36,38,40,60,61,65,68,74,78$

Sistema de produção $21,22,25$

Sistemática 59, 67, 69, 70 
Software $35,37,41,55$

Sustentabilidade $25,33,65,66$

Sustentáveis 65,66

Tecnologias 31, 50, 61, 64, 66

Trabalho $9,14,18,24,35,36,49,50,52,53,67,72,73,74,75,76,77,79,80$

Uva $49,50,52,53,54,55,56$

V

Vantagem comparativa $21,28,30$

Vida $22,25,33,59,60,69,71,72,73,74,78,79$

Vosviewer 37, 38, 41 
<smiles>CC(C)(C)C1CC1</smiles> 